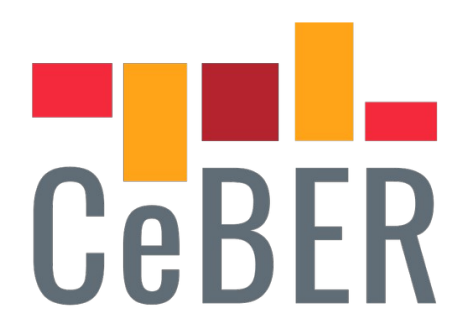

CENTRE FOR BUSINESS AND ECONOMICS RESEARCH

- UNIVERSITY OF COIMBRA

\title{
Corporate debt booms, financial constraints, and the investment nexus
}

\author{
Bruno Alexandre Ferreira Albuquerque \\ Bank of England and FEUC
}

CeBER Working Papers

No. 8 / 2021 


\title{
Corporate debt booms, financial constraints, and the investment nexus*
}

\author{
Bruno Albuquerque ${ }^{\dagger}$
}

\begin{abstract}
Does corporate debt overhang affect investment over the medium term? To uncover this association, I measure debt overhang with a concept of debt accumulation or debt boom, and combine leverage with liquid assets to capture financial constraints. Using a large US firm-level panel over 1985Q1-2019Q1, I find that debt overhang leads financially vulnerable firms to cut permanently back on investment: a 10 p.p. increase in the three-year change in the leverage ratio is associated with lower investment growth of 5 p.p. after five years compared to the most resilient firms. I also find that vulnerable firms experience weaker intangible capital growth in the aftermath of debt booms. Finally, I find that general equilibrium effects dominate, stressing the risk that firm-specific debt booms in a subset of firms may spill over to the rest of the economy.
\end{abstract}

Keywords: Corporate debt booms; Firm investment; Financial constraints; Local projections

JEL classification: D22, E22, E32, G32

\footnotetext{
${ }^{*}$ The views in this paper represent only my own and should therefore not be reported as representing the views of the Bank of England. I would like to thank my discussants, Beatriz González and Enisse Kharroubi, for insightful and constructive comments. I would also like to thank Martin Iseringhausen, Matt Waldron, Neeltje van Horen, Sarah Venables, and participants at the Bank of England brownbag seminar, the $3^{\text {rd }}$ Warsaw Money-Macro-Finance Conference, the $37^{\text {th }}$ Symposium on Money, Banking and Finance, the 2021 IAAE Annual Conference, and the CEBRA 2021 Annual Meeting for valuable comments and suggestions.

${ }^{\dagger}$ Bank of England and CfM, bruno.albuquerque@bankofengland.co.uk; 20 Moorgate, London, EC2R 6DA, United Kingdom
} 


\section{Introduction}

How does corporate debt overhang affect investment growth? This long-standing question goes back to the seminal paper by Myers (1977). His hypothesis was that a highly leveraged firm is unable to raise additional debt to finance new projects, as the profits are appropriated by existing debt holders, not potential new investors. Similarly, in the presence of default risk, there may be underinvestment in projects with positive net present value, because equity holders do not benefit in case of default. ${ }^{1}$

Several years later, the literature started to place the focus on the relationship between the level of firm leverage and investment. For instance, Lang et al. (1996), Hennessy (2004), and Hennessy et al. (2007) show empirically that leverage is negatively associated with future growth. In particular, Lang et al. (1996) find this negative association for firms whose growth opportunities are not recognised by the capital markets, or for firms that do not have good investment opportunities. Their results are consistent with the view that debt has a disciplinary role in investment decisions (Grossman and Hart 1982). Focusing on the 2007-09 Great Financial Crisis (GFC), research has also found that firms with higher pre-crisis debt experienced weaker investment in the aftermath of the GFC (Campello et al. 2010, Giroud and Mueller 2017, Buera and Karmakar 2019, Kalemli-Ozcan et al. 2019, Barbiero et al. 2020, Blickle and Santos 2020). This strand of research has mostly used firm-level data, focusing on high debt as a constraint on investment.

The concept of 'high' or 'excessive' debt is, however, a subjective concept, and potentially firm-specific. The level of debt in itself may thus not be able to capture debt imbalances adequately. In addition, financial imbalances take some time to emerge. To capture debt overhang effects, we may need to look at a concept of debt accumulation for a long period of time, rather than at the level of debt. A large number of papers has found that debt booms or debt misalignments in the private sector are associated with economic slowdowns and future recessions (Schularick and Taylor 2012, Jordà et al. 2013, 2015, 2020, Dell'Ariccia et al. 2016, Krishnamurthy and Muir 2017, Mian et al. 2017, Albuquerque 2019, Greenwood et al. 2020, Richter et al. 2021).

But two recent papers make the case that only debt booms in household debt are associated with lower medium-term growth, while fluctuations in debt in the non-financial corporate (NFC)

\footnotetext{
${ }^{1}$ When a firm defaults, the liquidation of its assets accrues first to senior creditors, then to junior creditors, and only then to equity holders.
} 
sector are not (Mian et al. 2017, Jordà et al. 2020). They measure debt overhang as long changes in the debt-to-GDP ratio, and use cross-country aggregate data for several advanced economies. Jordà et al. (2020) suggest that the unique feature and incentives of corporate debt imply that debt of firms in financial distress can normally be restructured and liquidated quickly, unlike household debt, therefore having minimal or no impact on medium-run GDP growth. These findings speak to an earlier literature on the finance-growth nexus, whereby credit deepening and the quality of financial intermediation create the conditions for faster investment and economic growth (King and Levine 1993, Levine 2005, Rancière et al. 2008, Beck et al. 2012).

Overall, we are left wondering whether the mixed results in the literature on the effect of corporate debt overhang on investment are due to: the nature of the data, aggregate versus firm-level; or/and to the indicator of debt overhangs, level of debt or long changes in debt ratios. I argue that we need to merge both strands of the literature to improve our understanding about the association between corporate debt overhangs and future investment.

This paper contributes to the literature on debt cycles and economic activity by revisiting the corporate debt-investment nexus in a large quarterly panel of US firms from Compustat. This paper is closest in spirit to Mian et al. (2017), Blickle and Santos (2020), and Jordà et al. (2020), who study how corporate debt overhangs in the corporate sector transmit to the real economy. Using a concept of a debt boom or debt build-ups at the firm level, my main finding suggests that corporate debt overhang is associated with weaker future investment growth over the medium term. I show that financially constrained firms drive the results, in line with models with financial constraints that predict that borrowing constraints prevent firms to finance investment spending when the rise in debt becomes unsustainable.

Throughout the paper I make the case for using four key ingredients in the empirical framework. First, I use micro-level data for a large panel of listed US non-financial firms to account for the substantial firm heterogeneity in corporate balance sheets. Studies that use cross-country aggregate data may mask important relationships between debt overhang and investment (Beck et al. 2012, Mian et al. 2017, Jordà et al. 2020). Not accounting for firm heterogeneity may potentially bias the coefficients towards zero as the micro effects are washed away.

Second, I use data since the mid-80s that span several episodes of firm-specific debt build-ups. This allows me to overcome the challenge of extrapolating findings that focus on a particular episode, such as the GFC. The association between corporate debt and investment during the GFC may be plagued by important confounding effects, such as low bank capital and household 
deleveraging effects. This suggests that we should look at previous episodes of debt build-ups.

Third, I measure debt overhang through a concept of debt booms or debt build-ups by taking the accumulation of debt relative to assets over the preceding three years. ${ }^{2}$ This variable does not make a judgement about the level of debt per se, but instead identifies the emergence of debt booms or debt misalignments that sow the seeds of damaging and costly financial crises (Kindleberger 1978, Schularick and Taylor 2012, Jordà et al. 2013, 2015).

Fourth, I combine leverage and liquid assets to better capture financially constrained firms in the data. While leverage seems to be a popular proxy in the literature, there is not yet a consensus on which observables better identify constrained firms (Farre-Mensa and Ljungqvist 2016, Melcangi 2019). For instance, a firm with high debt may have a healthy balance sheet as reflected in high liquid asset holdings and high profits, and can thus take on more debt to finance future investment projects. Rather than using leverage or liquid assets in isolation, I show that we get a better proxy for financial constraints when looking at highly indebted firms and with limited liquid assets - firms that I label vulnerable. Specifically, vulnerable firms belong simultaneously to the top tertile of the leverage ratio, and to the bottom tertile of the net liquid asset ratio.

I study how investment growth evolves in the aftermath of debt build-ups by using Jordà (2005)'s Local Projections on a large panel data set of US non-financial firms over 1985Q12019Q1. I interact the debt overhang variable with a dummy variable that captures whether a firm is financially constrained to allow for heterogeneous effects of firm-specific debt booms on investment.

My main findings are as follows. First, I provide evidence that corporate debt booms are associated with weaker future investment over the medium term. I find that the negative association between debt and investment is driven by financially vulnerable (constrained) firms. Relative to a scenario of no debt boom, my estimates suggest that a 10 percentage point (p.p.) increase in debt build-ups for these constrained firms is associated with weaker investment of $3.4 \%$ after five years. For the same 10 p.p. increase in the pace of debt accumulation, constrained firms experience lower investment growth of roughly 2.5 p.p. compared to unconstrained firms. Using corporate bond yields from TRACE, I offer some evidence that debt build-ups in vulnerable firms are also associated with a larger and statistically significant increase in borrowing costs relative to non-vulnerable firms. This highlights the role that financial constraints may

\footnotetext{
${ }^{2}$ I use the terms debt build-ups and debt booms interchangeably.
} 
have in amplifying the negative effects of a debt boom through higher borrowing costs (Blickle and Santos 2020, Ebsim et al. 2020). Constrained firms arguably face higher (re-)financing costs and therefore tighter credit conditions, which ultimately 'force' them to cut back on investment spending when a debt boom becomes excessive or unsustainable relative to a firm's assets. Moreover, using estimates of intangible assets from Eisfeldt et al. (2020), I find that debt booms in financially vulnerable firms are associated not only with weaker future capex growth, but also with weaker intangible capital growth. This result is suggestive of an important negative debt overhang effect which prevents financially constrained firms from financing their investment, both in fixed assets and intangible assets.

Second, within unconstrained firms, I find that firms with low debt and high liquid asset experience increases in investment in the aftermath of debt build-ups. This result suggests that we are in the presence of 'Resilient' firms with high financial flexibility whose debt accumulation allows them to finance investment (Fahlenbrach et al. 2020). From a different angle, it seems that capital markets do not penalise firms by taking on new debt as long as their balance sheet is perceived as being healthy: high liquid assets and low outstanding debt. This finding is in line with models that predict a positive link between leverage and investment, as long as a crisis does not occur (Rancière et al. 2008). Overall, I find a large and statistically significant difference in the investment behaviour between vulnerable and resilient firms: for every 10 p.p. increase in debt build-ups, investment growth of vulnerable firms is 5 p.p. lower after five years.

Third, the source of financing matters. I find that build-ups in bank loans for vulnerable firms appear to be associated with larger declines in investment than build-ups originated in market debt. My results suggest that the source of the debt build-up, after controlling for the share of bank debt in total debt, is indicative of larger investment cuts in the aftermath of a debt boom. This is a novel result in the literature that complements the view that firms that rely on bank debt to finance investment projects are more exposed to credit supply shocks (Kashyap et al. 1993, Becker and Ivashina 2014).

Fourth, using quantile panel regressions (Machado and Santos Silva 2019, Jordà et al. 2020, Adrian et al. 2021), I find that corporate debt booms affect more the left tail of the investment growth distribution. This suggests that debt booms amplify downside risks to the real economy (Aikman et al. 2019, Adrian et al. 2021).

Finally, I use the new method developed by Sarto (2018), and Mian et al. (2019), to estimate general equilibrium effects. This method involves essentially the comparison of coefficients from 
a regression at the firm level with industry-by-time fixed effects with another regression at the industry level with time fixed effects. I find that general equilibrium effects are very important, accounting for roughly $90 \%$ of the total effect of debt booms on investment. This highlights the role that spillovers between firms may have in amplifying partial equilibrium effects of debt booms at the firm-level.

My main findings remain robust to: (i) using alternative measures of financial constraints, such as the Hoberg and Maksimovic (2015) index, and to a lesser extent firm age (Bahaj et al. 2019, Cloyne et al. 2019, Durante et al. 2020); (ii) adding more controls variables; (iii) allowing for more persistent debt booms; (iv) using alternative definitions of vulnerable firms; (v) controlling for industry-specific shocks; and (vi) to excluding the GFC.

The rest of the paper is organised as follows. In Section 2 I look at some stylised facts about the US aggregate corporate credit cycle, and in Section 3 I describe the firm-level Compustat data. In Section $4 \mathrm{I}$ discuss the econometric approach. I present my main results on the relationship between corporate debt booms and investment in Section 5. I run panel quantile panel regressions in Section 6 to explore how debt booms affect the distribution of investment growth. In Section 7 I estimate general equilibrium effects from firm-level debt booms. Section 8 includes a battery of robustness checks. Section 9 concludes the paper. The Online Appendix includes additional figures, replicates some of the main regressions at the industry level, and carries out an exercise focused around the GFC.

\section{Corporate debt cycles}

Even before the COVID-19 shock struck the world economy in March 2020, concerns about the sustainability of the US corporate debt cycle had already been in the radar of the media and policymakers alike. ${ }^{3}$ The corporate sector had been accumulating debt - debt securities and loans - at a rapid pace since the end of 2010 , leading to a record-high debt of $47 \%$ relative to GDP at the end of 2019 (left panel of Figure 1). The fast leveraging process in the NFC sector was presumably supported by increasing risk appetite and loose financial conditions, amid an environment of low interest rates.

The large swings in corporate debt over the past 15 years - deleveraging after the GFC and debt build-up afterwards - are not a unique feature of the most recent cycle; in fact, they

\footnotetext{
${ }^{3}$ See, for instance, reports by the International Monetary Fund, the Federal Reserve, and media articles in The Economist and Financial Times.
} 
are a common pattern of business cycles over the past 40 years. Leverage typically spikes just before or during a recession, and then declines substantially. This was particularly evident in the run-up to past US recessions since the early 90s: the accumulation of debt at a significant stronger pace than GDP over the preceding three years had opened up a considerable debt gap in the NFC sector (right panel of Figure 1). The debt build-up variable is highly correlated with the debt gap, measured as the cyclical component of the debt ratio, suggesting that both indicators proxy debt imbalances. ${ }^{4}$

Figure 1: Corporate debt imbalances
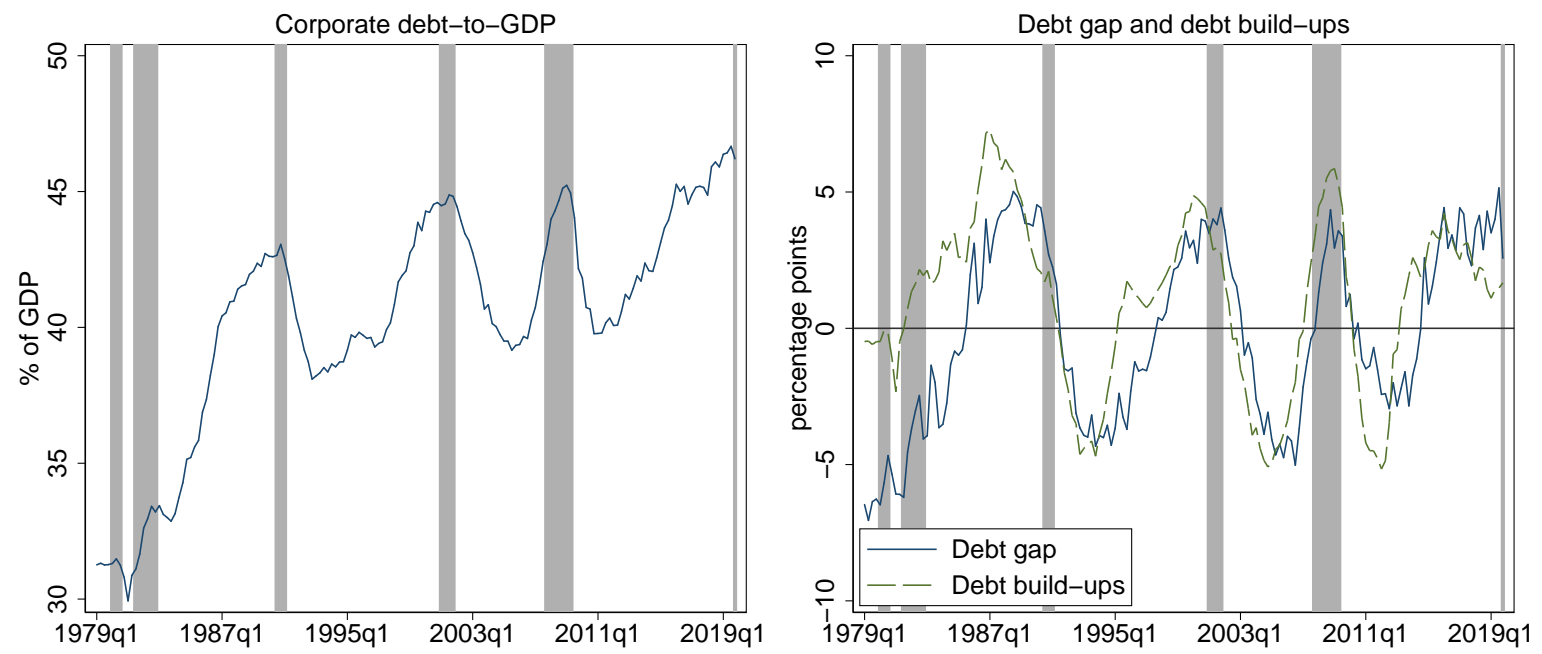

Sources: Bureau of Economic Analysis, Flow of Funds, and author's calculations.

Notes: The left panel shows the sum of debt securities and loans of the non-financial corporate business divided by GDP. The right panel shows corporate debt build-ups computed by taking the three-year change in the corporate debt-to-GDP ratio; the debt gap plots the cyclical component of the Hamilton (2018) filter. The shaded area indicates recessions as defined by the NBER.

The question is whether these debt cycles may amplify business cycles through the direct impact on investment. ${ }^{5}$ A quick look at aggregate data for the US economy seems to point in the direction of corporate debt cycles and investment cycles going hand-in-hand: debt booms typically coincide with investment growth slowdowns (Figure 2). The univariate correlation

\footnotetext{
${ }^{4}$ I detrend the non-stationary debt-to-GDP ratio with the Hamilton (2018) filter. This approach overcomes the typical issues associated with the HP filter, namely the spurious dynamic relations with no basis in the underlying data generating process, and the end-of-sample issue. The Hamilton method translates into regressing a given non-stationary variable at $t+h$ on a constant and on the four most recent values of the dependent variable available at time $t$. To capture the long cycles in debt, I set the forecasting horizon at $h=20$ quarters.

${ }^{5}$ The literature has found that household debt build-ups are associated with large consumption cuts and economic slowdowns, and raise the probability of a financial crisis ahead (Mian and Sufi 2010, 2011, Schularick and Taylor 2012, Jordà et al. 2013, 2015, Dell'Ariccia et al. 2016, Albuquerque and Krustev 2018). Research has focused predominantly on the household sector on two main grounds. First, the household sector was the natural place for researchers to start uncovering the relationship between debt and economic activity given the central role household debt played during the GFC: unprecedented run-up in debt that forced households to default or to delever significantly and cut consumption (Mian and Sufi 2010, 2011). Second, the strong rise in private debt in several Western countries in the second half of the twentieth century appears to have been driven mainly by mortgage debt (Jordà et al. 2015). At first glance corporate debt worldwide seems to have gone through much smoother cycles over the last decades. This created the notion that research should look primarely at the household sector to understand how fluctuations in private credit determine business cycles.
} 
between debt booms and investment is particularly high over the past 20 years (correlation of -0.66). The average path of investment growth during corporate debt booms can illustrate this relationship further. I identify debt booms as periods when the three-year change in the corporate debt ratio is above its sample standard deviation. This approach is similar to the one used in Richter et al. (2021), who use the Hamilton filter to look at the cyclical component of debt. In Figure 3 I plot the average path of the debt build-up variable, and of investment growth. It is striking to observe that investment growth starts to slow down roughly two years before the debt boom reaches its peak - the zero in the x-axis - and only starts to recover one year after the peak. Although I am silent on causal effects, the evidence here is suggestive of long and protracted build-ups of debt imbalances being associated with a decline in investment several quarters before the debt boom comes to an end.

Figure 2: Investment growth and corporate debt build-ups

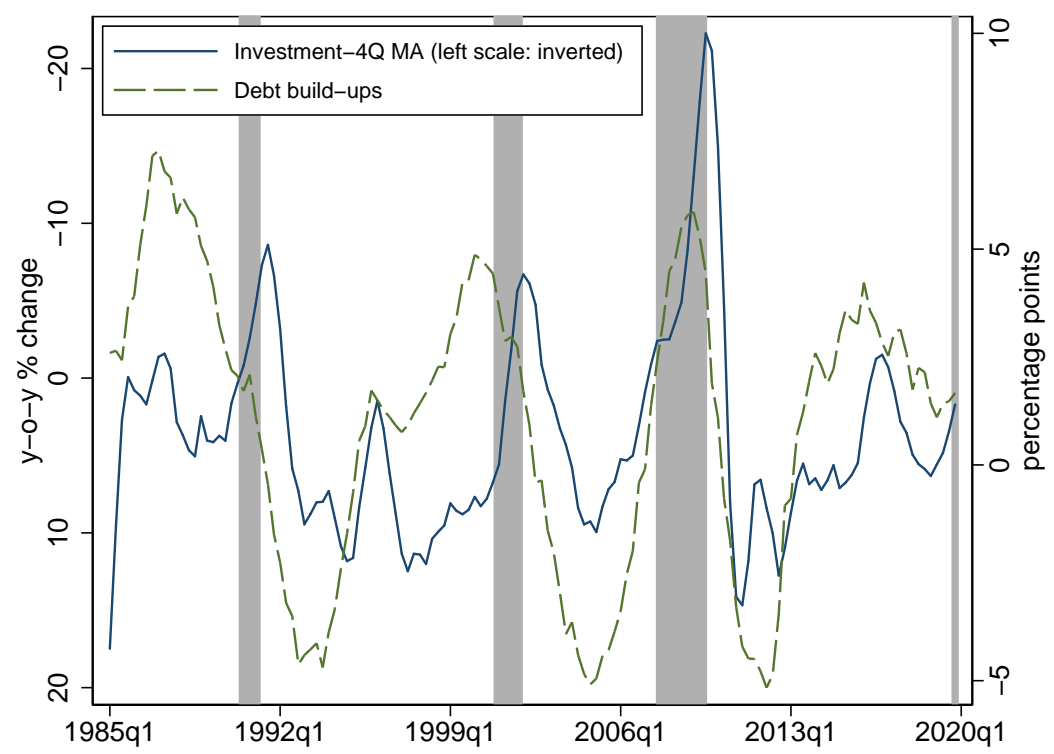

Sources: Bureau of Economic Analysis, Flow of Funds, and author's calculations.

Notes: Investment growth refers to the year-on-year percentage change in the four-quarter moving average of real gross private domestic investment from the National Income and Product Accounts. The $\mathrm{y}$-axis for investment is inverted. I compute debt build-ups by taking the three-year change in the corporate debt-to-GDP ratio. The shaded area indicates recessions as defined by the NBER.

In Figure 4 I look at price variables, measured with the Moody's Baa spread relative to the ten-year Treasury yield, and with the excess bond premium (EBP) from Gilchrist and Zakrajšek (2012). ${ }^{6}$ I find that corporate spreads tend to be low before the debt boom reaches its peak, starting to rise faster once the debt boom reaches its peak. Low corporate spreads during debt booms is in line with the notion that debt booms fuelled by expansions in the supply side of credit are a precursor to financial crises (Kindleberger 1978, Schularick and Taylor 2012, Jordà

\footnotetext{
${ }^{6}$ The EBP is a measure of investor sentiment or risk appetite in the corporate bond market that is not directly attributable to expected default risk. The EBP is defined as the spread between the rate of return on corporate securities and a similar maturity government bond rate that is left after removing the default risk component.
} 
Figure 3: Average path of debt build-ups and investment around corporate debt booms
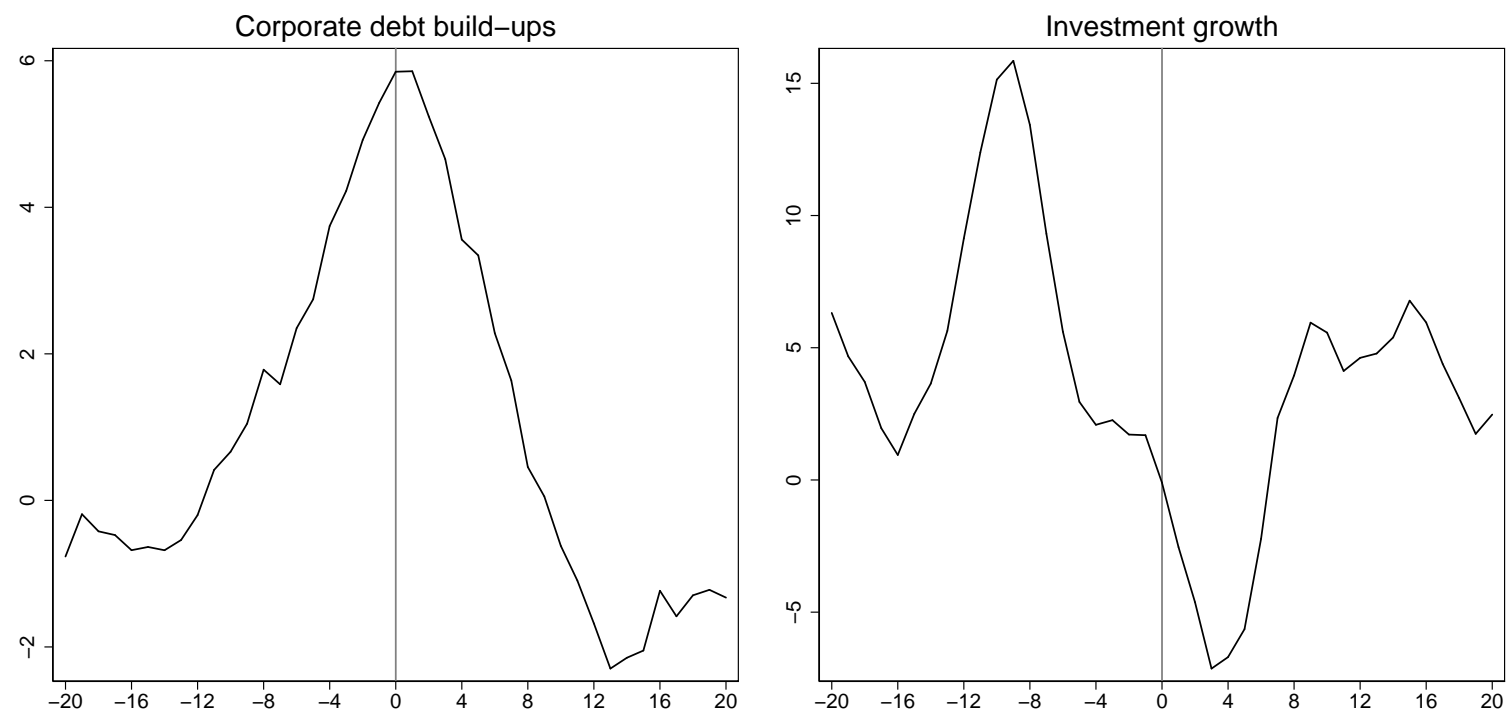

Sources: Bureau of Economic Analysis, Flow of Funds, and author's calculations.

Notes: Average path of the three-year change in corporate debt to GDP ratio and investment growth around episodes of corporate debt booms. The $\mathrm{x}$-axis shows quarters before and after the peak in the debt boom.

et al. 2013, 2015, Dell'Ariccia et al. 2016, Krishnamurthy and Muir 2017, Greenwood et al. 2020). In addition, Greenwood and Hanson (2013) uncover another central feature of the debt cycle: credit expansions are followed by a deterioration in the average quality of corporate debt issuers, adding some more evidence that credit supply expansions may be behind the emergence of corporate debt booms. Although the evidence here is not definitive - and is beyond the scope of the paper - debt accumulation by firms for a long period of time seem to be driven by credit supply shocks.

The analysis so far has relied on univariate correlations from US aggregate data, which only provide a partial picture of the relationship between debt and investment. In the rest of the paper I will use firm-level data to better inspect how investment growth evolves in the aftermath of debt booms in the corporate sector.

\section{Firm-level data}

While aggregate data are informative to track trends and discern patterns, I argue in this paper that using more granular data is key to accounting for the significant heterogeneity across firms. Specifically, I use quarterly data from Compustat (Wharton Research Data Services) with balance sheet information on US non-financial listed companies. I exclude firms in the 'Finance, Insurance and Real Estate' sectors, and make some other adjustments to the sample, 
Figure 4: Average path of corporate credit spreads around corporate debt booms
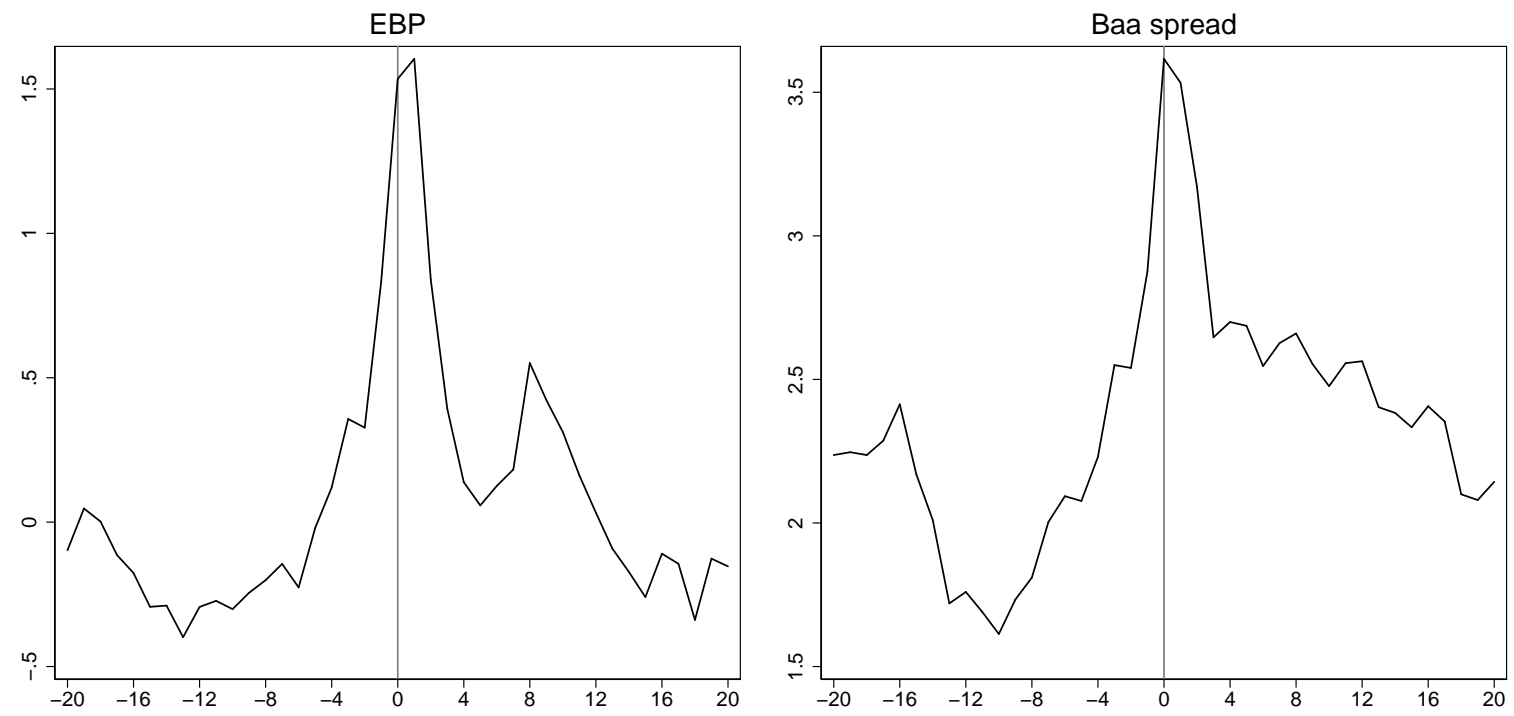

Sources: Bureau of Economic Analysis, Flow of Funds, and author's calculations.

Notes: Average path of Gilchrist and Zakrajšek (2012)'s EBP and of the Moody's Baa corporate bond yield relative to the ten-year treasury constant maturity yield around episodes of corporate debt booms. The x-axis shows quarters before and after the peak in the debt boom.

in line with standard practice in the literature (see Appendix A for the details). My final sample covers an unbalanced panel of 4,742 distinct non-financial firms over 1985q1-2019q1, resulting in 246,835 firm-quarter observations (Tables A.2 and A.3 in Appendix A show variable definitions and descriptive statistics). I deflate nominal variables with the national Consumer Price Index for All Urban Consumers (CPI-U).

To zoom in on the heterogeneity across firms, I first split firms into three equal bins of leverage and liquidity at each point in time. I measure leverage with the book value of total debt (short plus long term), and liquidity with current assets (cash and short-term investments, receivables, inventories, and other current assets) net of current liabilities (short-term debt, accounts payable, income taxes payable, and other current liabilities). I show both indicators as a fraction of total assets. I define firms with low debt/liquid assets as those belonging to the first tertile of the respective sample distribution, firms with moderate debt/liquidity to the second tertile, and firms with high debt/liquidity to the third tertile.

The first three rows of Table 1 show that firms with high debt are typically larger - as measured by median total real assets in 2009 USD - have limited liquid assets, and record the lowest capital spending growth in the sample. High-debt firms also appear to be associated with higher default risk, as reflected in the lowest interest coverage ratio (ICR) - the ratio of EBIT (earnings before interest, and taxes) to interest expenses (Palomino et al. 2019). ${ }^{7}$ In the

\footnotetext{
${ }^{7}$ The ICR measures the ability of a company to service its debt with internal cash flows.
} 
middle panel I split the sample by liquid asset holdings: firms with greater liquid asset holdings tend to be smaller, with low leverage relative to their assets, tend to invest more than other firms, and seem to be more financially resilient, as indicated by a higher ICR.

Table 1: Descriptive statistics (median values)

\begin{tabular}{|c|c|c|c|c|c|c|}
\hline & & Size & Leverage & Liquidity & $\Delta \log ($ capex $)$ & ICR \\
\hline \multirow{3}{*}{ Leverage } & Low & 93.15 & 0.01 & 0.38 & 9.31 & 20.26 \\
\hline & Moderate & 451.62 & 0.23 & 0.17 & 6.06 & 5.44 \\
\hline & High & 507.32 & 0.43 & 0.07 & 4.16 & 2.06 \\
\hline \multirow{3}{*}{ Liquidity } & Low & 944.49 & 0.33 & 0.00 & 4.09 & 2.98 \\
\hline & Moderate & 330.77 & 0.23 & 0.20 & 6.05 & 4.62 \\
\hline & High & 87.94 & 0.06 & 0.47 & 10.00 & 7.00 \\
\hline \multirow{3}{*}{$\begin{array}{l}\text { Debt to liquid } \\
\text { assets }\end{array}$} & Low & 179.62 & 0.09 & 0.00 & 6.16 & 3.37 \\
\hline & Moderate & 160.51 & 0.14 & 0.34 & 8.09 & 7.92 \\
\hline & High & 609.08 & 0.34 & 0.10 & 4.88 & 2.94 \\
\hline
\end{tabular}

Notes: Size refers to total real assets in 2009 USD, leverage to the ratio of short-term and longterm debt to total assets, liquidity to the ratio of net current assets to total assets, capex to capital spending, and ICR to the ratio of EBIT to interest expenses.

In the last rows, I combine leverage with liquid asset holdings, and split the sample into three bins of the debt-to-liquid asset ratio. Firms with high debt relative to liquid asset holdings are large, have substantial leverage, hold moderate levels of liquid assets, and have the lowest ICR. In turn, while firms with low debt relative to liquid assets appear to have healthier balance sheets, as seen in low leverage levels and moderate ICRs, the typical firm in this bucket does not hold any positive amount of net liquid assets.

I also find substantial cross sectional and time variation in the debt accumulation dynamics. The left panel of Figure 5 shows that the typical highly indebted firm has experienced large swings in debt build-ups over the last decades: the pace of debt accumulation increases substantially in the run-up to recessions, but then declines as deleveraging takes place and as the economy slows down. By contrast, firms with low debt have a rather stable debt-to-asset ratio. The right panel shows that firms holding a greater share of liquid assets have barely recorded a debt boom.

\section{Econometric framework}

I make the case for using four key ingredients in the empirical framework to better uncover the association between corporate debt booms and investment spending. First, I use micro-level data on a panel of non-financial firms to account for the heterogeneity in corporate balance 
Figure 5: Corporate debt build-ups for leverage and liquidity groups
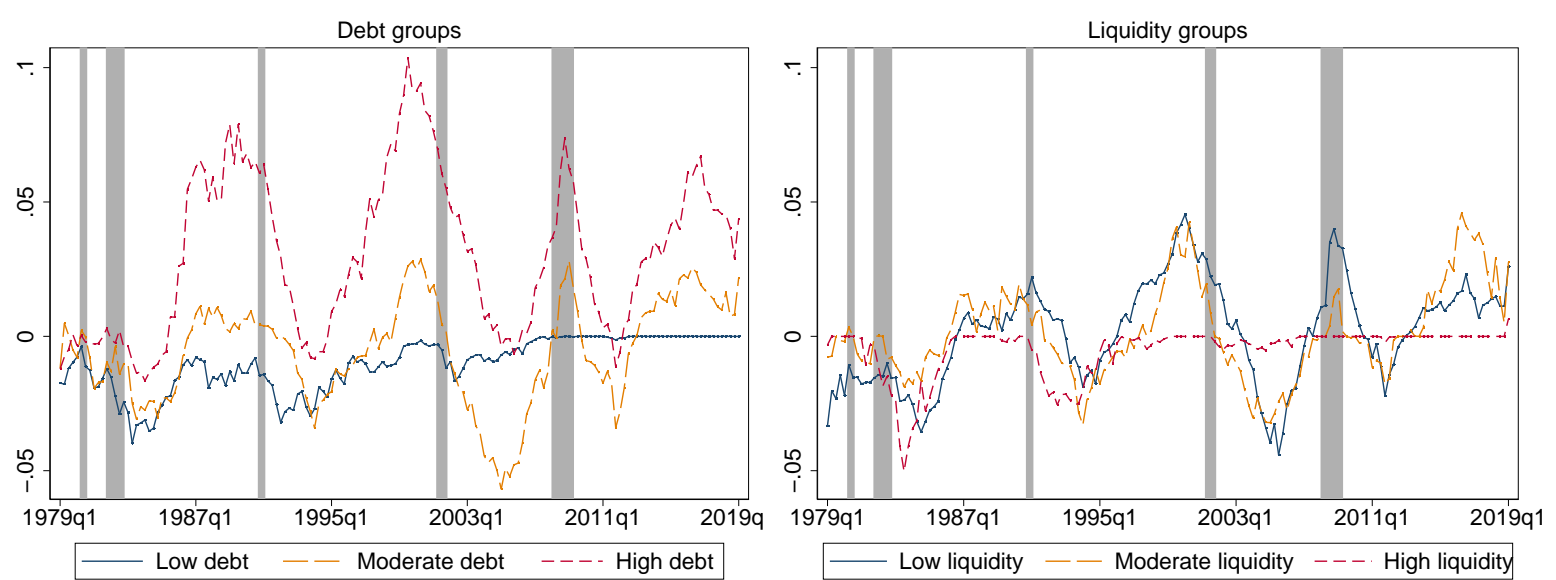

Sources: Compustat, and author's calculations.

Notes: Debt build-ups take the three-year change in the corporate debt-to-asset ratio. Low debt (liquidity) refers to the first tertile of the ratio of debt (net current asset) to total assets distribution, moderate debt (liquidity) to the second tertile, and high debt (liquidity) to the top tertile. The shaded area indicates recessions as defined by the NBER.

sheets across firms. Studies that use cross-country aggregate data, such as Beck et al. (2012), Mian et al. (2017) and Jordà et al. (2020) may mask important relationships between corporate debt booms and investment, potentially biasing the coefficients towards zero as the micro effects are washed away.

Second, I use data since the mid-80s that span several episodes of firm-specific debt buildups. This allows me to overcome the challenge of extrapolating findings from a particular episode, such as the GFC (Campello et al. 2010, Giroud and Mueller 2017, Buera and Karmakar 2019, Kalemli-Ozcan et al. 2019, Barbiero et al. 2020, Blickle and Santos 2020). For instance, the association between corporate debt and investment during the GFC may be plagued by important confounding effects, such as low bank capital and household deleveraging effects. In fact, the decline in investment we see in the data around this period may reflect other factors than just debt overhang: impaired banks had to cut credit supply to meet capital requirements. This suggests that we should look at previous episodes of debt build-ups.

Third, I take the accumulation of debt relative to assets over the preceding three years (12 quarters) as the measure of debt booms or debt build-ups. This variable captures sustained increases in debt over a specific period of time; it does not make a judgement about the level of debt per se, whether it is excessive or high, but instead identifies the emergence of debt booms or debt misalignments that sow the seeds of damaging and costly financial crises (Kindleberger 1978, Schularick and Taylor 2012, Jordà et al. 2013, 2015). Using the cumulative change in the debt ratio instead of the level of debt-to-assets or the first difference in the ratio allows the 
researcher to take into account the slow-moving properties of the debt variable, since financial imbalances take some time to emerge (Schularick and Taylor 2012, Jordà et al. 2013, 2015, 2020, Dell'Ariccia et al. 2016, Krishnamurthy and Muir 2017, Mian et al. 2017, Greenwood et al. 2020). ${ }^{8}$ In addition, the relatively large window of three years reduces the risk of capturing short-run fluctuations in the debt ratio due to the need to rollover existing debt, or due to other normal day-to-day operational decisions.

Fourth, I combine leverage and liquid assets to better capture financially constrained firms in the data. In Section 5.2 I will show empirically that it is challenging to use leverage or liquid assets in isolation to explain why some firms cut investment spending more than other firms in the aftermath of a debt boom (a similar point made by Jeenas 2019, in the context of a monetary policy shock). For instance, it is perfectly possible that a firm with high debt has a healthy balance sheet, and can thus take on more debt to finance future investment projects. High debt can, for instance, also be matched by considerable liquidity levels and high profits that make debt not that relevant as a proxy for borrowing constraints. By the same token, firms may choose higher liquidity because they may be credit constrained or for precautionary reasons (Bacchetta et al. 2019, Melcangi 2019, Cunha and Pollet 2020). I will argue that financial constraints are better captured by combining high levels of debt with limited liquid assets.

Armed with these four key ingredients, I revisit the relationship between corporate debt build-ups and investment spending in a large panel of US firms. I regress capital expenditures (capex) on debt build-ups and firm fundamentals over 1985q1-2019q1. I use Local Projections (LP) methods (Jordà 2005), which involve running separate regressions for each horizon $\mathrm{h}=0$, $1, \ldots, 20$ quarters:

$$
\Delta_{h} \log \left(I_{i, t+h}\right)=\beta^{h} \Delta_{12} \text { Debt }_{i, t-1}+\sum_{j=1}^{4} \lambda_{j}^{h} X_{i, t-j}+\eta_{i}^{h}+\zeta_{t}^{h}+\epsilon_{i, t+h},
$$

where the dependent variable $I_{i, t+h}$ is the cumulative percentage change in the logarithm of real investment spending (capex) from period $t$ to $t+h$ for firm $i, \Delta_{12} D e b t_{i, t-1}$ refers to corporate debt build-ups, measured with the 12-quarter change in the debt-to-asset ratio, and $X_{i, t-j}$ is a vector of firm-specific variables that include the debt-to-asset ratio in levels, the logarithm of real assets to proxy for the size of the firm, liquid asset holdings computed as the ratio of net current

\footnotetext{
${ }^{8}$ Other papers have used a concept of a debt gap by detrending the debt ratio from its cyclical movements (Albuquerque 2019, Richter et al. 2021). The debt gap and long changes in the debt ratio, either three-year or five-year changes, are highly correlated, as we have seen in Figure 1.
} 
assets to total assets, and lags of the dependent variable. I add these controls to minimise the possibility that the association between debt build-ups and future investment spending may be capturing other time-varying firm-specific factors. The baseline model has four lags. Fixed effects $\eta_{i}^{h}$ control for time-invariant idiosyncratic firm characteristics, and time-fixed effects $\zeta_{t}^{h}$ account for unobserved aggregate shocks. Results are robust to controlling for time-varying industry-specific shocks (see Section 8).

The key parameter of interest is $\beta^{h}$ which gives us the sensitivity of investment spending growth to debt build-ups over a five-year horizon. With the LP method, the impulse responses of investment growth at $t+h$ should be interpreted as a forecast of how investment will evolve at a given $h$ horizon when the debt build-up variable changes by one unit at time $t-1$. Although I am not interpreting here the coefficients as a causal effect of debt on investment, the fact that the debt build-up variable and a rich set of controls are all pre-determined reduces the chances that the investment behaviour after a debt build-up can be explained by other factors than debt (Jordà et al. 2020). ${ }^{9}$

I adjust standard errors with the Driscoll and Kraay (1998) estimator to account for correlation in the error term across firms and time, as the LP method with panel data usually exhibits cross-sectional and temporal dependence. This clustering method is also particularly helpful to deal with within-country correlation induced by overlapping observations from the way the corporate debt build-up variable is constructed.

\section{Main results}

\subsection{Average response}

I run regressions of Equation (1) for each horizon and plot the $\beta^{h}$ coefficients in Figure 6. I find that corporate debt build-ups are associated with weaker future investment spending over the medium term: a 10 p.p. increase in corporate debt build-ups is associated with lower investment of around 1.2\% during the subsequent five years (Figure 6). Investment tends not to recover during the five-year period, suggesting that debt booms tend to scar investment permanently. Although these results do not allow me to disentangle the mechanisms behind the negative association between debt accumulation and investment, my findings are in line with

\footnotetext{
${ }^{9}$ The regressions describe the dynamic relationship between past debt accumulations and future investment spending. The impulse responses from the local projections can be thought of as responses of investment to reduced-form innovations in debt accumulation, after controlling for a set of firm-level characteristics.
} 
the notion that the (excessive) accumulation of debt would eventually lead to a contraction in debt and lower output over the medium term, i.e. a debt overhang effect, or forced-deleveraging mechanism described in Eggertsson and Krugman (2012). In a scenario where fast build-ups in leverage may prevent firms to raise new debt to finance their activity, my results suggest that in order to avoid insolvency, a firm is left with the option of cutting investment, other costs or downsizing.

Figure 6: Impulse responses of investment spending to corporate debt build-ups

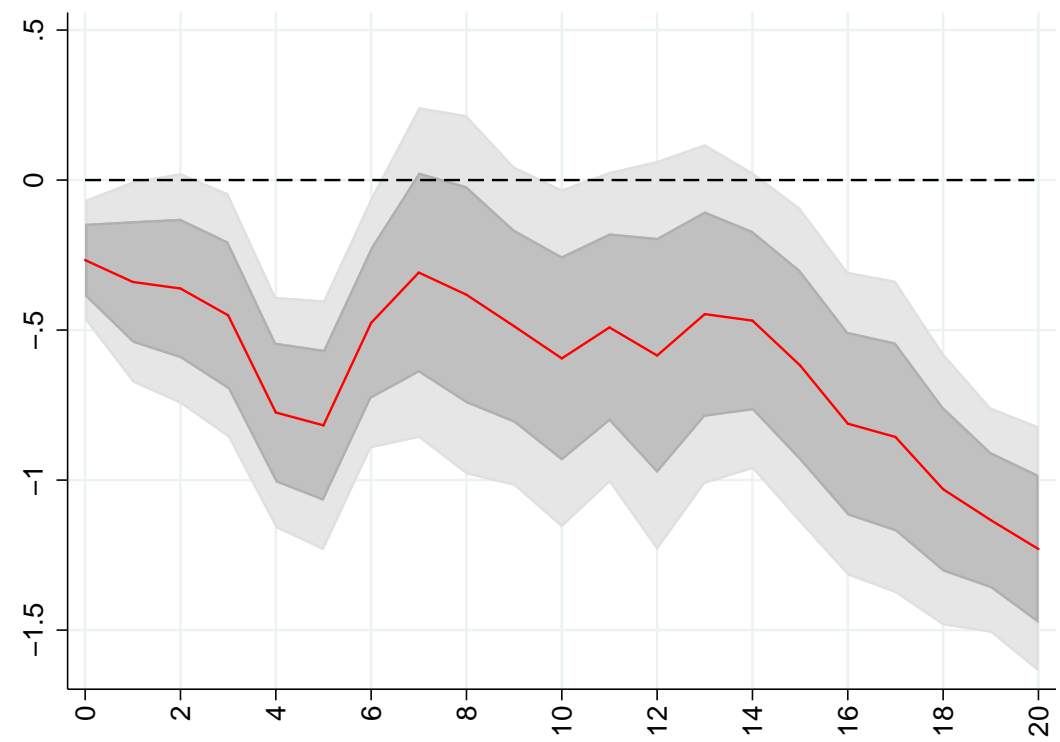

Notes: Cumulative impulse responses of capex to a 10 p.p. increase in corporate debt build-ups up to 20 quarters ahead. The dark (light) grey area refers to the 68 (90)\% confidence bands.

I re-run the same type of regression but with corporate bond yields as the dependent variable to track whether debt booms are associated with increased borrowing costs for firms. I use data from the Trade Reporting and Compliance Engine (TRACE), which provides daily transaction-level data on bond trades with information on several characteristics, including price and quantity traded. Note that TRACE data only cover market debt issuance, not bank debt. The data are available since 2002. I compute the quarterly average yield of firm $i$ by taking the volume-weighted average of the trading yield for a bond within the quarter. I am able to match 1,113 unique firms, resulting into 30,799 firm-quarter observations. This is a substantially smaller sample than the one used throughout the paper ( $13 \%$ of the main sample), making comparability regarding firm composition and time span quite challenging. With this caveat in mind, Figure D.1 in the Online Appendix shows that borrowing costs increase in the aftermath of a build-up in corporate debt (Krishnamurthy and Muir 2017).

My specification estimated on micro data points to corporate debt booms being associated with persistent investment spending contractions and higher borrowing costs. How does this 
square with the related literature? Earlier findings pointed to a link between the level of debt and lower future investment growth (Myers 1977, Lang et al. 1996, Hennessy 2004, Hennessy et al. 2007). Recent papers using micro data on US firms (Campello et al. 2010, Giroud and Mueller 2017, Blickle and Santos 2020), and on EU firms (Kalemli-Ozcan et al. 2019) have also found important debt overhang effects around the GFC: the amount of debt firms held pre-crisis - proxy for financial constraints - was associated with weaker investment during the GFC. ${ }^{10}$

The literature on predicting financial crises or recessions has found that credit booms in both the household sector and in NFCs contain relevant information for predicting the severity of a future recession (Greenwood et al. 2020). Moreover, using quantile panel regressions, Aikman et al. (2019) and Adrian et al. (2021) find that loose financial conditions coupled with rapid growth in either household or corporate debt raise downside risks to GDP growth over the medium term.

In contrast, two recent papers using cross-country aggregate data provide evidence that debt booms in the NFC sector do not seem to be associated with lower economic activity (Mian et al. 2017, Jordà et al. 2020). Mian et al. (2017) use data for 30 mostly advanced countries from 1960 to 2012, and find that only household debt build-ups predict lower GDP growth, not NFC debt. Using a panel of 17 advanced economies dating back to the $19^{\text {th }}$ century, Jordà et al. (2020) also do not find any link between corporate debt booms and lower future investment or economic growth during recessions and recoveries. Jordà et al. (2020) argue that the unique feature and incentives of corporate debt imply that debt of firms in financial distress can normally be restructured and liquidated quickly, unlike household debt, therefore having minimal or no impact on medium-run GDP growth. These two papers seem more aligned with an earlier literature on the finance-growth nexus: there is an investment channel through which credit deepening and the quality of financial intermediation is associated with faster economic growth (King and Levine 1993, Levine 2005, Rancière et al. 2008, Beck et al. 2012). The argument is that financialisation stimulates economic growth by increasing the rate of capital accumulation and by improving the efficiency with which economies use that capital (King and Levine 1993). For instance, using cross-country growth regressions over 1994-2005, Beck et al. (2012) argue

\footnotetext{
${ }^{10}$ A large number of papers has looked at the role of debt in the transmission of monetary policy to investment using firm-level data. On the one hand, there is evidence that investment of credit-constrained firms is more responsive to monetary policy, alluding to Bernanke and Gertler (1995)'s financial accelerator theory (Bahaj et al. 2019, Cloyne et al. 2019, Jeenas 2019, Anderson and Cesa-Bianchi 2020, Durante et al. 2020). But, on the other hand, Ottonello and Winberry (2020) find the opposite result that firms with low default risk or low debt burdens are the most responsive to monetary policy shocks because they face a flatter marginal cost of investment finance.
} 
that changes in bank credit to firms are positively associated with economic growth, while changes in bank credit to households are not.

Overall, it seems that the literature using firm level-data tends to find a negative association between debt and investment growth (Lang et al. 1996, Hennessy 2004, Hennessy et al. 2007, Giroud and Mueller 2017, Buera and Karmakar 2019, Kalemli-Ozcan et al. 2019, Blickle and Santos 2020), while studies employing aggregate macro data do not (King and Levine 1993, Rancière et al. 2008, Beck et al. 2012, Mian et al. 2017, Jordà et al. 2020). My conjecture is that aggregate data may not be very informative when there is substantial heterogeneity across firms' balance sheets.

I illustrate further the point that aggregate data may yield different results when the considerable heterogeneity in corporate balance sheets across firms is not taken into account. I run regressions similar to Equation (1) but using US aggregate data from the Flow of Funds (FoF), and the 12-quarter cumulative change in the debt to GDP ratio for both households and corporates, as in Mian et al. (2017). The dependent variable is the cumulative change in real GDP up to ten years ahead. I run specifications with and without controls; in the latter, I add several economic and financial variables, namely the growth rate of household debt and of NFC debt, the fed funds rate, the EBP, a time trend, and a recession dummy. Both specifications, with and without controls, are in line with Mian et al. (2017) and Jordà et al. (2020): only debt build-ups in the household sector are associated with future economic slowdowns (Figure D.2 in the Online Appendix). The results remain robust to excluding the GFC (Figure D.3 in the Online Appendix). All in all, this exercise shows that using aggregate country data may mask important relationships between corporate debt booms and the real economy, as the micro effects can only be uncovered when using more more granular data.

\subsection{Non-linearities: credit and liquidity constraints}

I explore non-linearities in the data by investigating which firm characteristics may contribute to the association between rapid increases in leverage and weaker future investment. My conjecture is that the debt overhang effect may be stronger for firms that are more financially constrained. But it well may be the case that debt build-ups are fundamentally detrimental to the economy, irrespective of the health of the balance sheet of a firm.

The main challenge is in identifying firms in the data that are more financially vulnerable or credit constrained. While leverage seems to be a popular proxy, the literature is still de- 
bating which observables better identify credit-constrained firms (Farre-Mensa and Ljungqvist 2016, Melcangi 2019). The most common measures used in the literature to capture financial constraints include regression-based indices that focus: on the reliance of a firm on external financing (Kaplan and Zingales 1997); on firms with low cash flows, high leverage, weak growth, among others (Whited and Wu 2006); and on younger and smaller firms (Hadlock and Pierce 2010, Fort et al. 2013). But these reduced-form regressions estimated on small samples suffer from out-of-sample extrapolation issues, as the estimated coefficients are applied to a different sample of firms, while assuming parameter stability across firms and time (Hoberg and Maksimovic 2015, Farre-Mensa and Ljungqvist 2016). Farre-Mensa and Ljungqvist (2016) find that the majority of 'constrained' firms identified through these three indices do not behave as if they were constrained; constrained firms are actually able to raise additional debt following an exogenous debt increase (a tax increase), and can use the proceeds of equity issues to increase payouts to shareholders. The authors suggest that constraints identified in the literature may just reflect differences in the growth and financing policies of firms at different stages of their life cycles.

Other measures of financial constraints include firm size (Gertler and Gilchrist 1994, Bernanke et al. 1999), firms that do not pay dividends (Fazzari et al. 1988), the age of the firm (Gertler 1988, Bahaj et al. 2019, Durante et al. 2020), and young firms that do not pay dividends (Cloyne et al. 2019). One of the caveats is that liquid assets do not play a direct role in determining how financially constrained a firm is. The exception includes Jeenas (2019) and Joseph et al. (2019) who argue for using liquid asset holdings, or cash, rather than just leverage alone, to proxy for credit constraints. Moreover, Hoberg and Maksimovic (2015)'s index of financial constraints identifies firms with liquidity issues based on the textual analysis of the Management's Discussion and Analysis (MD\&A) section in firms' 10-Ks.

Against this background, I explore the heterogeneous responses of investment following debt booms with three simple - regression-free - proxies of credit constraints: leverage, liquid assets, and the combination of both. ${ }^{11} \mathrm{I}$ investigate, in particular, whether the relationship between past debt booms and investment growth is monotonic in these three measures. I start by splitting the sample into the same bins of firms as used in Section 3, and adapt Equation (1)

\footnotetext{
${ }^{11}$ In Section 5.5 I also consider Hoberg and Maksimovic (2015)'s index, firm age, and firm size.
} 
to allow for heterogeneous coefficients across groups:

$$
\Delta_{h} \log \left(I_{i, t+h}\right)=\sum_{k=1}^{N}\left[\beta_{k}^{h} \Delta_{12} \text { Debt }_{i, t-1}+\sum_{j=1}^{4} \lambda_{j, k}^{h} X_{i, t-j}\right]+\eta_{i}^{h}+\zeta_{t}^{h}+\epsilon_{i, t+h}
$$

The parameters of interest are $\beta_{k}^{h}=\{1,2,3\}$ which show the relationship between investment spending and debt build-ups for each $k$ bins (low, moderate, and high) of leverage, liquid asset holdings, and debt to liquid assets.

The left panel of Figure D.4 in the Online Appendix shows that it is not clear that high-debt firms are associated with lower investment in a statistically significant way after a debt boom. In addition, the decline in investment appears to be non-monotonic in leverage: firms with moderate debt levels (second tertile of the distribution) tend to be associated with larger declines in investment than high-debt firms: the right panel depicts the difference in the estimates between high-debt firms and the other debt groups. There is also no evidence that high-debt firms experience different investment dynamics compared to low-debt firms. At face value, it seems that leverage may not be capturing credit constraints adequately (Jeenas 2019).

When I break the sample into bins of liquid asset holdings, I get more precise estimates for firms with low liquid asset holdings: debt build-ups are associated with statistically significant lower future investment (left panel of Figure D.5 in the Online Appendix). The coefficients are statistically different from firms with high liquid assets, but not from firms with moderate levels of liquid assets (right panel). This non-monotonicity in liquidity levels suggest that liquid assets may be only capturing financial constraints partially.

Just taking one of the dimensions of a firm balance sheet at a time - leverage or liquid assets - may provide us with an incomplete picture of how financially vulnerable and credit constrained a firm is. For example, high debt may simply reflect access to credit markets, so we cannot make a direct link to credit constraints. It can also be related to good investment opportunities, in which higher debt is anticipating future investment growth (Lang et al. 1996, Barbiero et al. 2020) In addition, highly indebted firms may have considerable liquid assets that make debt not that relevant as a proxy for financial constraints (Fahlenbrach et al. 2020). A similar ambiguity may exist for liquidity asset holdings. Firms may choose higher liquidity because they may be credit constrained or for precautionary reasons, so as to provide them with a cushion against unfavourable credit supply shocks (Almeida et al. 2004, Bates et al. 2009, Campello et al. 2010, Bacchetta et al. 2019, Joseph et al. 2019, Melcangi 2019, Cunha and 
Pollet 2020). Management of debt and liquid assets should thus be seen as distinct processes given the different hedging and liquidity properties of cash and debt (Jeenas 2019).

I now combine leverage with liquid assets to proxy for financial constraints and check the investment response following a debt boom. Specifically, I divide leverage by liquid asset holdings, and split the sample into three bins of the debt-to-liquid asset ratio. I find that firms with a high debt relative to their liquid assets are associated with a larger decline in investment spending following debt build-ups (Figure D.6 in the Online Appendix). This difference is statistically significant vis-à-vis firms with a low ratio, and for longer horizons relative to firms with a moderate ratio. Overall, combining leverage and liquid assets seems to contain more information to uncover the heterogeneity in the dynamics of investment following prolonged periods of debt accumulation than just using leverage or liquidity separately.

A high debt-to-liquid asset ratio results from either high debt for a given level of liquid assets, or from low liquid assets for a given level of debt. Ideally, I would like to study the behaviour of those firms that are most likely both credit and liquidity constrained. In this spirit, the rest of the paper will go a step further and proxy for financial constraints based on firms with high levels of debt and with limited liquid assets. My assumption is that firms that are both highly indebted and hold limited liquid assets may find it more difficult to avoid cutting investment in the medium term following debt booms; because they cannot raise additional funding, or not as much as they would like to, and because they cannot tap into their liquid assets.

I look at firms that belong simultaneously to the top tertile of the leverage ratio distribution, and to the bottom tertile of the liquidity ratio distribution. ${ }^{12}$ I will call these firms 'Vulnerable'; they account for around $14 \%$ of the sample. This definition is similar to Fahlenbrach et al. (2020)'s, who define firms as having low financial flexibility if they belong to both the bottom quartile of the cash over assets distribution and to the top quartile of the long-term debt over assets distribution. They find that stock returns of firms with less financial flexibility performed substantially worse than firms with greater financial flexibility during the GFC in 2008 and the COVID-19 shock in 2020. They explain their results with the difficulty that firms with less financial flexibility face in funding their cash flow shortfall, so that the implication is that they descend more rapidly into financial distress. Along similar lines, Ding et al. (2021) find that the fall in stock prices during the early months of the COVID-19 shock was milder for firms with stronger balance sheets, as reflected in greater cash ratios and lower leverage, greater unused

\footnotetext{
${ }^{12} \mathrm{My}$ main results are not sensitive to selecting different cuts of the data, such as the top quartile/quintile of leverage and the bottom quartile/quintile of liquid assets.
} 
lines of credit, and larger profits.

Table 2 shows that the typical vulnerable firm is characterised by weak fundamentals, such as negative net liquidity asset holdings, and may face high corporate financing costs as indicated by a lower ICR than the rest of the other firms (Palomino et al. 2019). Recall that, by construction, these firms also have high leverage which, combined with the other characteristics, could make it challenging for firms to mitigate the effects of a negative shock. In addition, these firms tend to be large and experience lower investment growth than the rest of the firms in the sample. Furthermore, the typical vulnerable firm has experienced substantial swings in debt build-ups over the last decades: firms accumulate substantial debt in the run-up to recessions, but then delever sharply as the economy enters a recession (Figure 7). By contrast, the typical non-vulnerable firm goes through much smoother credit cycles.

Table 2: Descriptive statistics for vulnerable firms vs other firms (median values)

\begin{tabular}{lccccc}
\hline \hline & Size & Leverage & Liquidity & $\Delta \log ($ capex $)$ & ICR \\
\hline Vulnerable firms & 1508.10 & 0.37 & -0.01 & 3.58 & 2.85 \\
Other firms & 212.31 & 0.19 & 0.24 & 6.83 & 4.54 \\
\hline \hline
\end{tabular}

Notes: Size refers to total real assets in 2009 USD, leverage to the ratio of short-term and long-term debt to total assets, liquidity to the ratio of net current assets to total assets, capex to capital spending, and ICR to the ratio of EBIT to interest expenses.

Figure 7: Corporate debt build-ups for vulnerable firms vs non-vulnerable firms

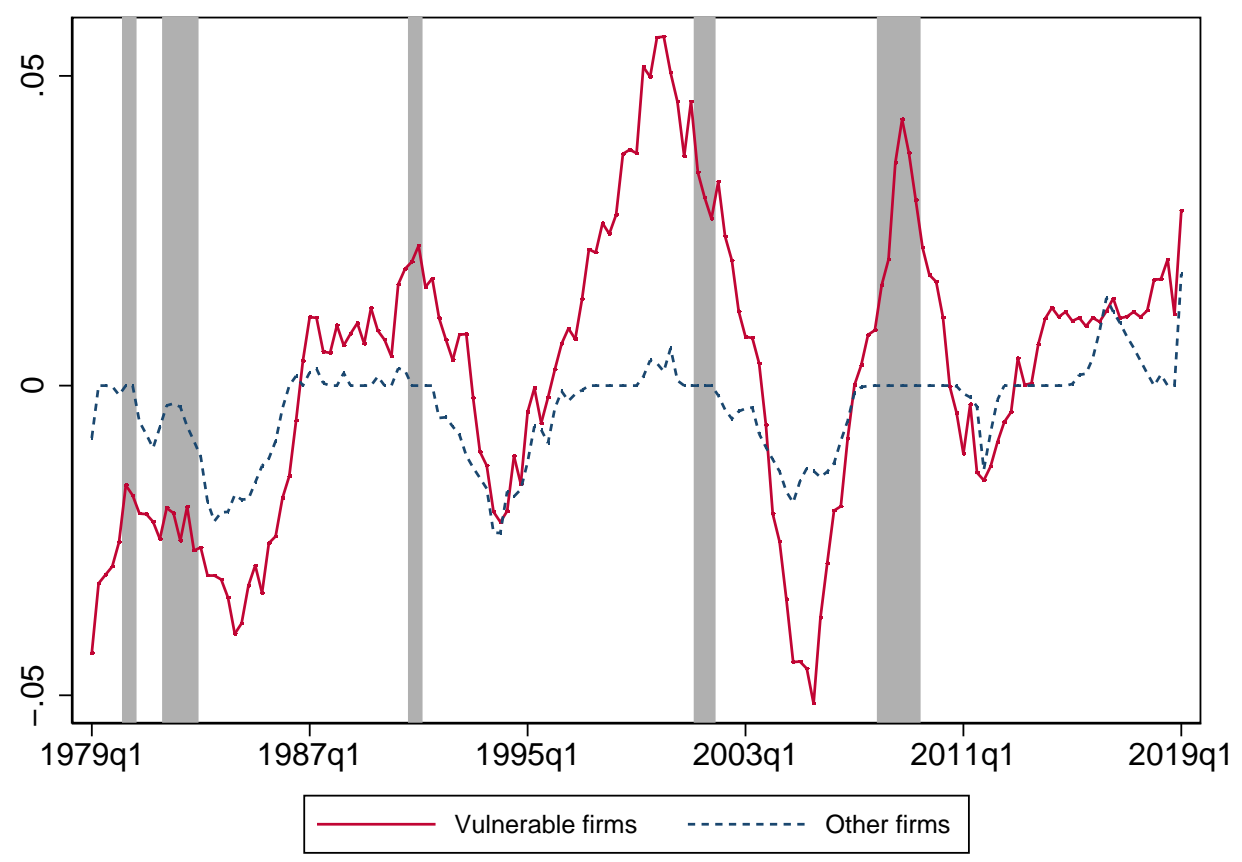

Sources: Compustat, and author's calculations.

Notes: Vulnerable firms refer to firms that, at each point in time, belong simultaneously to the top tertile of the leverage ratio and to the first tertile of the liquid asset ratio. The shaded area indicates recessions as defined by the NBER.

I adjust Equation (2) so that the beta coefficients refer to the elasticity of investment spend- 
ing to debt build-ups for vulnerable and other firms: $\beta_{k}^{h}=\{$ Vulnerable, Other $\}$. Note that the concept of vulnerability for a specific firm is allowed to change over time: the estimated coefficients in the LP framework measure the average effect of debt build-ups on investment growth, as a function of state-dependent financial constraints. If the average effect of debt build-ups is likely to affect the state-dependencies in the forecasting horizon, for instance by making a non-vulnerable firm become vulnerable, this will be reflected in the estimated coefficient. The other transitions between states (vulnerable or non-vulnerable) that are independent of the debt build-up will be captured by the state-dependent control variables. ${ }^{13}$

The impulse responses in Figure 8 show that sustained increases in leverage for highly indebted firms and with low liquid assets are associated with substantially lower investment spending over the medium term. At the peak impact, reached after four years, a 10 p.p. increase in debt build-ups is associated with lower investment of $4.6 \%$. The contraction in investment for the other firms in the sample (the non-vulnerable) is less obvious to discern; the estimates include the zero for most short- to medium-term horizons, and only become statistically significant after four years. The magnitude of the decline is also much smaller compared to vulnerable firms. For every 10 p.p. increase in the pace of credit accumulation, vulnerable firms reduce their investment spending growth by roughly 2.5 p.p. more than other firms after five years. This difference is statistically significant at the $90 \%$ confidence level (right panel). This result highlights the role that financial constraints may have in amplifying the negative effects of a debt boom on investment.

In Figure D.7 in the Online Appendix I document that debt build-ups in vulnerable firms are associated with a larger and statistically significant increase in corporate yields relative to non-vulnerable firms (up to four years ahead). This is again suggestive of financial constraints amplifying the negative effect of debt booms through higher borrowing costs, in line with highly leveraged firms experiencing higher credit spreads around the GFC (Blickle and Santos 2020, Ebsim et al. 2020). ${ }^{14}$ Overall, my results can be placed in the context of models with financial constraints that predict that borrowing constraints prevent firms to finance investment spending when the rise in debt becomes unsustainable. ${ }^{15}$

\footnotetext{
${ }^{13}$ The LP method offers advantages in this regard relative to Markov-switching or threshold VAR models. In these models the impulse responses assume that there is no change in the state-dependencies, potentially biasing the coefficients.

${ }^{14}$ The increase in bond yields for vulnerable firms may be a lower bound, as suggested by Blickle and Santos (2020), given that some vulnerable firms may not have been able to issue new debt during a debt overhang.

${ }^{15}$ The results in the paper point consistently to a debt overhang effect on investment. But one may wonder whether the decline in investment after a debt boom may just be capturing an investment spending normalisation: firms may accumulate considerable debt in order to finance major investments, after which investment would
} 
Figure 8: Impulse responses of investment spending: vulnerable firms

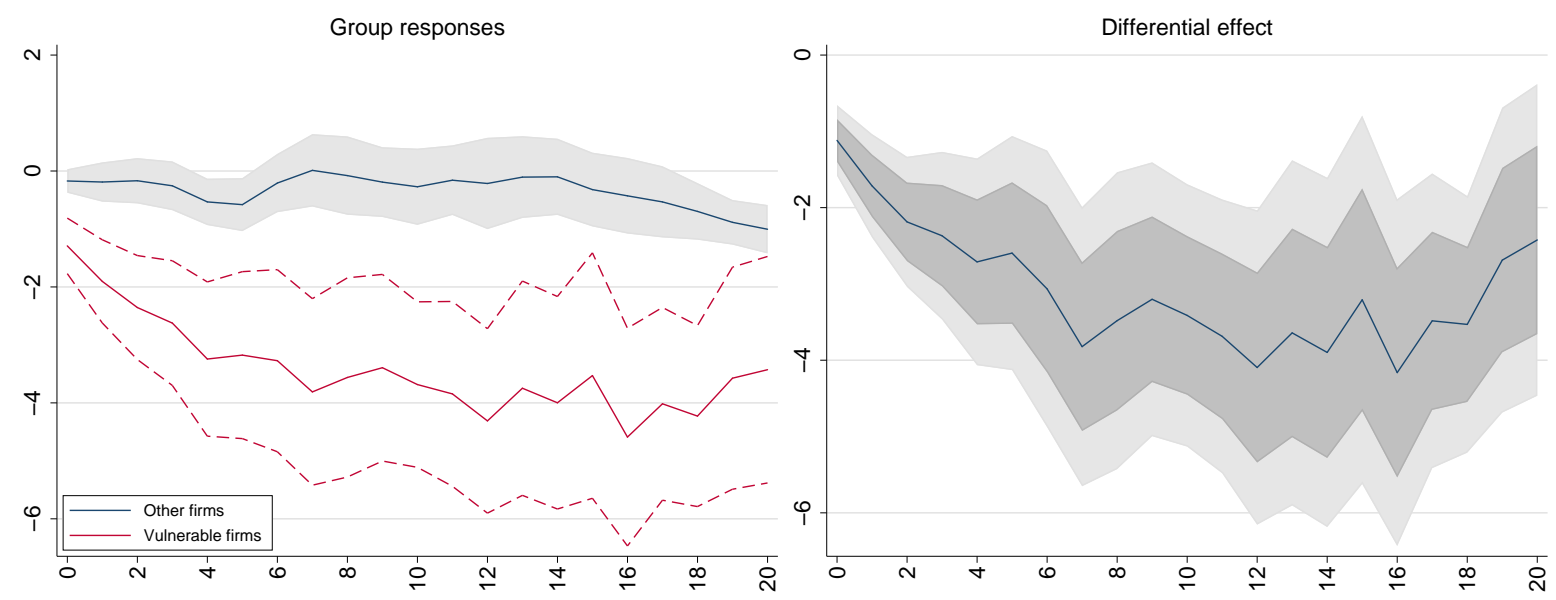

Notes: Cumulative impulse responses of capex to a 10 p.p. increase in corporate debt build-ups up to 20 quarters ahead. The red lines refer to the response of vulnerable firms and associated $90 \%$ confidence bands. The blue line and grey area refer to the response and $90 \%$ confidence bands for other firms. The right panel depicts the difference, and associated $68 \%$ and $90 \%$ confidence bands, between the responses of vulnerable firms and all other firms.

\subsection{Resilient firms}

I check the robustness of my results by breaking down the 'Other firms' component. This group is rather large in my dataset, and heterogeneous across several balance sheet characteristics. Within these firms, I select those with low debt to assets (bottom tertile) and high liquid asset holdings (top tertile), which account for around $19 \%$ of the sample. In Table D.1 in the Online Appendix I show that these 'Resilient' firms tend to be smaller, invest the most in their capital stock, and exhibit the highest ICR relative to all the other firms in the sample. In addition, Figure D.8 in the Online Appendix shows that the typical resilient firm goes through much smoother credit cycles.

In theory, a firm with low debt relative to their assets and high liquid asset holdings may reflect deliberate management decisions to keep the firm healthy and with strong balance sheets. In this case I would expect debt accumulation to lead to higher investment spending, in line with the literature that establishes a positive relationship between finance and growth (King and Levine 1993, Levine 2005, Rancière et al. 2008, Beck et al. 2012). But it is also perfectly

return to a more normal level. I believe my results and empirical setting rule out that hypothesis. First, the main regression includes four lags of the dependent variable, which should control for reversion to the mean effects. Second, I find that investment of vulnerable firms in the aftermath of a build-up in debt does not recover over a five-year period (Figure 8). Assuming that the spending normalisation channel dominated, we would not expect the fall in investment to persist for such a long period. In addition, the difference in the investment profile between vulnerable firms and all other firms in the dataset remains statistically significant for the whole horizon. Third, the spending normalisation channel would in principle not involve an increase in borrowing costs, as investors would perceive the decline in investment as an adjustment to a more normal level of investment. The increase in borrowing costs that I find for vulnerable firms in Figure D.7 in the Online Appendix suggests that a corporate debt boom is followed by a tightening in credit supply for these firms: there is less credit available, or/and at a higher price. This is again suggestive of a debt overhang effect. 
possible that firms with low debt and high liquidity may face some form of credit constraints, given the possible endogeneity in the choice of how much liquid assets to hold (Bates et al. 2009, Melcangi 2019, Bacchetta et al. 2019). If this is true, any prolonged debt build-up would inevitably lead to lower investment spending over the medium term. I let the data speak and check which theory fits best the empirical findings.

I draw three main findings from Figure 9. First, the response of vulnerable firms remains robust to estimating the model with one additional group of firms. Second, debt build-ups for the 'other' firms in the sample are also associated with declines in investment, but to a much smaller extent. Third, firms with low debt and high liquid asset holdings experience increases in investment in the aftermath of debt build-ups, in line with models that predict a positive link between leverage and investment, as long as a crisis does not occur (Rancière et al. 2008). This suggests that we are in the presence of firms whose debt accumulation process does not harm investment; actually the opposite. These firms resemble Fahlenbrach et al. (2020)'s firms with high financial flexibility, which can easily fund a cash flow shortfall and, therefore, are less affected by negative shocks. I find a large and statistically significant difference in the investment behaviour between vulnerable and resilient firms: for every 10 p.p. increase in debt build-ups, vulnerable firms experience weaker investment spending growth of roughly 5 p.p. after five years.

Figure 9: Impulse responses of investment spending: adding resilient firms
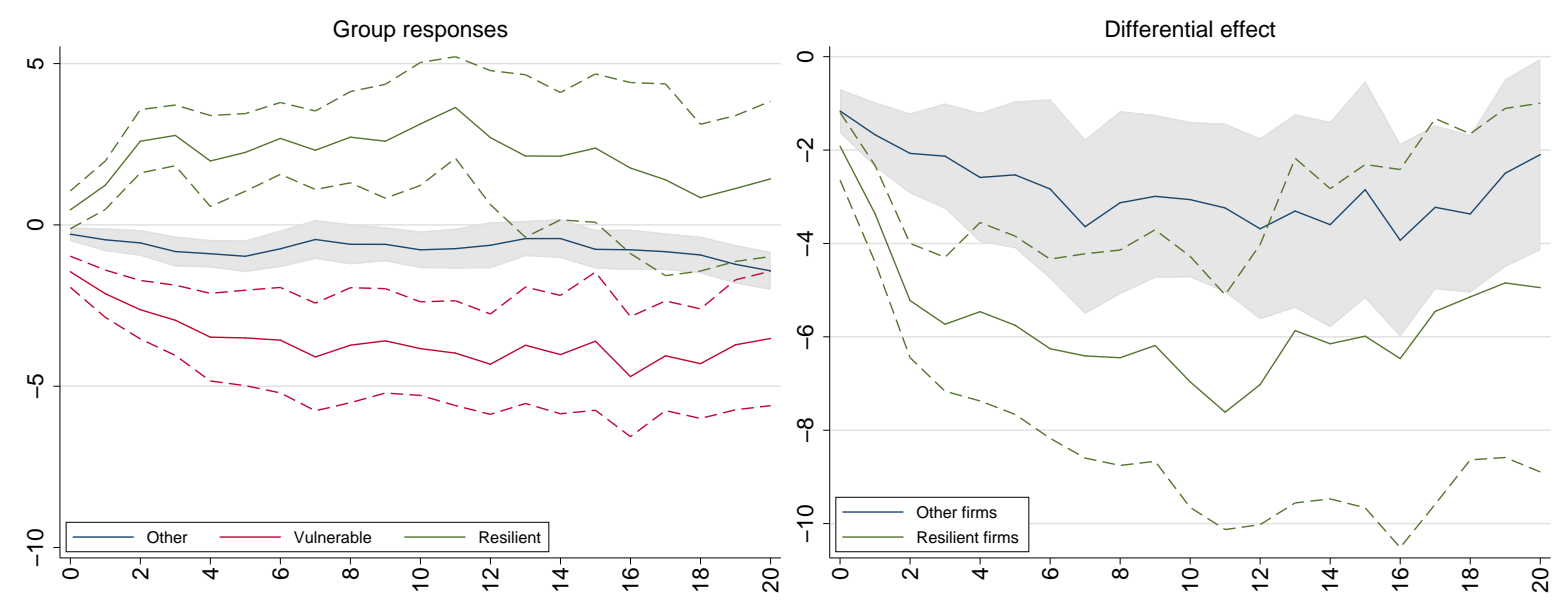

Notes: Cumulative impulse responses of capex to a 10 p.p. increase in corporate debt build-ups up to 20 quarters ahead. The red (green) lines refer to the response of vulnerable (resilient) firms and associated $90 \%$ confidence bands. The blue line and grey area refer to the response and $90 \%$ confidence bands for other firms. The right panel depicts the difference, and associated $90 \%$ confidence bands, between the responses of vulnerable firms and resilient firms (green lines), and between vulnerable and all other firms (blue line and grey area).

In the Online Appendix (Figures C.1 and C.2) I find some supporting evidence showing that constrained firms tend to burn through their liquid assets in the aftermath of debt booms 
(Campello et al. 2010). The decline in liquid assets may reflect the need to tap into liquidity to mitigate the impact of binding credit constraints. In contrast, I find that resilient firms tend to strengthen their liquid asset position following debt booms - presumably for precautionary reasons and to prevent them from becoming constrained (Melcangi 2019).

I have shown that high debt and low liquid asset holdings constitute key ingredients for signalling financial risks and weaker investment in the aftermath of a debt boom. The central takeaway in this paper supports the view that persistent debt booms ultimately become unsustainable, leading firms who are financially constrained, and that may face higher (re-)financing costs and tighter credit conditions, to cut back on investment (Campello et al. 2010, Hoberg and Maksimovic 2015, Giroud and Mueller 2017, Buera and Karmakar 2019, Kalemli-Ozcan et al. 2019, Barbiero et al. 2020, Blickle and Santos 2020). Debt booms or debt misalignments in the corporate sector may thus sow the seeds of damaging and costly financial crises in the spirit of Kindleberger (1978).

\subsection{Debt structure and rollover risk}

The literature has found that firms that rely mostly on bank debt to finance investment projects may be more exposed to credit supply shocks, given their limited ability to substitute bank debt with external market financing (Kashyap et al. 1993, Becker and Ivashina 2014). ${ }^{16}$ My aim here is to ask a related question but from a different angle: do firms with debt booms originating from traditional bank loans experience larger investment contractions than firms that have debt booms in market debt? My hypothesis is that banks may be unwilling to extend credit to firms that are accumulating too much bank loans, even after controlling for the share of bank loans in total debt. Lenders may realise that firms with booms in bank loans may be more exposed to credit supply shocks, and thus may be at a higher risk of default.

I match Compustat data with information on the firms' debt structure from Capital IQ. The sample covers only around $46 \%$ of the baseline sample due to missing information for some of the firms, especially before 2001. I therefore start the analysis from 2001 onwards. I break down debt build-ups into market-based and bank-based in Equation (2). I also control for the share of bank debt in total debt. The left panel in Figure 10 shows the difference in the response of

\footnotetext{
${ }^{16}$ The literature on the transmission of monetary policy shocks has found that firms with a higher share of bank debt in total debt tend to be more responsive to monetary policy. This result is rationalised in a context where a large portion of bank debt carries a floating rate, while most market debt is issued at a fixed rate (Ippolito et al. 2018). But Darmouni et al. (2020) find the opposite result; firms with a larger share of bond financing may face greater frictions in bond markets and have more difficulty to refinance debt.
} 
bank debt build-ups and market debt build-ups for vulnerable and non-vulnerable firms. I find that build-ups in bank loans for vulnerable firms appear to be associated with larger slowdowns in investment than build-ups originated in market debt (up to four years ahead). In contrast, I do not find any statistical support for a differential effect between bank debt and market debt build-ups for non-vulnerable firms, suggesting that investment growth for these unconstrained firms evolves the same way irrespective of the source of the debt boom. The right panel indicates that the fall in investment associated with booms in bank loans seems to be statistically larger for vulnerable firms than for the other firms up to three years ahead. Overall, I believe this is a novel result in the literature: the source of the debt build-up, after controlling for the share of bank debt in total debt, is indicative of larger investment cuts in the aftermath of a debt boom only for vulnerable firms.

Figure 10: Differences in responses between bank debt and market debt build-ups

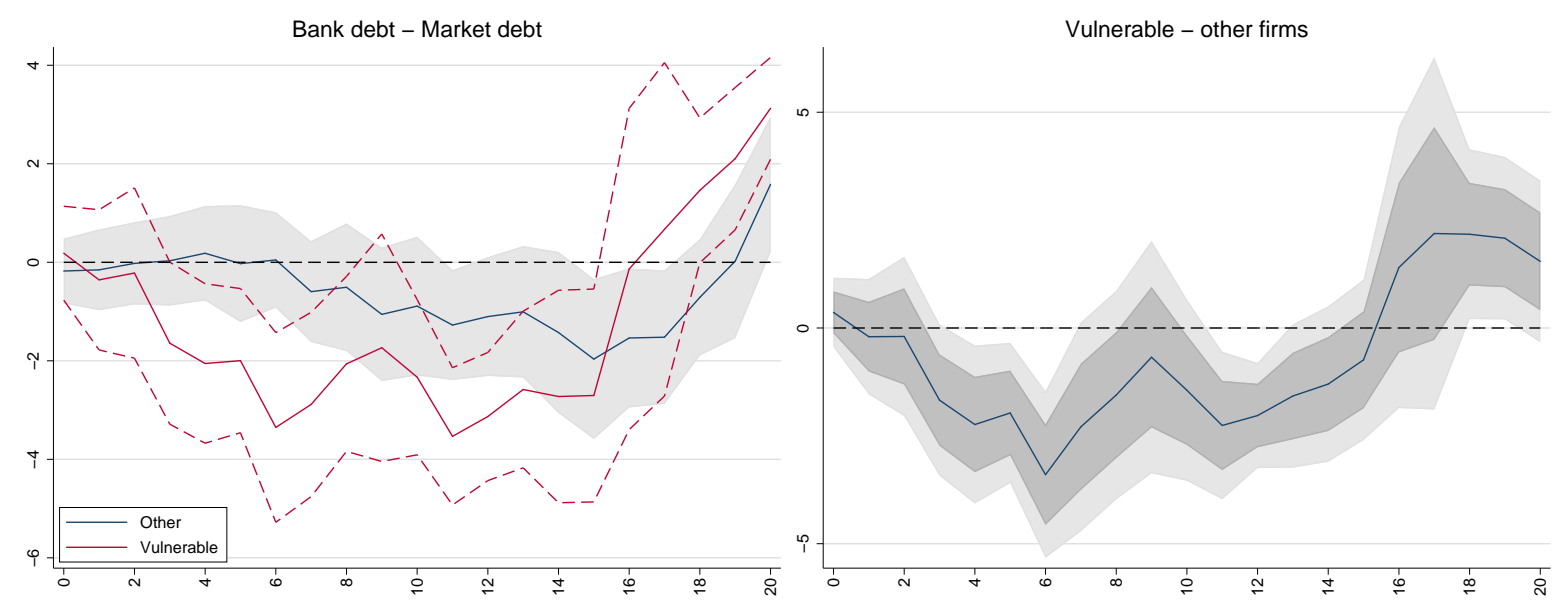

Notes: Cumulative impulse responses of capex to a 10 p.p. increase in the difference between bank debt build-ups and market debt build-ups up to 20 quarters ahead. The right panel shows the difference between vulnerable and other firms. The dark (light) grey area refers to the $68 \%$ and $90 \%$ confidence bands.

I now focus on understanding how the debt maturity structure matters to uncover the association between debt booms and investment. The literature has found that the debt overhang effect might be amplified for firms that rely more on short-term debt financing and are therefore more subject to rollover risk (Acharya et al. 2011, Buera and Karmakar 2019, Kalemli-Ozcan et al. 2019, Barbiero et al. 2020, Fahlenbrach et al. 2020). Such risks appear to be particularly elevated around crisis periods, when the value of the collateral falls (Acharya et al. 2011). Kalemli-Ozcan et al. (2019), for instance, provide evidence that EU firms with a shorter maturity of debt reduced investment more in the aftermath of the GFC. Along the same lines, Barbiero et al. (2020) find that firms with a larger share of short-term debt invest relatively less if they are facing good growth opportunities. In addition, using the 2010 Portuguese sovereign debt crisis as an example of a large financial shock, Buera and Karmakar (2019) show that 
highly leveraged firms and firms that had a larger share of short-term debt on their balance sheets recorded a stronger contraction in credit, investment and employment.

Against this background, I ask a related question: do firms with booms in short-term debt experience larger investment contractions than firms that have debt booms in long-term debt? My assumption is that investors may not be willing to extend credit to firms that run considerable booms in short-term debt, even after controlling for the share of short-term debt in total debt. I would expect this effect to be stronger for vulnerable firms, as they may be more exposed to repricing risks from investors or banks.

I break debt build-ups into short- and long-term debt in Equation (2), and also control for the share of short-term debt in total debt. Against my initial prior, I do not find any statistical support for a boom in short-term debt having a stronger impact than a debt boom in long-term debt for vulnerable firms (left panel of Figure 11). Unconstrained firms that have credit booms in short-term debt tend to actually experience smaller declines in investment than firms with credit booms in long-term debt. While long-term debt may insulate firms from a potential fall in credit spreads, short-term debt is usually cheaper. The mixed results I find may thus reflect a small trade-off between short- and long-term debt that a firm with a healthy balance sheet may be willing to pay. But we should take some caution in drawing strong conclusions from these results; the difference between vulnerable and other firms in the investment response to a credit boom in short-term debt relative to a credit boom in long-term debt is not significant at conventional levels of significance (right panel). Overall, my results suggest that the maturity of debt does not seem to play a role in determining the investment path in the aftermath of a debt boom.

\subsection{Alternative measures of financial constraints}

I have argued that combining the right tail of the firms' leverage distribution with the left tail of their liquid asset distribution provides a reasonable indication of financial constraints. In this section I use three alternative measures of financial constraints to check the sensitivity of my results: (i) Hoberg and Maksimovic (2015)'s (HM) index of financial constraints based on firms' 10-Ks reports, (ii) the age of the firm (Gertler 1988, Bahaj et al. 2019, Cloyne et al. 2019, Durante et al. 2020), and (iii) and the firm size (Gertler and Gilchrist 1994, Bernanke et al. 1999).

First, I match my data with the HM index; I am able to match 4,210 unique firms, resulting 
Figure 11: Differences in responses between short-term debt and long-term debt build-ups

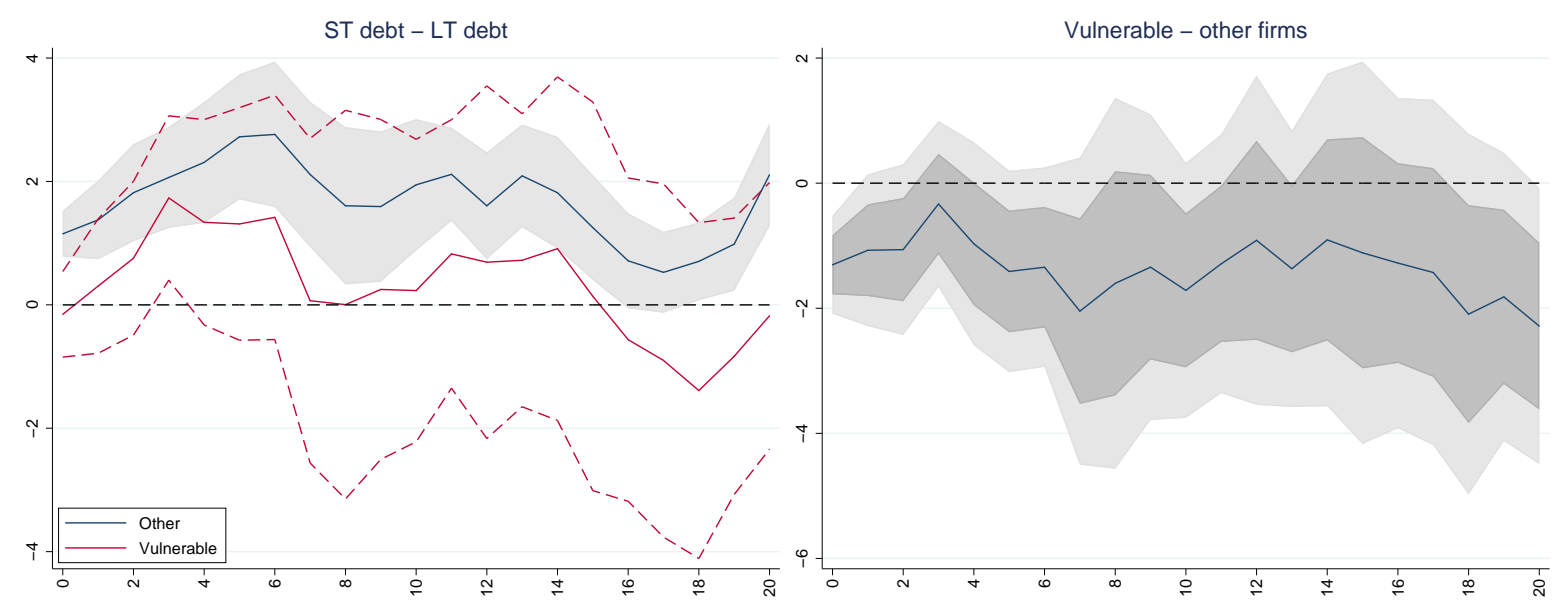

Notes: Cumulative impulse responses of capex to a 10 p.p. increase in the difference between short-term debt build-ups and long-term debt build-ups up to 20 quarters ahead. The right panel shows the difference between vulnerable and other firms. The dark (light) grey area refers to the $68 \%$ and $90 \%$ confidence bands.

in 119,583 firm-quarter observations. The HM index identifies firms with liquidity issues based on the textual analysis of the Management's Discussion and Analysis (MD\&A) section in firms' 10-Ks. Specifically, I use the index delaycon, where higher values represent firms that are at risk of delaying their investments due to issues with liquidity. Hoberg and Maksimovic (2015)'s find that firms that are more financially constrained cut investment more following negative shocks. Their measure also performs better in predicting underinvestment than the traditional measures of financial constraints, such as those from Kaplan and Zingales (1997), and Whited and $\mathrm{Wu}$ (2006). Using the same HM index, Fahlenbrach et al. (2020) find that firms that are financially constrained had lower stock returns during the worse period of the COVID-19 shock.

One of the limitations of the HM index is the frequency and time span: annual data over 1997-2015. In addition, it is highly autocorrelated, around 0.5, a bit higher than my definition of vulnerable firms (a one-year autocorrelation of 0.37). I run a modified version of Equation (1) by interacting the debt build-up variable with the HM index. I then define constrained firms as those belonging to the $90^{\text {th }}$ percentile, and unconstrained as those in the $10^{\text {th }}$ percentile. Figure D.9 in the Online Appendix shows that the investment of firms in the $90^{\text {th }}$ percentile experienced statistically significant weaker investment after debt build-ups, in line with my main results.

Second, I use the age of the firm as an alternative proxy for financial constraints. Recent literature has argued that young firms tend to be more responsive to monetary policy shocks, as they typically face more difficulties in securing credit, and are therefore more prone to being financially constrained (Bahaj et al. 2019, Cloyne et al. 2019, Durante et al. 2020). But Hoberg 
and Maksimovic (2015) cautions that a large fraction of constrained firms cannot be identified just by using age, or/and firm size.

The age variable is sparsely populated in Compustat, so I match my data with Jay Ritter's database on founding dates of firms since 1975. I am able to match 997 unique firms, resulting in 45,555 firm-quarter observations. I define young firms as those less or equal than ten years old, and old firms as those older than ten years. Figure D.10 in the Online Appendix shows that a debt build-up in young firms is associated with weaker investment compared to old firms. The picture is relatively unchanged when I use 15 years in Figure D.11 in the Online Appendix as the threshold (Bahaj et al. 2019, Cloyne et al. 2019). The main difference when using age as a measure of financial constraints relative to my baseline results is larger standard errors. This implies a lower degree of confidence in establishing a statistically significant difference in the investment response between constrained and unconstrained firms.

My third proxy of financial constraints considers the size of the firm, measured with total real assets in 2009 USD. An early literature dating back to Gertler and Gilchrist (1994) shows that small firms are more financially constrained, making them more responsive to monetary policy shocks.

Using the bottom tertile of the firm size distribution to capture financially constrained firms, I do not find any statistical significant association between investment and debt build-ups for small firms (Figure D.12 in the Online Appendix). My results seem to actually point in the opposite direction. In addition, large firms tend to experience statistically significant weaker investment compared to small firms (right panel of Figure D.12 in the Online Appendix). This goes against the notion that small firms may be more financially constrained. My apparent counter-intuitive result may be related to the fact that a typical large firm has high levels of debt, small liquidity buffers, and weaker balance sheets as measured by low ICRs. Moreover, Crouzet and Mehrotra (2020) argue that firm size may not be a good proxy for financial constraints because of the lack of co-movement between investment and debt over the cycle for small firms after a monetary policy shock. Farre-Mensa and Ljungqvist (2016) also argue that small (and younger) firms do not behave differently from unconstrained firms (a similar point made by Hoberg and Maksimovic 2015). 


\subsection{Intangible investment}

The central argument in the paper is that debt booms can weigh negatively on aggregate demand via weaker capital expenditures (capex), which refer to funds used by a firm to acquire, upgrade, and maintain its physical assets (property, plants, buildings, technology, and equipment). This type of tangible investment is relatively straightforward to measure, and it is reported on firms' balance sheets.

In this section I explore other indirect effects of debt booms, particularly the impact on long-run productivity growth measured with intangible investments. In fact, recent literature has documented a steady increase in the importance of intangible assets related to knowledge and organisational capacity: firms' investment in their employees, brand, and knowledge capital. Available estimates range from one third (Corrado et al. 2009) to one half of firms' total capital stock (Ewens et al. 2019, Eisfeldt et al. 2020, Belo et al. 2021). The issue is that most intangible assets are not reported on corporate balance sheets. This is particularly true for internally created intangibles; a firm's internal Research and Development (R\&D) costs and Selling, General, and Administrative (SG\&A) activities are recorded as expenses and therefore do not appear on its balance sheet (Ewens et al. 2019).

I use the estimates of intangible assets from Eisfeldt et al. (2020), who apply the perpetual inventory method to flows of SG\&A expenses, under given assumptions about depreciation and initial values. Eisfeldt et al. (2020) show that a value portfolio that adds their measure of intangible capital to book assets outperforms standard value portfolio measures. As a result, Eisfeldt et al. (2020) argue that the 'investment puzzle' over the last years - the disconnect between firm valuation and investment - can be solved when accounting for intangible investment. Their measure of intangible assets is available on an annual frequency spanning 1975 to 2018.

I redo the analysis above by replacing capex with intangible capital as a ratio of total assets in Equation (2). Figure 12 shows that debt booms in financially vulnerable firms are associated not only with weaker future capex growth, but also with weaker intangible capital growth. This result is, again, suggestive of a powerful negative debt overhang effect which prevents financially constrained firms from financing their investment, both in fixed assets and intangible assets. On the other hand, debt build-ups in unconstrained firms seem to be associated with higher intangible capital up to 12 quarters ahead. These results, together with Figure 8, suggest that debt booms seem to be detrimental only for credit-and liquidity-constrained firms. 
Figure 12: Impulse responses of intangible investment

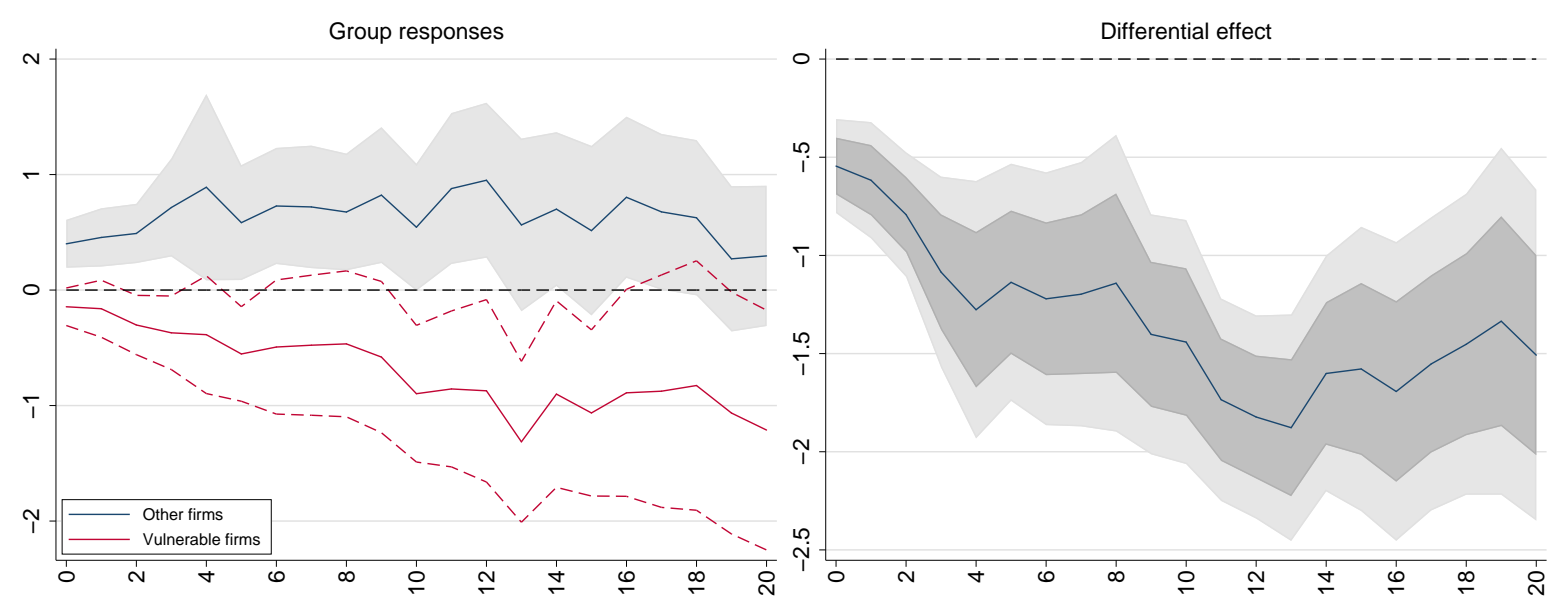

Notes: Cumulative impulse responses of the intangible capital-to-asset ratio from Eisfeldt et al. (2020) to a 10 p.p. increase in corporate debt build-ups up to 20 quarters ahead. The red lines refer to the response of vulnerable firms and associated 90\% confidence bands. The blue line and grey area refer to the response and $90 \%$ confidence bands for other firms. The right panel depicts the difference, and associated $68 \%$ and $90 \%$ confidence bands, between the responses of vulnerable firms and all other firms.

As a robustness check, I use the implied intangible stocks from Ewens et al. (2019). This paper develops a model that incorporates market prices of intangible assets to estimate capitalisation parameters from a firm's prior flows of intangible investments. The data are available also on an annual basis, but stops one year earlier (until 2017). It is not surprising that I get a similar picture when using intangible capital from Ewens et al. (2019) since their estimated measure is highly correlated (0.89) with the estimates of intangible assets from Eisfeldt et al. (2020): vulnerable firms cut intangible investment in the aftermath of debt booms, while unconstrained firms experience an increase (Figure D.13 in the Online Appendix). But the point estimates are, however, surrounded by considerably larger standard errors.

\section{Tail risk}

The central argument in the paper is that corporate debt booms are associated with lower future investment growth, particularly for the tail of firms that may be more financially constrained. Another way to look at non-linearities is to investigate whether debt build-ups affect different parts (quantiles) of the future conditional investment distribution in the same way. Using quantile regressions I can, for instance, study the left tail of investment growth, to check whether debt booms in the corporate sector amplify downside risks to investment. This exercise is in the spirit of the so-called 'Growth-at-Risk' approach, which uses quantile regressions to estimate the distribution of GDP growth conditional on economic and financial variables (Adrian et al. 2019, 2021). 
The general form of the estimator beta for each quantile $\tau$ at each horizon $h$ that minimises the quantile weighted absolute value of errors if given by: ${ }^{17}$

$$
\begin{aligned}
\hat{\beta}^{h}(\tau)=\operatorname{argmin}_{\beta^{h}(\tau)} \sum_{t=1}^{T-h}( & \left(\mathbb{1}_{\Delta_{h} I_{i, t+h}>X_{i, t} \beta_{\tau}^{h}}\left|\Delta_{h} I_{i, t+h}-X_{i, t} \beta_{\tau}^{h}\right|\right. \\
& \left.+(1-\tau) . \mathbb{1}_{\Delta_{h} I_{i, t+h}<X_{i, t} \beta_{\tau}}\left|\Delta_{h} I_{i, t+h}-X_{i, t} \beta_{\tau}^{h}\right|\right),
\end{aligned}
$$

where $\mathbb{1}$ denotes the indicator function, $\Delta_{h} I_{i, t+h}$ is investment growth at horizon $h$, and $X_{i, t}$ is a vector of all explanatory variables. Since my framework is a panel quantile regression, I need to deal with fixed effects to avoid estimation bias. The literature has estimated panel quantile regressions mostly by restricting fixed effects to be the same across different quantiles (Canay 2011). One of the few recent exceptions is Adrian et al. (2021), who estimate panel quantile regressions with quantile-specific country fixed effects. They are able to do so because their time series (quarterly data since the mid-70s) is much larger than their N (11 advanced economies). But since my panel has N larger than T, I follow Machado and Santos Silva (2019) who use a quantiles-via-moments estimator that is valid in my context. Specifically, I consider the following location-scale model that allows for quantile-specific fixed effects:

$$
\Delta_{h} I_{i, t+h}=\eta_{i}^{h}+\beta^{h} X_{i, t}+\zeta_{t}^{h}+\left(\delta_{i}^{h}+\gamma^{h} X_{i, t}\right) \epsilon_{i, t+h}
$$

The quantile of $\Delta_{h} I_{i, t+h}$ conditional on $X_{i, t}$, where $\tau$ refers to the quantiles under consideration is given by:

$$
Q\left(\Delta_{h} I_{i, t+h} \mid X_{i, t}\right)=\left(\eta_{i}^{h}+\delta_{i}^{h} q_{\tau}^{h}\right)+X_{i, t}\left(\beta^{h}+\gamma^{h} q_{\tau}^{h}\right)
$$

The quantile- $\tau$ fixed effect for each horizon $h$ is given by:

$$
\hat{\eta}_{i}^{h}(\tau)=\hat{\eta}_{i}^{h}+\hat{\delta}_{i}^{h} q_{\tau}
$$

where $\delta_{i}^{h}$ allows fixed effects to affect the entire distribution of investment growth. The beta $\beta^{h}$ coefficient of interest that measures how debt booms affect the $\tau$ quantile of the conditional distribution of investment growth can then be estimated as follows:

$$
\hat{\beta}^{h}\left(\tau \mid X_{i, t}\right)=\hat{\beta}^{h}+\hat{\gamma}^{h} q_{\tau}^{h},
$$

\footnotetext{
${ }^{17}$ To simplify the exposition, I omit from the notation the logarithm on the left-hand side, the lags on the right-hand side, and consider $X_{i, t}$ as a vector of all explanatory variables, including the debt build-up variable and the lags of the dependent variable.
} 
The $\hat{\beta}$ coefficients track how the conditional distribution of investment growth evolves after debt booms, while in previous regressions I had only looked at the mean response of investment. I find strong statistical evidence that corporate debt booms typically affect more the left tail of the investment growth distribution - Figure 13 plots the $\hat{\beta}$ for each percentile after four quarters (left panel) and 20 quarters (right panel). This indicates that debt booms amplify the decline in investment growth in periods of low investment growth. For example, following a 10 p.p. increase in corporate debt build-ups, investment for the $10^{\text {th }}$ percentile declines by $2 \%$ after five years, which compares with $1.2 \%$ for the median, and $0.7 \%$ for the $80^{\text {th }}$ percentile. ${ }^{18}$ In contrast, there is no statistical support at the $90 \%$ confidence level of significance of weaker investment for the top two percentiles. My results contrast with those from Jordà et al. (2020), who find that corporate debt booms do not increase downside risks to GDP growth, measured with the $20^{\text {th }}$ percentile; they find that only household debt booms affect the economy's tail risk. But my results are aligned with those in Aikman et al. (2019) and Adrian et al. (2021), who find that rapid growth in both household or corporate debt raise downside risks for GDP growth.

Figure 13: Impulse responses of investment spending: quantile regressions

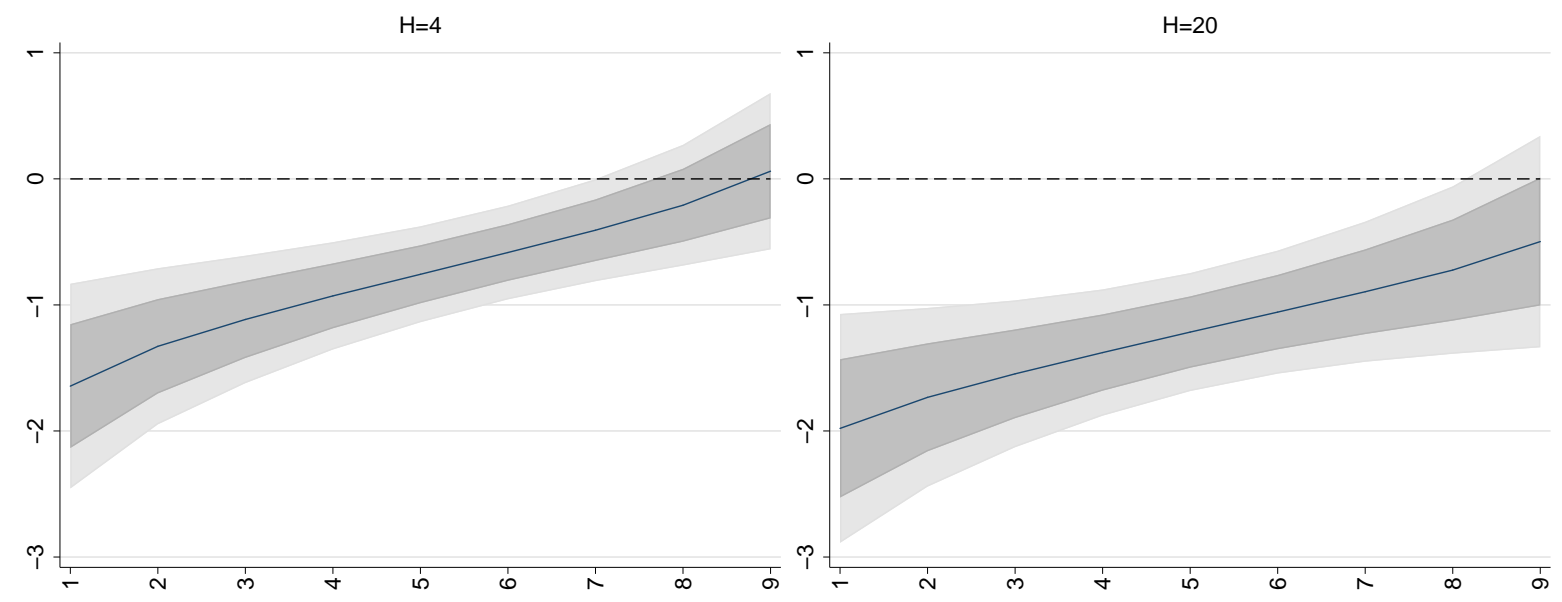

Notes: Cumulative impulse responses of capex to a 10 p.p. increase in corporate debt build-ups up to 20 quarters ahead. The x-axis represents the different percentiles. The dark (light) grey area refers to the 68 (90)\% confidence bands.

\section{$7 \quad$ General equilibrium effects}

This paper has shown that debt booms are associated with declines in future investment growth for financially constrained firms. The results with a linear specification (Figure 6) or when conditioning the sample of firms on financial constraints (Figures 8 and 9) refer to the partial

\footnotetext{
${ }^{18}$ The decline in investment is larger for the $5^{\text {th }}$ percentile - of around $2.2 \%$ - the common metric used in the GaR literature to analyse tail risks.
} 
equilibrium effect of debt booms: the inclusion of time fixed effects or of industry-by-time fixed effects (see Section 8) absorb all general equilibrium forces that operate at the aggregate and industry levels.

In this section I investigate the importance of general equilibrium effects. As I have shown throughout the paper, debt booms when interacted with financial constraints are strongly associated with weaker investment (the partial equilibrium effect). But the total effect of debt booms may not stop there. For instance, weaker investment may result in lower sales and profits since the firm is investing less. In particular, it is possible that weaker investment for a prolonged period of time may lead vulnerable firms to eventually become zombie firms (with low profits and low ICR). Weaker investment and profits may depress aggregate demand, leading to a new round of investment cuts. In addition, zombie firms may have knock-on effects on healthy firms if the rise in non-performing loans of these zombie firms lead banks to tighten corporate lending across-the-board (Caballero et al. 2008, Becker and Ivashina 2014). These may be important general equilibrium effects that I address below.

I resort to the new method developed by Sarto (2018), and Mian et al. (2019), to estimate general equilibrium effects. The idea is that we can obtain general equilibrium estimates by exploiting the variation both at the cross-section unit and at a less granular level (regions, industries, macroeconomic groups, etc.) to which the cross-section unit belongs. The source of variation could be a randomised shock, or an exogenous variable conditional on observables (Mian et al. 2019). In this paper, the past accumulation of debt falls into the latter category. Moreover, it is important to have three layers of aggregation. In my setup I have the following layers: (i) the cross-section unit $i$ refers to firms; (ii) firms in turn belong to a particular industry $n$, grouped into nine main industries (Table A.1 in Appendix A); and (iii) the third layer is the aggregate non-financial corporate sector (the national level).

I estimate the following specifications:

$$
\begin{gathered}
\Delta_{h} \log \left(I_{i, t+h}\right)=\beta_{h}^{P E} \Delta_{12} D b t_{i, t-1}+\sum_{j=1}^{4} \lambda_{j}^{h} X_{i, t-j}+\eta_{i}^{h}+\zeta_{n, t}^{h}+\epsilon_{i, t+h} \\
\Delta_{h} \log \left(I_{n, t+h}\right)=\left(\beta_{h}^{P E}+\beta_{h}^{G E, \text { industry }}\right) \Delta_{12} \text { Debt } t_{n, t-1}+\sum_{j=1}^{4} \lambda_{j}^{h} X_{n, t-j}+\eta_{n}^{h}+\zeta_{t}^{h}+\epsilon_{n, t+h},
\end{gathered}
$$


where $\beta_{h}^{P E}$ in Equation (8) refers to the partial equilibrium effect of corporate debt build-ups on investment. Industry-by-time fixed effects, $\zeta_{n, t}^{h}$, capture the general equilibrium effect at the industry level. This specification is very similar to the one in Equation (1); the only difference is $\zeta_{n, t}^{h}$, which in the baseline is $\zeta_{t}^{h}$, referring to shocks at the aggregate level. In turn, Equation (9) is estimated at the industry level and includes time fixed effects, $\zeta_{t}^{h}$. I construct industry-level variables by taking weighted averages of the variables by industry, and using firms' total assets as weights. Note that the general equilibrium effect is the sum of the partial equilibrium effect and general equilibrium effects at the industry level, given by $\beta_{h}^{G E}=\beta_{h}^{P E}+\beta_{h}^{G E, \text { industry }}$. By subtracting $\beta_{h}^{P E}$, we obtain a general equilibrium multiplier (Mian et al. 2019).

Similarly, in a second exercise I explore whether general equilibrium effects are stronger for vulnerable firms, since financial constraints prevent firms from smoothing the impact of debt on investment. Specifically, I estimate the following specifications for vulnerable, resilient, and other firms:

$$
\begin{gathered}
\Delta_{h} \log \left(I_{i, t+h}\right)=\sum_{k=1}^{N}\left[\beta_{k, h}^{P E} \Delta_{12} D_{e b t_{i, t-1}}+\sum_{j=1}^{4} \lambda_{j, k}^{h} X_{i, t-j}\right]+\eta_{i}^{h}+\zeta_{n, t}^{h}+\epsilon_{i, t+h} \\
\Delta_{h} \log \left(I_{n, t+h}\right)=\sum_{k=1}^{N}\left[\left(\beta_{k, h}^{P E}+\beta_{k, h}^{G E, \text { industry }}\right) \Delta_{12} \operatorname{Debt}_{n, t-1}+\sum_{j=1}^{4} \lambda_{j, k}^{h} X_{n, t-j}\right]+\eta_{n}^{h}+\zeta_{t}^{h}+\epsilon_{n, t+h}
\end{gathered}
$$

Tables 3 and 4 show the estimated coefficients for the linear specification. Table 4 shows that general equilibrium effects are large: focusing on longer horizons, where the coefficients become statistically significant, I estimate that general equilibrium effects stand at -18.092 after two years, and at -12.623 at the end of five years. For instance, for $h=20$, the estimate from Table 3 translates into a partial equilibrium effect of only $10 \%$ of the total effect $(-1.237 /-12.623)$, while the remaining $90 \%$ is attributable to its general equilibrium multiplier. This suggests that there are important spillovers between firms that result in substantially higher general equilibrium effects relative to the first round of partial effects. The large size of the general equilibrium multiplier is not unique to my paper: in a study of credit multipliers for US and Irish households, Mian et al. (2019), and Acharya et al. (2020), find that the effect of household credit booms come mostly from general equilibrium effects (respectively $80 \%$ and $90 \%$ ).

In Table 5 I investigate the extent to which general equilibrium effects amplify partial 
Table 3: Partial equilibrium effects of corporate debt booms on investment

\begin{tabular}{lcccccc}
\hline \hline & $\mathrm{h}=1$ & $\mathrm{~h}=4$ & $\mathrm{~h}=8$ & $\mathrm{~h}=12$ & $\mathrm{~h}=16$ & $\mathrm{~h}=20$ \\
\hline \multirow{3}{*}{$\beta^{P E}$} & & & & & & \\
& $-0.355^{*}$ & $-0.849^{* * *}$ & -0.513 & $-0.658^{*}$ & $-0.858^{* * *}$ & $-1.237^{* * *}$ \\
& $(0.201)$ & $(0.231)$ & $(0.319)$ & $(0.375)$ & $(0.320)$ & $(0.235)$ \\
& & & & & & \\
\hline Firm FE & Yes & Yes & Yes & Yes & Yes & Yes \\
Industry-time FE & Yes & Yes & Yes & Yes & Yes & Yes \\
Observations & 124,885 & 118,182 & 109,660 & 101,648 & 93,752 & 85,850 \\
Adj. R-squared & 0.178 & 0.250 & 0.315 & 0.370 & 0.420 & 0.469 \\
\hline \hline
\end{tabular}

Notes: Estimates of Eq. 8 at the firm level, where the dependent variable is the cumulative percentage change in the logarithm of real (capex) investment. The coefficient $\beta^{P E}$ has been adjusted to show the change in the dependent variable to a 10 p.p. increase in corporate debt build-ups for a given $h$ horizon. Additional control variables are omitted from the table. Driscoll-Kraay adjusted standard errors shown in parentheses. Asterisks, ***, and ***, denote statistical significance at the $10 \%, 5 \%$, and $1 \%$ levels.

equilibrium effects conditional on a firm being financially constrained. Focusing on $h=8$, the estimates show that general equilibrium effects are as important as partial equilibrium effects for vulnerable firms $(-3.520 /-7.230=50 \%)$, although the general equilibrium effect is not statistically significant. What is also interesting is that $\beta^{G E}$ is negative for resilient firms and for other firms: general equilibrium effects dampen the partial equilibrium effects of debt booms on investment. When we move to a longer horizon of five years, I find that partial equilibrium effects become relatively less strong for vulnerable firms: $75 \%$ of the total effect is attributable to the general equilibrium multiplier, suggesting important negative spillovers effects from rapid build-ups in debt as the horizon increases: $(-11.315+3.093) /-11.315=75 \%$.

Table 4: General equilibrium effects of corporate debt booms on investment

\begin{tabular}{lcccccc}
\hline \hline & $\mathrm{h}=1$ & $\mathrm{~h}=4$ & $\mathrm{~h}=8$ & $\mathrm{~h}=12$ & $\mathrm{~h}=16$ & $\mathrm{~h}=20$ \\
\hline \multirow{3}{*}{$\beta^{G E}$} & & & & & & \\
& -5.737 & -8.166 & $-18.092^{* *}$ & $-16.905^{* *}$ & $-14.212^{* *}$ & $-12.623^{*}$ \\
& $(5.667)$ & $(5.233)$ & $(7.617)$ & $(7.745)$ & $(7.131)$ & $(7.374)$ \\
& & & & & & \\
\hline Industry FE & Yes & Yes & Yes & Yes & Yes & Yes \\
Time FE & Yes & Yes & Yes & Yes & Yes & Yes \\
Observations & 1,215 & 1,188 & 1,152 & 1,116 & 1,080 & 1,044 \\
Adj. R-squared & 0.346 & 0.497 & 0.486 & 0.486 & 0.490 & 0.471 \\
\hline \hline
\end{tabular}

Notes: Estimates of Eq. 9 at the industry level, where the dependent variable is the cumulative percentage change in the logarithm of real (capex) investment. The coefficient $\beta^{G E}$ has been adjusted to show the change in the dependent variable to a 10 p.p. increase in corporate debt build-ups for a given $h$ horizon. Additional control variables are omitted from the table. DriscollKraay adjusted standard errors shown in parentheses. Asterisks, *,**, and ***, denote statistical significance at the $10 \%, 5 \%$, and $1 \%$ levels. 
Table 5: General and partial equilibrium effects based on financial constraints

\begin{tabular}{lcc|cc}
\hline \hline & \multicolumn{2}{c|}{ Partial equilibrium } & \multicolumn{2}{c}{ General equilibrium } \\
& $\mathrm{h}=8$ & $\mathrm{~h}=20$ & $\mathrm{~h}=8$ & $\mathrm{~h}=20$ \\
\hline & & & & \\
$\beta_{\text {Vulnerable }}$ & $-3.520^{* * *}$ & $-3.093^{* * *}$ & -7.230 & $-11.315^{* *}$ \\
& $(1.026)$ & $(0.897)$ & $(10.878)$ & $(5.037)$ \\
$\beta_{\text {Resilient }}$ & $2.689^{* * *}$ & 1.586 & $-22.033^{* *}$ & $-41.129^{* * *}$ \\
& $(0.829)$ & $(1.422)$ & $(9.663)$ & $(10.487)$ \\
$\beta_{\text {Other }}$ & $-0.803^{* * *}$ & $-1.543^{* * *}$ & $-21.186^{* * *}$ & -11.749 \\
& $(0.311)$ & $(0.305)$ & $(6.677)$ & $(7.761)$ \\
& & & & \\
\hline Firm FE & Yes & Yes & No & No \\
Industry-time FE & Yes & Yes & No & No \\
Industry FE & No & No & Yes & Yes \\
Time FE & No & No & Yes & Yes \\
Observations & 109,660 & 85,850 & 1,152 & 1,044 \\
Adj. R-squared & 0.315 & 0.469 & 0.486 & 0.471 \\
\hline \hline
\end{tabular}

Notes: Estimates of Eq. 10 at the firm level (columns 1 and 2) and of Eq. 11 at the industry level (last two columns). The dependent variable is the cumulative percentage change in the logarithm of real (capex) investment. The coefficients have been adjusted to show the change in the dependent variable to a 10 p.p. increase in corporate debt build-ups for a given $h$ horizon. Additional control variables are omitted from the table. Driscoll-Kraay adjusted standard errors shown in parentheses. Asterisks, ${ }^{*},{ }^{* *}$, and ${ }^{* * *}$, denote statistical significance at the $10 \%, 5 \%$, and $1 \%$ levels.

\section{Robustness checks}

I run alternative specifications of Equation (2), taking the split between vulnerable and other firms in Figure 8 as the main benchmark model. The aim is to check the sensitivity of my results to a set of robustness checks. All figures can be found in Section D of the Online Appendix.

\section{$\underline{\text { Alternative dependent variables }}$}

I use capital expenditures divided by the net capital stock, measured with the sum of the net property, plant and equipment (PPE), as an alternative dependent variable. This ratio can be thought of as the investment rate. ${ }^{19}$ Figure D.14 in the Online Appendix shows that the main baseline result - weaker investment for vulnerable firms in the aftermath of debt booms - remains qualitatively unchanged when using the investment rate as the dependent variable.

\section{Additional firm-specific controls}

\footnotetext{
${ }^{19}$ The relationship between capital expenditures (capex) and net capital stock is given by the following: Net PPE $=$ Gross PPE + Capex - cumulative depreciation
} 
To minimise the possibility that the dynamics in investment spending in the aftermath of debt booms is not plagued by an omitted variable bias, I add the following firm-specific variables to the main benchmark model: (i) the log change in real corporate debt, (ii) the log change in real assets, (iii) the log change in real sales, (iv) the share of short-term debt in total debt, and (v) the ICR. The results of this expanded model suggest that adding more firm-specific variables yield exactly the same type of responses: vulnerable firms experience a statistically significant larger fall in investment spending following debt build-ups (Figure D.15).

\section{Build-ups in debt net of liquid assets}

Throughout the paper I have used total debt relative to total assets as the debt build-up variable. Although I am controlling for liquid assets in the regression model, one may argue that it is still possible that some debt build-ups may not be problematic for the firm if they are matched one-to-one by increases in liquid assets. I use debt net of liquid assets, deflated by total assets, as the debt boom variable to check whether my results may be biased by this. The new results in Figure D.16 show that the difference in investment between vulnerable and non-vulnerable firms continues to be statistically significant.

\section{More persistent debt booms}

The literature has also used five-year changes in debt ratios to capture debt booms, particularly those studies that use long series of annual data (Schularick and Taylor 2012, Jordà et al. 2015, 2020, Krishnamurthy and Muir 2017). Although the standard errors are somewhat larger for vulnerable firms than in my baseline, I still find the response of investment for vulnerable firms to be statistically larger for most horizons (Figure D.17).

\section{$\underline{\text { Alternative liquidity indicators }}$}

I have proxied liquidity constraints in the baseline model with current assets (cash and shortterm investments, receivables, inventories, and other current assets) net of current liabilities (short-term debt, accounts payable, income taxes payable, and other current liabilities). This indicator measures the liquidity a firm can tap into, after paying all short-term commitments, to soften the impact of shocks. I redefine vulnerable firms based on two alternative versions of this indicator. The first one only looks at gross current assets, thus not subtracting the short-term liabilities; the second indicator only looks at cash and short-term investments (the 
main components of current assets). I show in Figures D.18 and D.19 that my baseline results remain robust to different measures of liquidity constraints.

\section{Narrower definition of vulnerable firms}

I measure financial constraints (vulnerable firms) with the top tertile of the leverage ratio, and the bottom tertile of the liquidity ratio. These firms are most likely liquidity- and borrowingconstrained, and therefore cut investment spending by significantly more when the accumulation of debt becomes excessive relative to their assets. In an alternative specification, I zoom in on my sample of vulnerable firms and select those that also have an ICR below two. The fraction of vulnerable firms in my sample declines from around $14 \%$ to $6 \%$. While the cut-off point is a bit arbitrary, it is within the range used by the International Monetary Fund in its Global Financial Stability Report to track financial vulnerabilities in NFCs. ${ }^{20}$ There is also some evidence that firms with a low ICR are characterised by high financial distress: they face more constraints to service their debt with internal cash flows and therefore are characterised by lower investment (Palomino et al. 2019). Figure D.20 shows that my baseline results remain strongly robust to this narrower definition of vulnerable firms. Once again, the robustness of my main findings adds more evidence to the view that combining the tails of the distribution of liquid assets and total debt provide a reasonably good picture of financial constraints in the data.

\section{Time-varying industry-specific shocks}

I take into account industry-specific factors that may allow firms within a particular sector to cope better with debt booms. For instance, more capital-intensive industries, such as telecommunications, oil and gas, and large manufacturing firms require initial significant financial resources to finance capital expenditures before they are able to sell their goods and services. An apparent unsustainable debt boom may just reflect a timing mismatch between large investment needs and future revenues. In addition, some sectors, such as utility firms, usually face stable demand and therefore generate a stable amount of income. This may potentially make debt and debt booms less concerning than in other more capital-intensive sectors.

I add industry-by-time fixed effects in Equation (2) to account for possible time-varying industry-specific shocks. I show in Figure D.21 that my baseline results are unaffected when

\footnotetext{
${ }^{20}$ Until very recently, the IMF considered firms with an ICR of less than one as 'weak', and firms with an ICR between one and two as 'vulnerable'. In its April 2019 GFSR the IMF considers firms' debt service capacity as 'low' for an ICR below one, and as 'subpar' for an ICR below three.
} 
accounting for industry-specific shocks. In Section A of the Online Appendix I also run regressions for each one of the nine industries to allow all the coefficients to vary across industries. I find the largest declines in investment to be in transportation, construction, and retail trade, sectors that typically display weaker balance sheets.

Vulnerable firms within each industry

One may also argue that it is better to define vulnerable firms within each industry. The nature of the business in some sectors may allow firms to cope better with high levels of debt, or limited liquid assets. In this context, vulnerable firms are those that belong to the top tertile of the leverage ratio distribution and to the bottom tertile of the liquidity ratio distribution within each industry. Figure D.22 shows that my main results remain robust. The only difference relates to the lack of strong statistical evidence after about four years in the difference in investment responses of vulnerable firms versus non-vulnerable firms.

\section{Pre-GFC period}

I check that whether my results may be driven by the large credit supply shock during the GFC. In fact, this was a period of a substantial credit tightening, both in price and quantity terms, when constrained firms had no other means to finance investment, since external finance was not available, and internal resources were scarce. When I stop the estimation sample in 2007Q4, the investment responses are qualitatively similar to the baseline (Figure D.23). Although the standard errors are slightly larger, I still find a statistically significant difference for most of the horizons between the responses of vulnerable firms and other firms.

\section{$\underline{\text { Business cycle }}$}

Can debt booms be more harmful for investment if the economy is already in a recession (Dell'Ariccia et al. 2016, Jordà et al. 2020, Blickle and Santos 2020)? I account for the state of the business cycle by allowing debt booms to transmit differentially to investment in recessions and expansions. According to the NBER business cycles dates, my sample covers three recessions: 1990Q3-1991Q1, 2001Q1-2001Q4, and 2007Q4-2009Q2. Figure D.24 shows that investment spending of vulnerable firms appears to fall more strongly in the short term during recessions. Yet the difference in point estimates between expansions and recessions is short-lived and subject to large standard errors. 
An alternative way to deal with the business cycle is by considering major tightening episodes in credit supply conditions, as measured with the Senior Loan Officer Opinion Survey (SLOOS) on bank lending practices (data available since 1990Q3). Specifically, I define a dummy that takes the value of one for periods when the net percentage of banks reporting a tightening in standards for C\&I loans to large and middle non-financial firms is above 50\%, and zero otherwise. Figure D.26 shows that vulnerable firms tend to cut investment more up to two years during periods when banks tighten credit substantially. ${ }^{21}$

The results above are aligned with Blickle and Santos (2020), who find that episodes of tight credit conditions, or recessions, amplify the negative correlation between debt overhang and firm investment. What my results show is that these effects persist for about one to two years. For longer horizons, I find that rapid debt build-ups in vulnerable firms are detrimental to the real economy, irrespective of the state of the business cycle: Figures D.25 and D.27 show that investment is weaker for vulnerable firms compared to non-vulnerable firms in both recessions and expansions, and during periods of major tightenings in credit conditions. In a nutshell, financial vulnerabilities - high leverage ratios and low liquid assets - seem to play a greater role in explaining investment growth slowdowns after a debt boom.

In Section B of the Online Appendix, I zoom in on the GFC as a laboratory experiment to study the cross-sectional behaviour of investment during a period of large credit supply shocks. In line with my full sample results, I find that firms that increased their pre-crisis leverage ratio the most experienced a sharper decline in investment during 2007-10. I also find that liquidity played an important role in mitigating the negative shocks: cash-rich firms experienced smaller reductions in investment, in line with recent evidence shown in Joseph et al. (2019). Moreover, I also find that debt booms may affect long-run productivity growth, via lower intangible investment, for vulnerable firms.

\section{Smaller lag structure}

I run the main model with just one lag to test the sensitivity of the four-lag structure that I have adopted for the baseline specification. Figure D.28 shows that the main results remain robust and with similar standard errors.

\footnotetext{
${ }^{21}$ Results are similar if I use credit standards to small firms, or credit standards on commercial real estate loans with construction and land development purposes. In addition, I get a similar picture if I define credit tightening periods when the net percentage of banks tightening credit conditions goes above 10\%, as in Blickle and Santos (2020).
} 


\section{Conclusion}

In this paper I study how investment evolves in the aftermath of firm-specific debt booms. The aim was to shed more light on the lack of consensus in the literature on the effects of corporate debt overhangs. We need four key ingredients to better uncover this association.

First, we need firm-level data to account for the substantial heterogeneity in balance sheets across firms. Studies that use aggregate data, such as Beck et al. (2012), Mian et al. (2017), and Jordà et al. (2020), may mask important relationships between debt overhang and investment, as the micro effects are washed away. Second, I use data since the mid-80s that span several episodes of firm-specific debt build-ups to overcome the challenge of extrapolating findings from a particular episode, such as the GFC. Third, I measure debt overhang through a concept of debt boom - the three-year change in debt to assets - rather than the level of debt. Fourth, I combine leverage and liquid assets to better capture financially constrained firms. Specifically, I define financially constrained/vulnerable firms as those that belong to the top tertile of the leverage ratio, and to the bottom tertile of the net liquid asset ratio.

Using Compustat data for a large panel of US non-financial firms over 1985Q1-2019Q1, my main findings point to a clear link between corporate debt booms and weaker future investment. I rationalise this finding through financial constraints: following a 10 p.p. increase in debt buildups, firms that are more financially vulnerable experience weaker investment growth of 2.5 p.p. after five years relative to unconstrained firms. The difference is larger when I compare these firms with unconstrained firms that have low debt and high liquid asset holdings: investment growth of vulnerable firms is roughly 5 p.p. lower after five years. Moreover, using estimates of intangible assets from Eisfeldt et al. (2020), I find that debt booms in financially vulnerable firms are associated not only with weaker future capex growth, but also with weaker intangible capital growth. I also show that vulnerable firms face increased borrowing costs in the aftermath of a debt boom, signalling tighter credit conditions and increased default risk (Krishnamurthy and Muir 2017, Blickle and Santos 2020). This is in line with models with financial constraints that predict that borrowing constraints prevent firms to finance investment spending when the rise in debt becomes unsustainable.

Moreover, I find that the source of financing matters to explain the negative association between debt booms and investment. I find that build-ups in bank loans for vulnerable firms, irrespective of the share of bank debt in total debt, are associated with larger declines in 
investment than build-ups originated in market debt. I argue that this result is consistent with, but goes over and above, the well-established finding in the literature that firms with a higher share of bank debt are more exposed to credit supply shocks (Kashyap et al. 1993, Becker and Ivashina 2014).

I use the new method developed by Sarto (2018), and Mian et al. (2019), to estimate general equilibrium effects by comparing coefficients between a regression at the firm level with another regression at the industry level. I find that general equilibrium effects explain most of the negative association between corporate debt booms and future investment growth: only roughly $10 \%$ of the total effect of debt booms are coming from partial equilibrium effects. This highlights the role that spillovers between firms may have in amplifying partial equilibrium effects of debt booms at the firm-level.

All in all, the central takeaway in this paper supports the view that persistent debt booms ultimately become unsustainable, leading firms who are financially constrained - high debt and low liquid asset holdings - to cut back on investment (Campello et al. 2010, Hoberg and Maksimovic 2015, Giroud and Mueller 2017, Buera and Karmakar 2019, Kalemli-Ozcan et al. 2019, Blickle and Santos 2020).

What lessons can we draw for the COVID-19 crisis? Although the root causes of the ongoing crisis are very different from the previous crises, particularly the GFC, I believe this paper may offer some lessons about the possible implications of debt booms for the real economy. Similarly to previous debt boom episodes, we saw large pre-crisis build-ups in private debt, reaching historically high levels of corporate debt. Furthermore, a large fraction of US corporate debt is now rated $\mathrm{BBB}$, the lowest investment grade rating, while corporate debt rated below investment grade is at an all-time high. It is true that several policy measures, including credit guarantees, the issue of new debt, and the restructuring of existing debt contracts, may have helped firms withstand a severe loss in earnings. But, as a result, a large fraction of firms find themselves with substantially higher leverage than before the COVID-19 shock. In this context, my paper shows that the vulnerabilities in corporates' balance sheets may amplify the ongoing crisis, and delay the recovery: the rapid rise in leverage ratios may leads firms to shift their focus to meeting debt obligations rather than pursuing new investment projects. In addition, some firms may file for bankruptcy, exacerbating the scarring of the COVID-19 shock. If the GFC is any guide, my analysis shows that the accumulation of debt that precedes a large recession may lead firms to cut back on investment and amplify the downturn in economic activity. 


\section{Appendix A: Sample selection and variable definitions}

I use Compustat data (Wharton Research Data Services) for listed non-financial corporations in the United States. I exclude firms in the 'Finance, Insurance and Real Estate' sectors according to the Standard Industrial Classification (SIC) codes ranging from 6000 to 6799 . I use nine main industries, aggregated according to the range of codes shown in Figure A.1.

Table A.1: Industry composition

\begin{tabular}{lc}
\hline \hline Industry & Range \\
\hline Agriculture & $0100-0999$ \\
Mining & $1000-1499$ \\
Construction & $1500-1799$ \\
Manufacturing & $2000-3999$ \\
Transportation* & $4000-4999$ \\
Wholesale Trade & $5000-5199$ \\
Retail trade & $5200-5999$ \\
Services & $7000-8999$ \\
Other & $9900-9999$ \\
\hline \hline \multicolumn{2}{c}{ Notes: *`Agriculture, Forestry and } \\
Fishing'; **'Transportation, Commu- \\
nications, Electric, Gas and Sanitary \\
service'.
\end{tabular}

I follow standard practice in the literature, such as Ottonello and Winberry (2020), and adopt the following procedure to select only US firms in my sample, since in the Compustat dataset there is not a direct way to identify non-US firms. First, I give a score of $50 \%$ if the Compustat's Incorporation Code is foreign. Second, I give a score of $25 \%$ if the company name includes the term 'ADR', i.e. American Depositary Receipts, which means that the stocks of foreign companies can be traded on the US stock exchanges. Third, I give a score of $25 \%$ if the ADR ratio for a particular firm is greater than zero. Finally, I drop firms from the dataset that have a weighted score from the three criteria above that is equal or larger than 0.5 , an indication that they are most likely foreign companies outside of the United States.

I make additional adjustments to the sample by removing the following firm-quarter observations:

- debt-to-asset ratios larger than 10

- net current assets as a fraction of total assets greater than 10 or smaller than -10

- the growth in real sales and in total assets larger than $100 \%$

- acquisitions larger than $5 \%$ of total assets

For the sake of estimating more precisely the fixed effects, I only keep firms that have a minimum of 30 data points for the debt build-up variable and for investment. My final estimation sample covers an unbalanced panel of 4,742 distinct non-financial firms over 1985q12019q1, resulting in 246,835 firm-quarter observations. 
Table A.2: Variable definitions

\begin{tabular}{|c|c|c|}
\hline Variable & Definition & Source \\
\hline Capital expenditures & $\triangle \mathrm{CAPXY}^{a}$ & Compustat \\
\hline Net capital stock & PPENTQ & Compustat \\
\hline Investment ratio & $\Delta$ CAPXY / lagged PPENTQ & Compustat \\
\hline Intangible capital & $\mathrm{k} \_$int_t100 & Eisfeldt et al. (2020) \\
\hline Total debt (book value) & $\mathrm{DLCQ}+\overline{\mathrm{DLTTQ}}$ & Compustat \\
\hline Long-term debt (book value) & DLTTQ & Compustat \\
\hline Short-term debt (book value) & DLCQ & Compustat \\
\hline Bank debt (book value) & Revolving credit + term loans & Capital IQ \\
\hline Market debt (book value) & Total debt - bank debt & Capital IQ \\
\hline Total assets (book value) & ATQ & Compustat \\
\hline Current assets & ACTQ & Compustat \\
\hline Current liabilities & LCTQ & Compustat \\
\hline Net current assets & ACTQ - LCTQ & Compustat \\
\hline Cash & CHEQ & Compustat \\
\hline Net income & NIQ & Compustat \\
\hline Income taxes & TXTQ & Compustat \\
\hline Interest payments & XINTQ & Compustat \\
\hline Depreciation \& amortization & DPQ & Compustat \\
\hline EBITDA & $\mathrm{NIQ}+\mathrm{TXTQ}+\mathrm{XINTQ}+\mathrm{DPQ}$ & Compustat \\
\hline EBIT & $\mathrm{NIQ}+\mathrm{TXTQ}+\mathrm{XINTQ}$ & Compustat \\
\hline ICR & (NIQ + TXTQ + XINTQ) / XINTQ & Compustat \\
\hline Sales & SALEQ & Compustat \\
\hline Bond yield & Volume-weighted average trading yield & TRACE \\
\hline Acquisitions & $\mathrm{AQCY}^{a}$ & Compustat \\
\hline Age & Years from founding dates & Jay Ritter's database \\
\hline HM index & delaycon & Hoberg and Maksimovic (2015) \\
\hline
\end{tabular}

$a$. Transformation from year-to-date to quarterly.

Table A.3: Descriptive statistics

\begin{tabular}{lcccccc}
\hline \hline & $\mathrm{N}$ & mean & $\mathrm{sd}$ & $\mathrm{p} 10$ & $\mathrm{p} 50$ & $\mathrm{p} 90$ \\
\hline$\Delta \log$ real capex & 246,835 & 0.196 & 0.710 & -0.581 & 0.089 & 1.094 \\
log real net capital stock & 246,724 & 3.993 & 2.623 & 0.527 & 4.005 & 7.439 \\
Investment ratio & 246,724 & 0.077 & 0.553 & 0.017 & 0.050 & 0.161 \\
Intangible capital / assets & 230,387 & 0.816 & 12.590 & 0 & 0.532 & 1.724 \\
$\Delta$ Intangible capital / assets & 190,933 & -0.009 & 4.957 & -0.067 & 0 & 0.061 \\
Debt / assets & 246,835 & 0.251 & 0.240 & 0 & 0.228 & 0.514 \\
$\Delta$ log real debt & 215,245 & -0.011 & 0.455 & -0.190 & -0.010 & 0.168 \\
$\Delta_{12}$ Debt / assets & 246,835 & -0.001 & 0.869 & -0.154 & 0 & 0.172 \\
LT debt / assets & 245,989 & 0.206 & 0.215 & 0 & 0.172 & 0.455 \\
ST debt / assets & 242,252 & 0.047 & 0.113 & 0 & 0.014 & 0.122 \\
Bank debt / assets & 112,415 & 0.099 & 0.145 & 0 & 0.036 & 0.289 \\
Market debt / assets & 112,415 & 0.191 & 0.213 & 0 & 0.160 & 0.416 \\
log real assets & 246,835 & 5.466 & 2.175 & 2.591 & 5.471 & 8.309 \\
$\Delta \log$ real assets & 246,832 & 0.009 & 0.110 & -0.067 & 0.003 & 0.078 \\
Current assets / assets & 246,835 & 0.461 & 0.247 & 0.114 & 0.465 & 0.797 \\
Net current assets / assets & 246,835 & 0.222 & 0.266 & -0.032 & 0.202 & 0.552 \\
Cash / assets & 246,582 & 0.138 & 0.179 & 0.005 & 0.063 & 0.393 \\
ICR & 200,158 & 27.994 & 965.280 & -4.718 & 3.833 & 31.927 \\
$\Delta \log$ real sales & 244,817 & 0.013 & 0.190 & -0.178 & 0.014 & 0.200 \\
Acquisitions / assets & 239,970 & 0.001 & 0.009 & 0 & 0 & 0.003 \\
Bond yield & 30,799 & 5.311 & 2.932 & 2.343 & 4.821 & 8.651 \\
Age & 45,555 & 32.628 & 25.856 & 10.000 & 23.000 & 78.000 \\
Delaycon & 119,583 & -0.019 & 0.090 & -0.131 & -0.024 & 0.100 \\
\hline \hline
\end{tabular}

Sources: Capital IQ, Compustat, Eisfeldt et al. (2020), Hoberg and Maksimovic (2015), Jay Ritter's database, and TRACE. 


\section{References}

Acharya, V. V., Bergant, K., Crosignani, M., Eisert, T. and McCann, F. J. (2020), The Anatomy of the Transmission of Macroprudential Policies, NBER Working Papers 27292, National Bureau of Economic Research, Inc.

Acharya, V. V., Gale, D. and Yorulmazer, T. (2011), 'Rollover Risk and Market Freezes', Journal of Finance 66(4), 1177-1209.

Adrian, T., Boyarchenko, N. and Giannone, D. (2019), 'Vulnerable Growth', American Economic Review 109(4), 1263-1289.

Adrian, T., Grinberg, F., Liang, N. and Malik, S. (2021), 'The Term Structure of Growth-atRisk', American Economic Journal: Macroeconomics (forthcoming).

Aikman, D., Bridges, J., Hacioglu Hoke, S., O’Neill, C. and Raja, A. (2019), Credit, capital and crises: a GDP-at-Risk approach, Bank of England working papers 824, Bank of England.

Albuquerque, B. (2019), 'One Size Fits All? Monetary Policy and Asymmetric Household Debt Cycles in U.S. States', Journal of Money, Credit and Banking 51(5), 1309-1353.

Albuquerque, B. and Krustev, G. (2018), 'Debt Overhang and Deleveraging in the US Household Sector: Gauging the Impact on Consumption', Review of Income and Wealth 64(2), 459-481.

Almeida, H., Campello, M. and Weisbach, M. S. (2004), 'The cash flow sensitivity of cash', The Journal of Finance 59(4), 1777-1804.

Anderson, G. and Cesa-Bianchi, A. (2020), Crossing the credit channel: credit spreads and firm heterogeneity, Bank of England working papers 854, Bank of England.

Bacchetta, P., Benhima, K. and Poilly, C. (2019), 'Corporate Cash and Employment', American Economic Journal: Macroeconomics 11(3), 30-66.

Bahaj, S., Foulis, A., Pinter, G. and Surico, P. (2019), Employment and the collateral channel of monetary policy, Bank of England working papers 827, Bank of England.

Barbiero, F., Popov, A. and Wolski, M. (2020), 'Debt overhang, global growth opportunities, and investment', Journal of Banking \& Finance $\mathbf{1 2 0}(\mathrm{C})$.

Bates, T. W., Kahle, K. M. and Stulz, R. M. (2009), 'Why Do U.S. Firms Hold So Much More Cash than They Used To?', The Journal of Finance 64(5), 1985-2021.

Beck, T., Büyükkarabacak, B., Rioja, F. K. and Valev, N. T. (2012), 'Who Gets the Credit? And Does It Matter? Household vs. Firm Lending Across Countries', The B.E. Journal of Macroeconomics 12(1), 1-46.

Becker, B. and Ivashina, V. (2014), 'Cyclicality of credit supply: Firm level evidence', Journal of Monetary Economics 62(C), 76-93.

Belo, F., Gala, V., Salomao, J. and Vitorino, M. A. (2021), 'Decomposing Firm Value', Journal of Financial Economics (forthcoming). 
Bernanke, B. S. and Gertler, M. (1995), 'Inside the Black Box: The Credit Channel of Monetary Policy Transmission', Journal of Economic Perspectives 9(4), 27-48.

Bernanke, B. S., Gertler, M. and Gilchrist, S. (1999), The Financial Accelerator in a Quantitative Business Cycle Framework, in J. B. Taylor and M. Woodford, eds, 'Handbook of Macroeconomics', Handbook of Macroeconomics, Elsevier, chapter 21, pp. 1341-1393.

Blickle, K. S. and Santos, J. A. C. (2020), The Costs of Corporate Debt Overhang, Available at https://ssrn.com/abstract $=3708502$, SSRN.

Buera, F. and Karmakar, S. (2019), Real effects of financial distress: the role of heterogeneity, Bank of England working papers 814, Bank of England.

Caballero, R. J., Hoshi, T. and Kashyap, A. K. (2008), 'Zombie Lending and Depressed Restructuring in Japan', American Economic Review 98(5), 1943-77.

Campello, M., Graham, J. R. and Harvey, C. R. (2010), 'The real effects of financial constraints: Evidence from a financial crisis', Journal of Financial Economics 97(3), 470-487.

Canay, I. A. (2011), 'A simple approach to quantile regression for panel data', The Econometrics Journal 14(3), 368-386.

Cloyne, J., Ferreira, C., Froemel, M. and Surico, P. (2019), Monetary policy, corporate finance and investment, Working Papers 1911, Banco de España Working Papers.

Corrado, C., Hulten, C. and Sichel, D. (2009), 'Intangible capital and U.S. economic growth', Review of Income and Wealth 55(3), 661-685.

Crouzet, N. and Mehrotra, N. R. (2020), 'Small and Large Firms over the Business Cycle', American Economic Review 110(11), 3549-3601.

Cunha, I. and Pollet, J. (2020), 'Why Do Firms Hold Cash? Evidence from Demographic Demand Shifts', Review of Financial Studies 33(9), 4102-4138.

Darmouni, O., Giesecke, O. and Rodnyansky, A. (2020), The Bond Lending Channel of Monetary Policy, CEPR Discussion Papers 14659, C.E.P.R. Discussion Papers.

Dell'Ariccia, G., Igan, D., Laeven, L. and Tong, H. (2016), 'Credit booms and macrofinancial stability', Economic Policy 31(86), 299-355.

Ding, W., Levine, R., Lin, C. and Xie, W. (2021), 'Corporate Immunity to the COVID-19 Pandemic', Journal of Financial Economics 141(2), 802-830.

Driscoll, J. and Kraay, A. (1998), 'Consistent Covariance Matrix Estimation with Spatially Dependent Panel Data', Review of Economics and Statistics 80(4), 549-560.

Durante, E., Ferrando, A. and Vermeulen, P. (2020), Monetary policy, investment and firm heterogeneity, Working Paper Series 2390, European Central Bank.

Ebsim, M., Faria-e-Castro, M. and Kozlowski, J. (2020), Anatomy of Corporate Credit Spreads: The Great Recession vs. COVID-19, Working Papers 2020-035, Federal Reserve Bank of St. Louis. 
Eggertsson, G. and Krugman, P. (2012), 'Debt, Deleveraging, and the Liquidity Trap: A FisherMinsky-Koo Approach', The Quarterly Journal of Economics 127(3), 1469-1513.

Eisfeldt, A. L., Kim, E. and Papanikolaou, D. (2020), Intangible Value, NBER Working Papers 28056, National Bureau of Economic Research, Inc.

Ewens, M., Peters, R. H. and Wang, S. (2019), Measuring Intangible Capital with Market Prices, NBER Working Papers 25960, National Bureau of Economic Research, Inc.

Fahlenbrach, R., Rageth, K. and Stulz, R. M. (2020), 'How Valuable Is Financial Flexibility when Revenue Stops? Evidence from the COVID-19 Crisis', The Review of Financial Studies (forthcoming).

Farre-Mensa, J. and Ljungqvist, A. (2016), 'Do Measures of Financial Constraints Measure Financial Constraints?', Review of Financial Studies 29(2), 271-308.

Fazzari, S. M., Hubbard, R. G. and Petersen, B. C. (1988), 'Financing Constraints and Corporate Investment', Brookings Papers on Economic Activity 19(1), 141-206.

Fort, T. C., Haltiwanger, J., Jarmin, R. S. and Miranda, J. (2013), 'How Firms Respond to Business Cycles: The Role of Firm Age and Firm Size', IMF Economic Review 61(3), 520559.

Gertler, M. (1988), 'Financial Structure and Aggregate Economic Activity: An Overview', Journal of Money, Credit and Banking 20(3), 559-588.

Gertler, M. and Gilchrist, S. (1994), 'Monetary Policy, Business Cycles, and the Behavior of Small Manufacturing Firms', The Quarterly Journal of Economics 109(2), 309-340.

Gilchrist, S. and Zakrajšek, E. (2012), 'Credit Spreads and Business Cycle Fluctuations', American Economic Review 102(4), 1692-1720.

Giroud, X. and Mueller, H. M. (2017), 'Firm Leverage, Consumer Demand, and Employment Losses During the Great Recession', The Quarterly Journal of Economics 132(1), 271-316.

Greenwood, R. and Hanson, S. G. (2013), 'Issuer Quality and Corporate Bond Returns', Review of Financial Studies 26(6), 1483-1525.

Greenwood, R., Hanson, S. G., Shleifer, A. and Sørensen, J. A. (2020), Predictable Financial Crises, NBER Working Papers 27396, National Bureau of Economic Research, Inc.

Grossman, S. J. and Hart, O. D. (1982), Corporate Financial Structure and Managerial Incentives, in 'The Economics of Information and Uncertainty', NBER Chapters, National Bureau of Economic Research, Inc, pp. 107-140.

Hadlock, C. J. and Pierce, J. R. (2010), 'New Evidence on Measuring Financial Constraints: Moving Beyond the KZ Index', The Review of Financial Studies 23(5), 1909-1940.

Hamilton, J. D. (2018), 'Why You Should Never Use the Hodrick-Prescott Filter', Review of Economic and Statistics 100(5), 831-843. 
Hennessy, C. A. (2004), 'Tobin's q, debt overhang, and investment', The Journal of Finance 59(4), 1717-1742.

Hennessy, C. A., Levy, A. and Whited, T. M. (2007), 'Testing Q theory with financing frictions', Journal of Financial Economics 83(3), 691-717.

Hoberg, G. and Maksimovic, V. (2015), 'Redefining Financial Constraints: A Text-Based Analysis', The Review of Financial Studies 28(5), 1312-1352.

Ippolito, F., Ozdagli, A. K. and Perez-Orive, A. (2018), 'The transmission of monetary policy through bank lending: The floating rate channel', Journal of Monetary Economics 95(C), 4971.

Jeenas, P. (2019), Monetary policy shocks, financial structure, and firm activity: A panel approach. mimeo.

Jordà, O. (2005), 'Estimation and Inference of Impulse Responses by Local Projections', The American Economic Review 95(1), 161-182.

Jordà, O., Kornejew, M., Schularick, M. and Taylor, A. M. (2020), Zombies at Large? Corporate Debt Overhang and the Macroeconomy, Technical Report 951, Federal Reserve Bank of New York.

Jordà, O., Schularick, M. and Taylor, A. M. (2013), 'When Credit Bites Back', Journal of Money, Credit and Banking 45(s2), 3-28.

Jordà, O., Schularick, M. and Taylor, A. M. (2015), 'Betting the house', Journal of International Economics 96(S1), S2-S18.

Joseph, A., Kneer, C., van Horen, N. and Saleheen, J. (2019), All you need is cash: corporate cash holdings and investment after the financial crisis, Bank of England working papers 843, Bank of England.

Kalemli-Ozcan, S., Laeven, L. and Moreno, D. (2019), Debt overhang, rollover risk, and corporate investment: evidence from the European crisis, Working Paper Series 2241, European Central Bank.

Kaplan, S. N. and Zingales, L. (1997), 'Do Investment-Cash Flow Sensitivities Provide Useful Measures of Financing Constraints?', The Quarterly Journal of Economics 112(1), 169-215.

Kashyap, A. K., Stein, J. C. and Wilcox, D. W. (1993), 'Monetary Policy and Credit Conditions: Evidence from the Composition of External Finance', American Economic Review 83(1), 7898.

Kindleberger, C. P. (1978), Manias, Panics, and Crashes: A History of Financial Crises, New York Basic Books.

King, R. G. and Levine, R. (1993), 'Finance and Growth: Schumpeter Might Be Right', The Quarterly Journal of Economics 108(3), 717-737. 
Krishnamurthy, A. and Muir, T. (2017), How Credit Cycles across a Financial Crisis, NBER Working Papers 23850, National Bureau of Economic Research, Inc.

Lang, L., Ofek, E. and Stulz, R. M. (1996), 'Leverage, investment, and firm growth', Journal of Financial Economics 40(1), 3-29.

Levine, R. (2005), Finance and Growth: Theory and Evidence, in P. Aghion and S. Durlauf, eds, 'Handbook of Economic Growth', Vol. 1 of Handbook of Economic Growth, Elsevier, chapter 12 , pp. 865-934.

Machado, J. A. and Santos Silva, J. (2019), 'Quantiles via moments', Journal of Econometrics 213(1), 145-173.

Melcangi, D. (2019), Firms' Precautionary Savings and Employment during a Credit Crisis, Staff Reports 904, Federal Reserve Bank of New York.

Mian, A., Sarto, A. and Sufi, A. (2019), Estimating general equilibrium multipliers: With application to credit markets. mimeo.

Mian, A. and Sufi, A. (2010), 'Household Leverage and the Recession of 2007-09', IMF Economic Review 58(1), 74-117.

Mian, A. and Sufi, A. (2011), 'House Prices, Home Equity-Based Borrowing, and the US Household Leverage Crisis', American Economic Review 101(5), 2132-56.

Mian, A., Sufi, A. and Verner, E. (2017), 'Household Debt and Business Cycles Worldwide', Quarterly Journal of Economics 132(4), 1755-1817.

Myers, S. C. (1977), 'Determinants of corporate borrowing', Journal of Financial Economics $\mathbf{5}(2), 147-175$.

Ottonello, P. and Winberry, T. (2020), 'Financial Heterogeneity and the Investment Channel of Monetary Policy', Econometrica 88(6), 2473-2502.

Palomino, F. J., Paolillo, S., Perez, A. and Sanz-Maldonado, G. (2019), The Information in Interest Coverage Ratios of the US Nonfinancial Corporate Sector, FEDS Notes 2019-01-10, Board of Governors of the Federal Reserve System (U.S.).

Rancière, R., Tornell, A. and Westermann, F. (2008), 'Systemic Crises and Growth', The Quarterly Journal of Economics 123(1), 359-406.

Richter, B., Schularick, M. and Wachtel, P. (2021), 'When to lean against the wind', Journal of Money, Credit and Banking 53(1), 5-39.

Sarto, A. (2018), Recovering macro elasticities from regional data. mimeo.

Schularick, M. and Taylor, A. M. (2012), 'Credit Booms Gone Bust: Monetary Policy, Leverage Cycles, and Financial Crises, 1870-2008', American Economic Review 102(2), 1029-61.

Whited, T. M. and Wu, G. (2006), 'Financial Constraints Risk', Review of Financial Studies 19(2), 531-559. 


\title{
ONLINE APPENDIX
}

\section{Corporate debt booms, financial constraints, and the investment nexus}

\author{
Bruno Albuquerque*
}

This appendix is structured as follows. In Section A I replicate some of the regressions from the main paper at the industry level. Section B takes the GFC period as a laboratory experiment to study the cross-sectional behaviour of investment during a period of large credit supply shocks. Section C studies the response of liquid assets in the aftermath of a debt boom. Section D includes several additional figures from robustness checks performed in the main paper.

\section{A: Industry analysis}

I expand the analysis in the main text by looking at the four-digit SIC code sectors. Manufacturing, transportation (which includes communications, electric, gas and sanitary service), and services account for over $80 \%$ of the sample (Table A.1). The distribution of vulnerable firms varies widely across industries. Transportation and mining, for instance, are two sectors where vulnerabilities appear to be more concerning: vulnerable firms account for $46 \%$ and $25 \%$ of all firms in these sectors. In contrast, manufacturing firms tend to be more financially resilient.

Table A.1: Industries by four-digit SIC codes

\begin{tabular}{lccc}
\hline \hline Industry & $\mathbf{N}$ & $\mathbf{\%}$ & \% vulnerable \\
\hline Agriculture* & 839 & 0.4 & 10.0 \\
Mining & 12,734 & 5.8 & 25.0 \\
Construction & 1,790 & 0.8 & 3.0 \\
Manufacturing & 109,177 & 50.1 & 4.7 \\
Transportation** & 35,475 & 16.3 & 46.1 \\
Wholesale Trade & 8,518 & 3.9 & 5.1 \\
Retail trade & 14,839 & 6.8 & 11.8 \\
Services & 33,269 & 15.3 & 10.0 \\
Other & 1,472 & 0.7 & 10.1 \\
\hline \hline
\end{tabular}

Notes: *'Agriculture, Forestry and Fishing'; **'Transportation, Communications, Electric, Gas and Sanitary service’.

Leverage and liquid assets vary substantially across sectors (Figure A.1). Although leverage in 2019Q1 was at historically high levels (compared to median long-term averages) across all

\footnotetext{
*Bank of England and CfM, bruno.albuquerque@bankofengland.co.uk; 20 Moorgate, London, EC2R 6DA, United Kingdom
} 
economic sectors, firms in the transportation, communications, electric, and gas sector ('transp') stand out; this sector also exhibits low ICRs and low liquidity, implying that debt booms have not been accompanied by similar improvements on the asset side of the firms' balance sheets.

Figure A.1: Leverage and liquidity indicators by industry
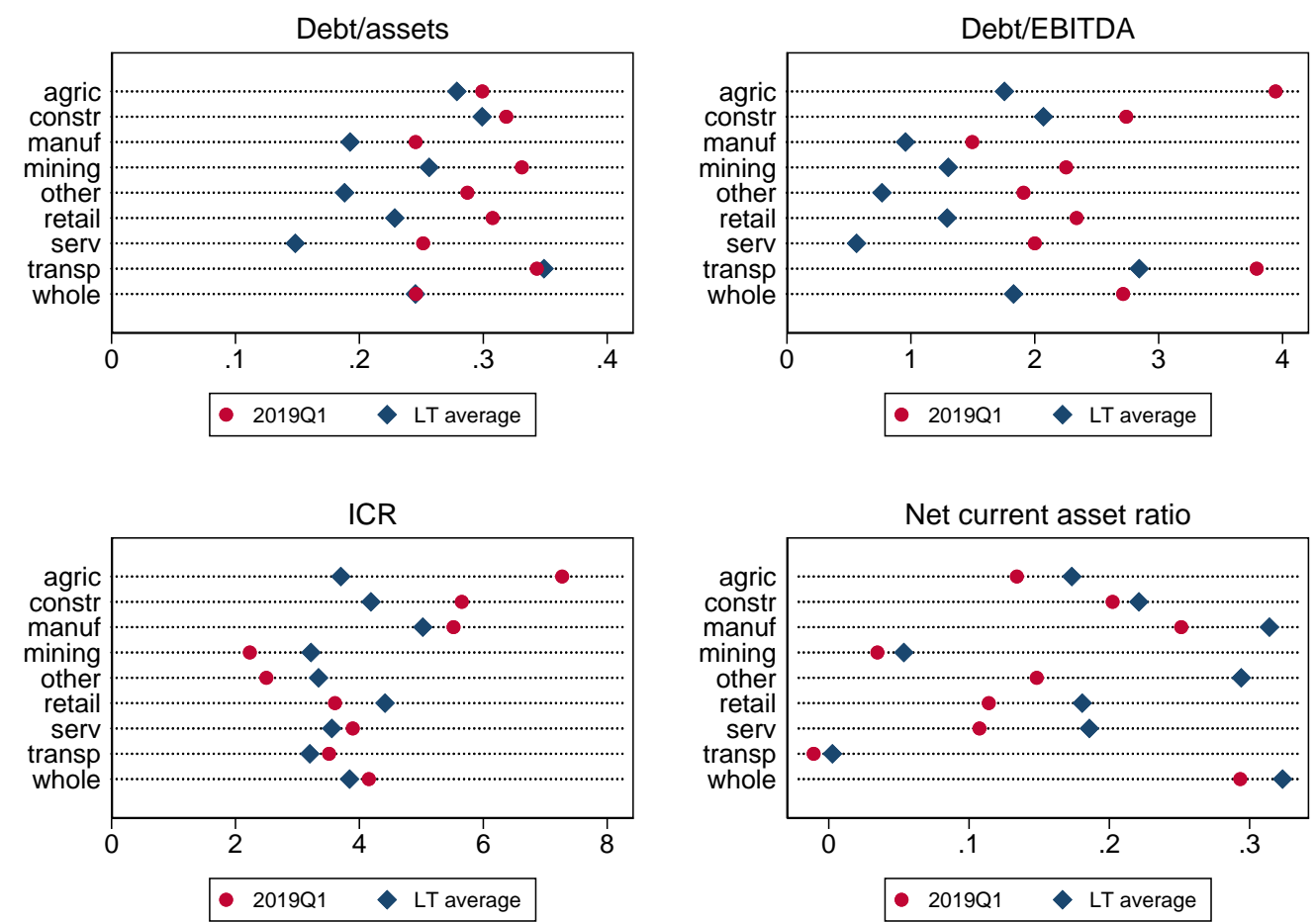

Sources: Compustat, and author's calculations.

Notes: The blue diamonds refer to the median long-term averages of each indicator for each industry, while the red circles indicate the median value for $2019 \mathrm{Q} 1$.

In the main text, I have shown that my results are robust to controlling for time-varying industry-specific shocks. In this section I run two additional exercises to explore further the association between debt booms and investment growth at the sectoral level. First, I run regressions for each one of the nine industries. These new regressions allow all the coefficients to vary across industries. The analysis will in effect explore the within-industry variation in the elasticity of investment spending to debt booms. I show point estimates for vulnerable firms of the elasticity of investment spending growth to a 10 p.p. change in the pace of credit accumulation for three- and five-years ahead (Figure A.2). I find the largest responses in transportation, construction, and retail trade; these are sectors that typically display weaker balance sheets, as shown in Figure A.1. When I compare vulnerable with non-vulnerable firms, I find that vulnerable firms in retail trade and construction experience statistically significant larger declines in investment five years after a debt boom (Figure A.3).

The transportation sector is quite large and heterogeneous: it includes firms in the transportation industry, communications, and energy (gas and electricity). I find a statistically significant link between debt build-ups and investment for both vulnerable and non-vulnerable firms only in the communications sector (Figure A.5). ${ }^{1}$ Firms in this sector have similar balancesheet positions, such as large levels of debt relative to assets, moderate to low liquid assets, and

\footnotetext{
${ }^{1}$ I show the responses for the overall transportation sector in Figure A.4.
} 
small ICRs. This suggests that credit and liquidity constraints may be at play for both groups of firms, despite some firms not falling under my definition of financial constraints. I also find that the response of vulnerable firms is statistically larger compared to non-vulnerable firms only in the energy sector (Figure A.6). This is a sector in which two-thirds of the firms fall into the definition of financial vulnerability explored in this paper, while the remaining firms display relatively robust balance sheets. Finally, I do not find any association between debt booms and investment growth for the sub-category of transportation firms (Figure A.7).

Figure A.2: Impulse responses of vulnerable firms by industry
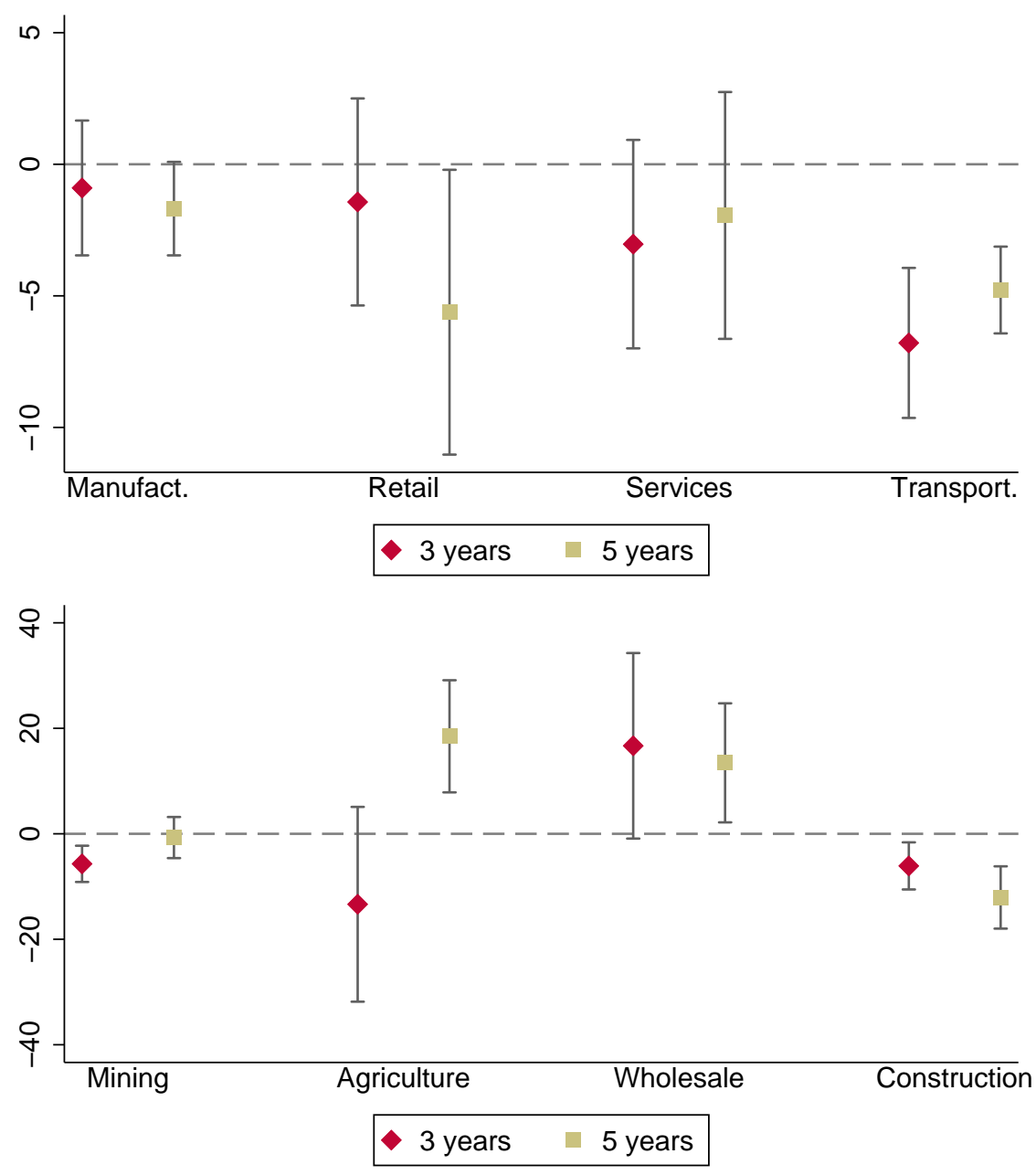

Notes: The red (khaki) diamonds (circle) show the average response after 12 (20) quarters. The vertical lines show the $90 \%$ confidence interval of the estimated coefficients.

In a second exercise, I focus on manufacturing firms to provide more evidence on the negative association between financial constraints and future investment growth. The literature on monetary policy has found that durable goods-producing firms, such as manufacturing and construction, are more interest-rate sensitive and thus respond more to monetary policy (Barth and Ramey 2002, Dedola and Lippi 2005, Durante et al. 2020). Along these lines, and since debt booms are associated with an increase in borrowing costs, it could well be the case that my results are driven by the durability of output and not by financial constraints. If this is the case, I would expect durable goods-producing firms to be associated with weaker investment spending, irrespective of being credit constrained. 
Figure A.3: Differences between the responses of vulnerable firms and other firms
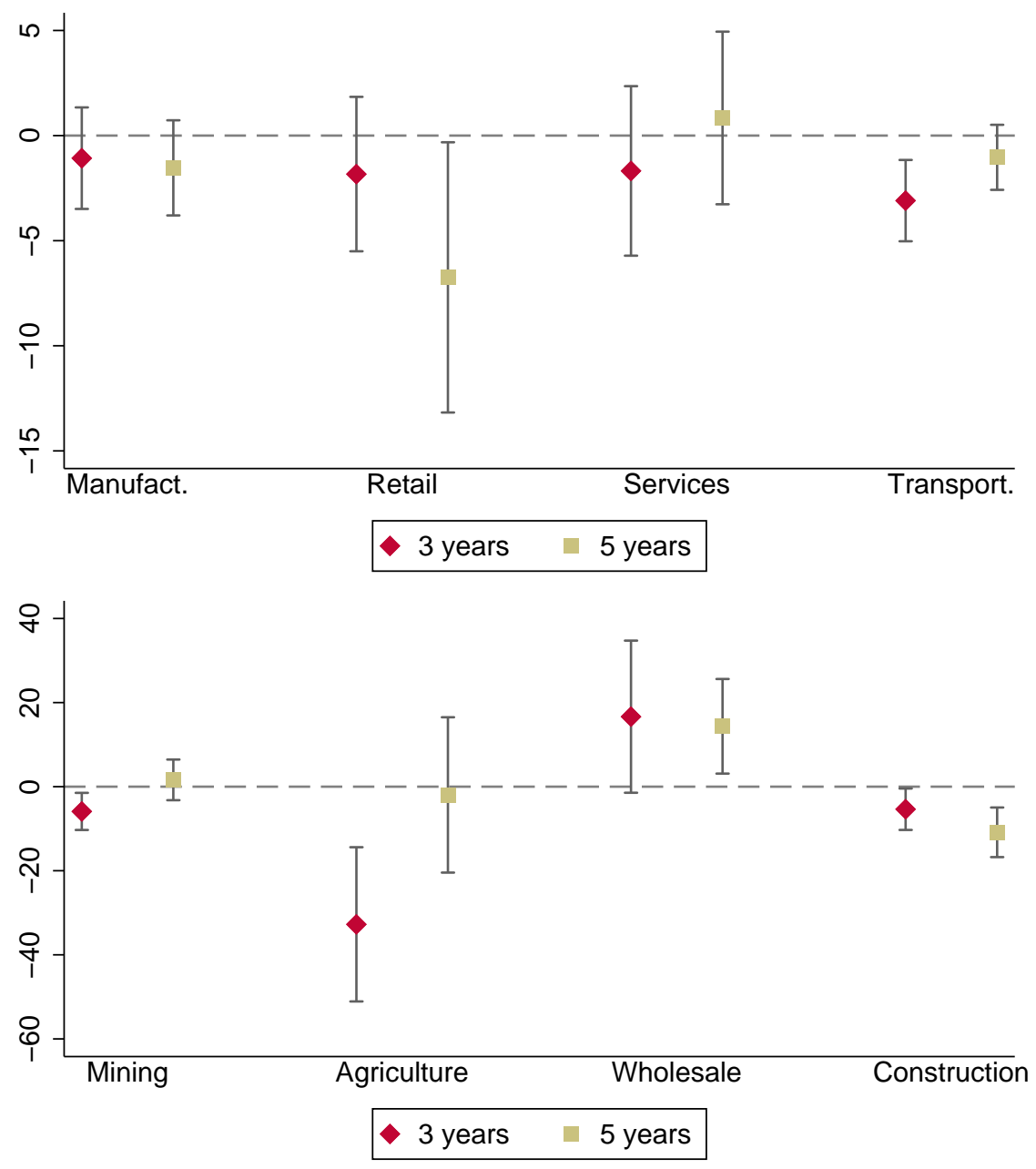

Notes: The red (khaki) diamonds (circle) show the difference in the average response between vulnerable and other firms after 12 (20) quarters. The vertical lines show the 90\% confidence interval of the difference in the estimated coefficients.

Figure A.4: Impulse responses of transportation firms

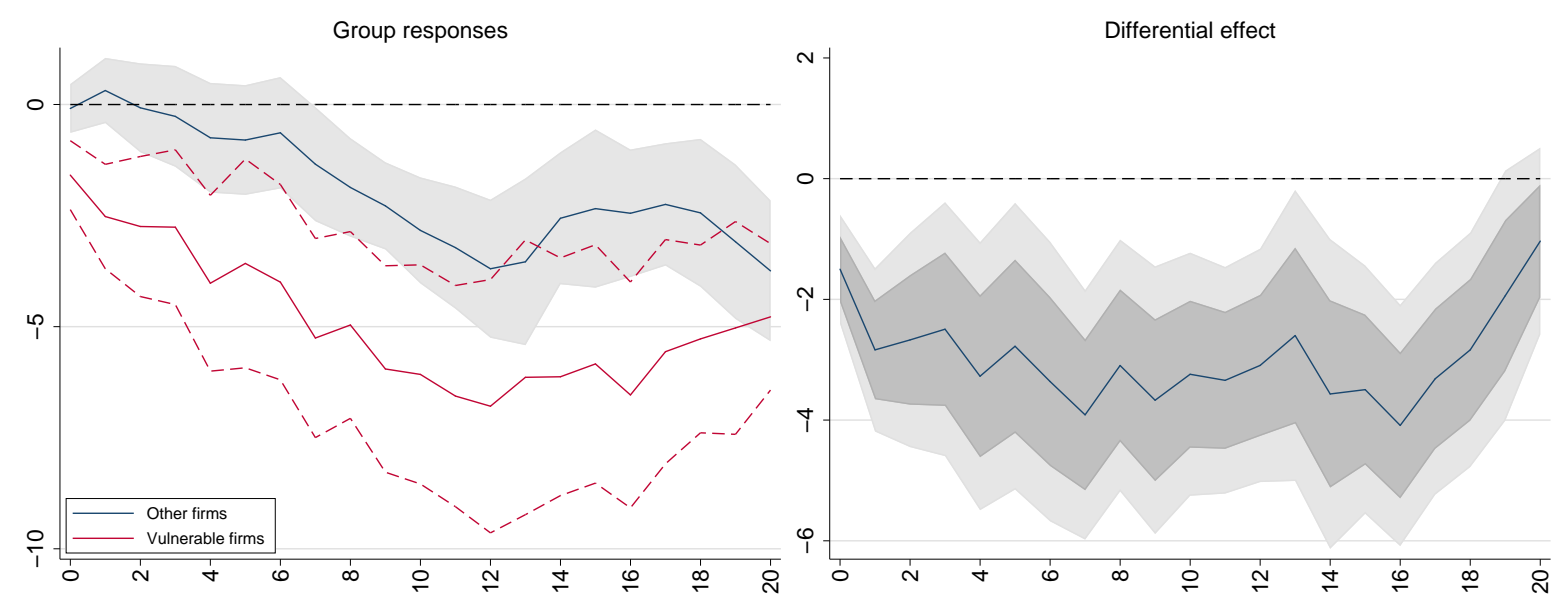

Notes: Cumulative impulse responses of capex to a 10 p.p. increase in corporate debt build-ups up to 20 quarters ahead. The red lines (blue line and grey area) refer to the response of vulnerable (other) firms and associated $90 \%$ confidence bands. The right panel depicts the difference, with the $68 \%$ and $90 \%$ confidence bands, between vulnerable and other firms. 
Figure A.5: Impulse responses of communications firms

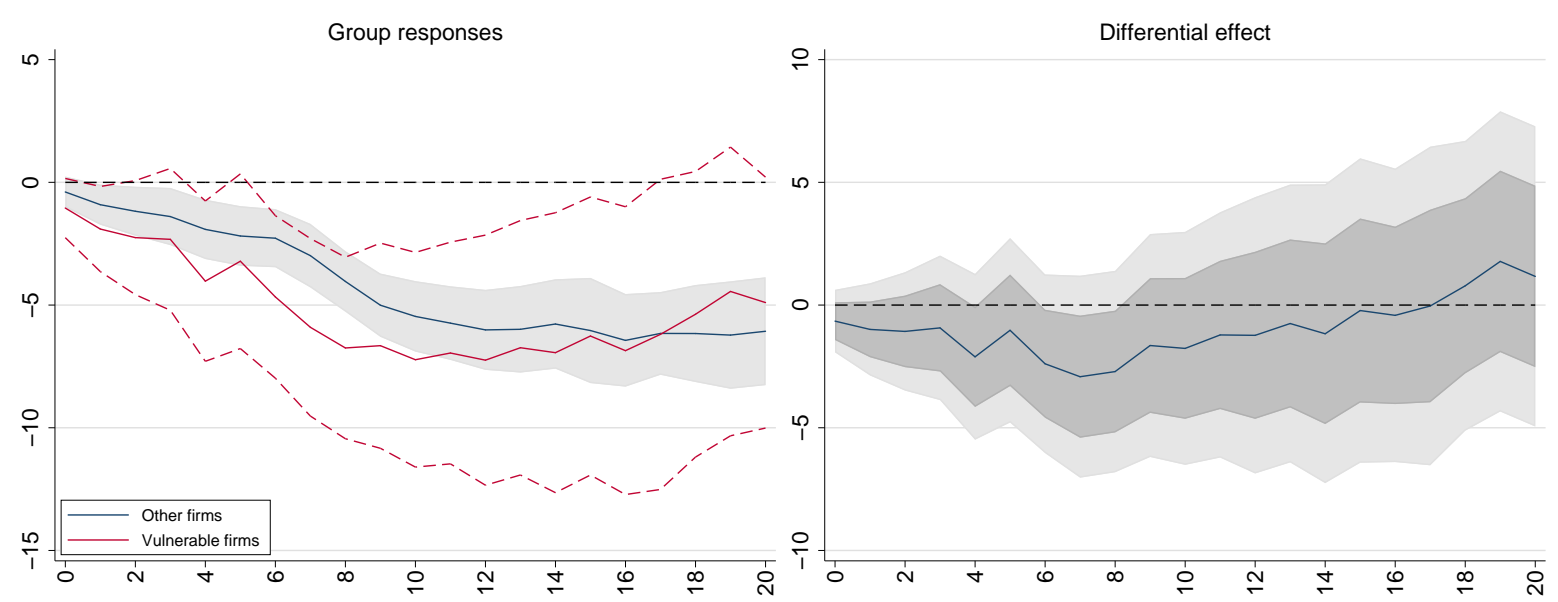

Notes: Cumulative impulse responses of capex to a 10 p.p. increase in corporate debt build-ups up to 20 quarters ahead. The red lines (blue line and grey area) refer to the response of vulnerable (other) firms and associated $90 \%$ confidence bands. The right panel depicts the difference, with the $68 \%$ and $90 \%$ confidence bands, between vulnerable and other firms.

Figure A.6: Impulse responses of energy firms
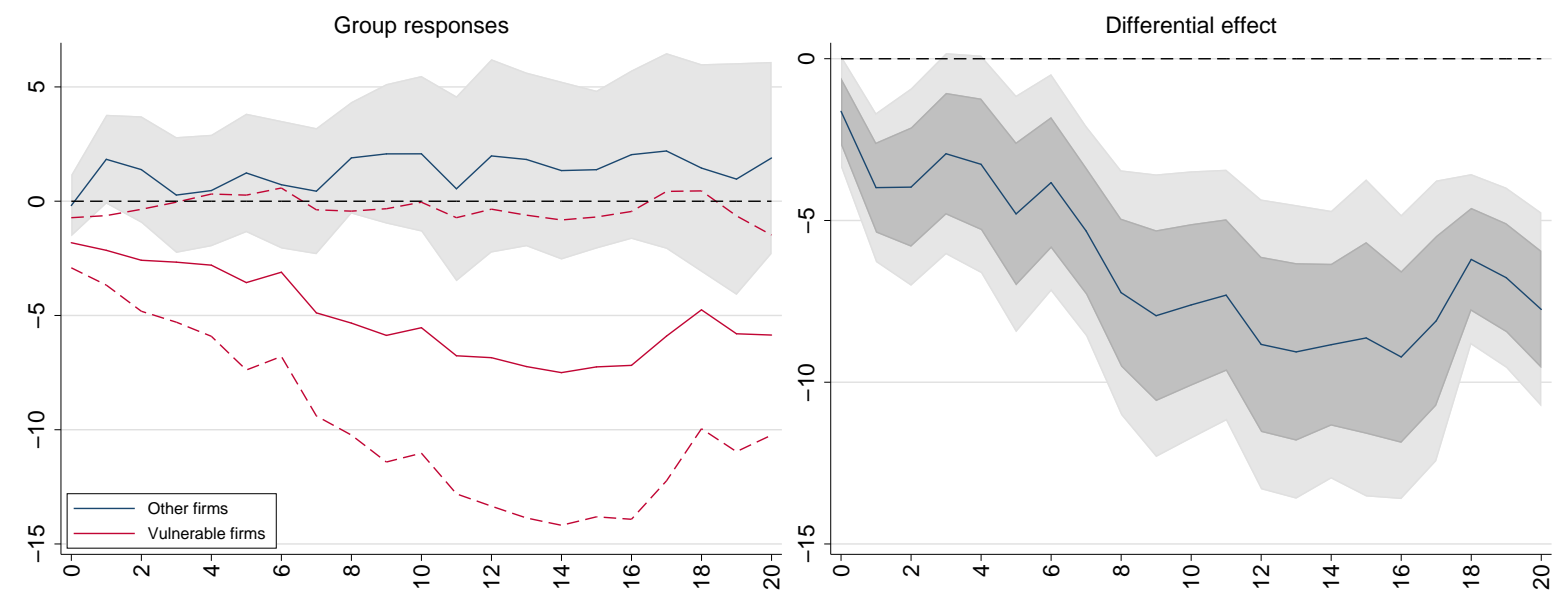

Notes: Cumulative impulse responses of capex to a 10 p.p. increase in corporate debt build-ups up to 20 quarters ahead. The red lines (blue line and grey area) refer to the response of vulnerable (other) firms and associated $90 \%$ confidence bands. The right panel depicts the difference, with the $68 \%$ and $90 \%$ confidence bands, between vulnerable and other firms.

Figure A.7: Impulse responses of transportation sub-category firms
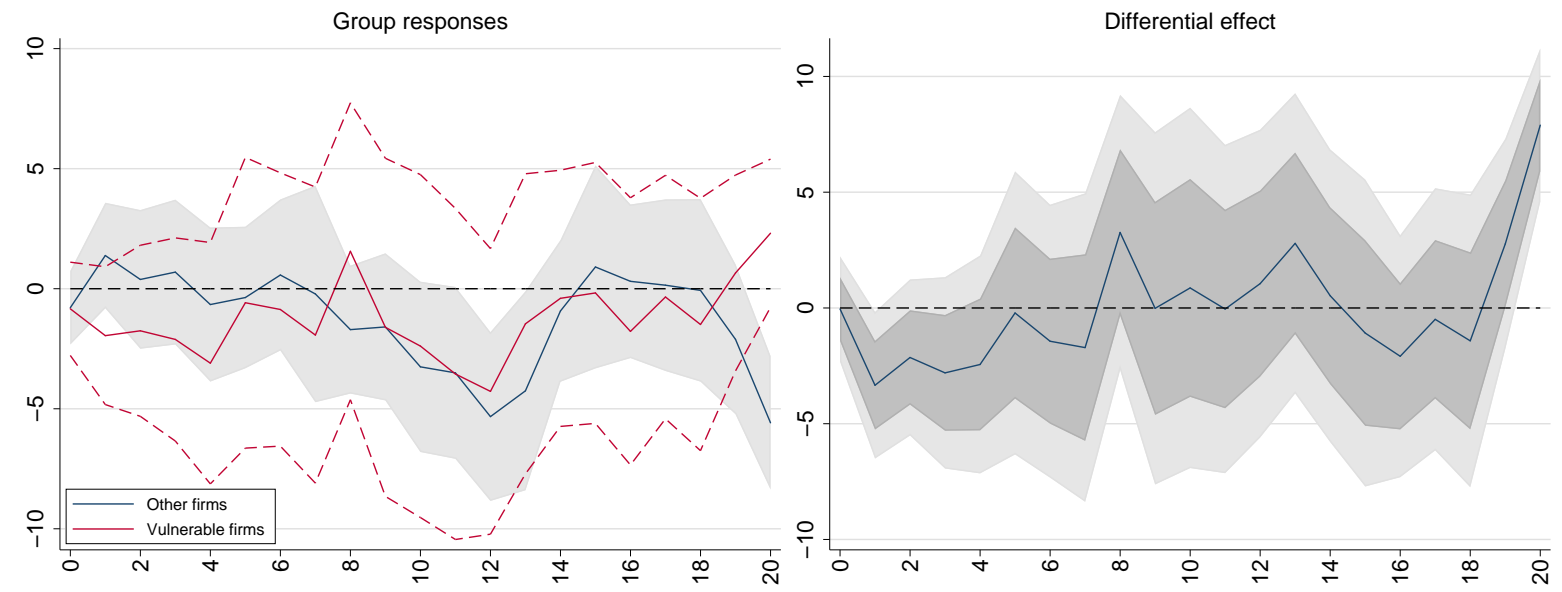

Notes: Cumulative impulse responses of capex to a 10 p.p. increase in corporate debt build-ups up to 20 quarters ahead. The red lines (blue line and grey area) refer to the response of vulnerable (other) firms and associated $90 \%$ confidence bands. The right panel depicts the difference, with the $68 \%$ and $90 \%$ confidence bands, between vulnerable and other firms. 
I put this theory to a test. I split manufacturing firms, representing $50 \%$ of my sample, into durable and non-durable producing industries. ${ }^{2}$ Figure A.8 shows that there is not a discernible difference in the reaction of investment to debt booms between manufacturing firms that produce durable goods and non-durable goods. ${ }^{3}$ Credit and liquidity constraints, not the durability of output, seem to dominate in explaining why firms cut investment spending when facing a debt boom.

Figure A.8: Impulse responses of manufacturing firms: durable vs non-durables

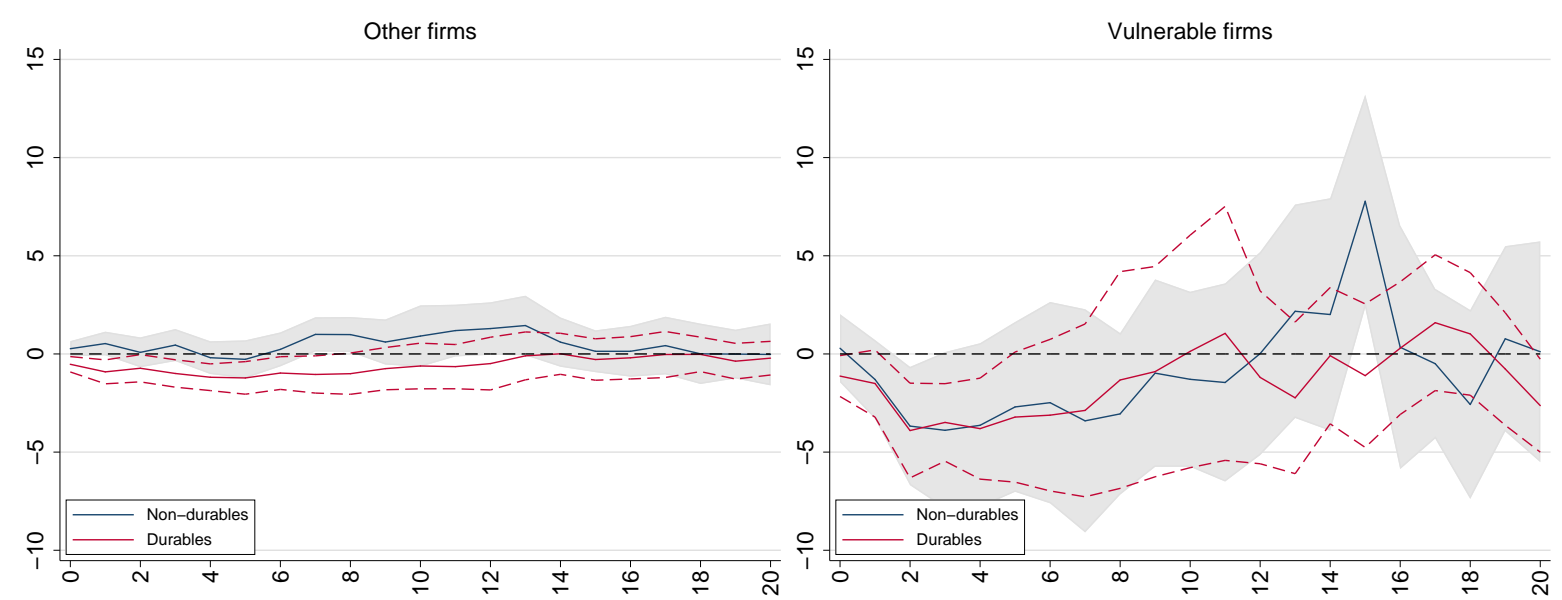

Notes: Cumulative impulse responses of capex to a 10 p.p. increase in corporate debt build-ups up to 20 quarters ahead. The red lines (blue line and grey area) refer to the response of durable (non-durable) goods industries and associated $90 \%$ confidence bands.

\section{B: The large credit supply shock around the GFC}

I now explore the cross-sectional variation in the firms' responses to the large credit supply contraction of the 2007-09 recession. I focus on this period for two main reasons. First, the GFC provides a laboratory experiment for the differential behaviour of firms following a large credit supply shock. The 2007-09 recession deserves special attention as it was by far the largest financial shock since the Great Depression. Second, the GFC may provide us with some insights into what to expect when firms accumulate too much debt during periods of large credit supply shocks. Although, the COVID-19 shock is arguably very different in nature from the GFC, both periods are characterised by large build-ups in debt amid large credit supply shocks. ${ }^{4}$

The macro implications of a firm-specific debt boom preceding a financial crisis may be very

\footnotetext{
${ }^{2}$ I follow Durante et al. (2020) and select durable good-producing firms as those belonging to the following SIC broad categories: 'Lumber and Wood Products', 'Furniture and Fixtures', 'Stone, Clay, Glass and Concrete Products', 'Primary Metal Industries', 'Fabricated Metal Products', 'Industrial Machinery and Equipment', 'Electronic and Other Electric Equipment', 'Transportation Equipment', 'Instruments and Related Products', 'Miscellaneous Manufacturing Industries'.

${ }^{3}$ The results remain robust to adding other non-manufacturing sectors, such as construction, to the set of durable-producing firms.

${ }^{4}$ The GFC was preceded by a large build-up of imbalances in the housing market, and by an unprecedented accumulation of debt by the private sector. The inability of households to pay their mortgages led to massive losses to the financial sector. In turn, the reduction in credit supply that ensued reduced aggregate demand further. Households' and banks' balance sheets, amid a context of poorly capitalised banks, amplified the price re-valuation in the real estate sector (Brunnermeier and Krishnamurthy 2020). In turn, the 2020 crisis is rooted in a health shock that subsequently led to supply and demand shocks, as social distancing measures and several lockdowns were put in place in many parts of the world.
} 
different depending on how firms use the accumulated debt. For instance, if a firm decides to allocate debt to productive investment, both capital expenditures or intangible investment, this could act as a countercyclical force during a recession; but if the firm decides to pay off debt or increase liquid asset holdings - even if it can increase the financial resilience of the firm - I would expect the fall in aggregate demand to amplify the recession. I run cross-sectional regressions to shed light on firms' balance sheet behaviour during the GFC for a given amount of debt accumulated pre-crisis. More specifically, I run the following regression:

$$
\Delta Y_{i}^{07-10}=\alpha+\beta_{1} \Delta Y_{i}^{04-07}+\beta_{2} \Delta D e b t_{i}^{04-07}+\beta_{3} Z_{i}^{07}+\zeta_{j}+\epsilon_{i},
$$

where $Y_{i}^{07-10}$ is the cumulative change between $2007 \mathrm{q} 4$ and $2010 \mathrm{q} 4$ for firm $i$ in the following variables: (i) capital stock (tangible investment), (ii) intangible capital, (iii) liquid assets, (iv) acquisitions, and (v) total debt. I divide all variables by total assets, and then standardise them to make it easier to interpret the coefficients. The coefficient of interest is $\beta_{2}$, which measures the association between the rise in leverage in the three years preceding the crisis. Since all variables are standardised, I will interpret $\beta_{2}$ as the standard deviation change in the dependent variable between 2007q4 and 2010q4 from a one-standard deviation increase in the change in the debt-to-asset ratio between $2004 \mathrm{q} 4$ and $2007 \mathrm{q} 4$. I add a set of variables $Z_{i}$ to control for the balance sheet position of firms at the end of 2007, namely the stock of liquid assets, leverage, and the log of total assets (similar to the main baseline model used throughout this paper). I also include the pre-crisis change in the dependent variable $\left(Y_{i}^{04-07}\right)$ to control for possible reversion to the mean effects. Finally, $\zeta_{j}$ refers to industry-specific dummies.

In Table B.1 I show the coefficients when using the 2007-10 change in the capital stock divided by total assets as the dependent variable. One of the main findings that emerges is that firms that increased their pre-crisis leverage ratio by one standard deviation above the sample mean experienced a sharper reduction in the capital stock ratio during the GFC: one standard deviation of capital stock to assets is roughly $25 \%$ over the full sample, implying that the coefficient of -0.07 translates into a 1.8 p.p. decline in the capital stock ratio.

Moreover, I do not find that the level of the leverage ratio in 2007q4 is associated with larger cuts in investment during the recession, which is at odds with recent literature (Buera and Karmakar 2019, Kalemli-Ozcan et al. 2019, Blickle and Santos 2020). My results suggest, however, that it is the debt accumulated pre-crisis, not the level of debt at one point in time, that explains why some firms cut investment by more than others. This argument aligns well with Dell'Ariccia et al. (2016)'s findings that a rapid rise in corporate debt during good times make firms vulnerable to a sudden change in economic conditions, triggering deleveraging and leading to weaker investment down the road.

But the coefficient on liquid assets held at the end of 2007 is highly statistically significant, suggesting that liquidity played a role in allowing cash-rich firms to invest more (or disinvest less) than cash-poor firms during the GFC. This result is in line with (Joseph et al. 2019), who find that UK firms that entered the GFC with larger cash holdings managed to invest more during the recession and recovery. I also find that larger firms cut investment less. In contrast, I do not find any statistical association between the pre-crisis share of bank debt or short-term debt in total debt and investment growth. Note, however, that the sample size is 
somewhat smaller, complicating the comparability of the results. Finally, I also do not find that investment has a non-linear association between debt accumulated pre-crisis for different levels of the liquid asset position or leverage ratio in 2007 (rows with interaction terms in the table).

Table B.1: Regression estimates: $\Delta$ Investment ratio $^{07-10}$

\begin{tabular}{|c|c|c|c|}
\hline & $(1)$ & $(2)$ & $(3)$ \\
\hline$\Delta$ Debt $^{04-07}$ & $\begin{array}{c}-0.070^{* * *} \\
(0.016)\end{array}$ & $\begin{array}{c}-0.072^{* * *} \\
(0.016)\end{array}$ & $\begin{array}{c}-0.090^{* * *} \\
(0.029)\end{array}$ \\
\hline Liq. asset ratio ${ }^{07}$ & $\begin{array}{c}0.193^{* * *} \\
(0.038)\end{array}$ & $\begin{array}{c}0.223^{* * *} \\
(0.051)\end{array}$ & $\begin{array}{c}0.195^{* * *} \\
(0.038)\end{array}$ \\
\hline Debt to assets ${ }^{07}$ & $\begin{array}{l}0.052 \\
(0.043)\end{array}$ & $\begin{array}{l}0.083^{*} \\
(0.050)\end{array}$ & $\begin{array}{l}0.062 \\
(0.050)\end{array}$ \\
\hline $\log (\text { real assets })^{07}$ & $\begin{array}{c}0.107^{* * *} \\
(0.035)\end{array}$ & $\begin{array}{c}0.139^{* * *} \\
(0.048)\end{array}$ & $\begin{array}{c}0.106^{* * *} \\
(0.034)\end{array}$ \\
\hline Bank debt share ${ }^{07}$ & & $\begin{array}{l}0.022 \\
(0.034)\end{array}$ & \\
\hline Short-term debt share ${ }^{07}$ & & $\begin{array}{l}0.015 \\
(0.034)\end{array}$ & \\
\hline$\Delta$ Debt $^{04-07 *}$ Liq. asset ratio ${ }^{07}$ & & & $\begin{array}{l}-0.015 \\
(0.016)\end{array}$ \\
\hline$\Delta$ Debt $^{04-07 *}$ Debt to $\operatorname{assets}^{07}$ & & & $\begin{array}{l}-0.010 \\
(0.024)\end{array}$ \\
\hline$\Delta$ Lagged dep. variable ${ }^{07-10}$ & $\begin{array}{c}-0.109 * * * \\
(0.038)\end{array}$ & $\begin{array}{c}-0.070^{*} \\
(0.041)\end{array}$ & $\begin{array}{c}-0.107^{* * *} \\
(0.038)\end{array}$ \\
\hline Observations & 1,667 & 1,310 & 1,667 \\
\hline Adjusted R-squared & 0.058 & 0.054 & 0.058 \\
\hline
\end{tabular}

Notes: Regression estimates of Equation (1), where the dependent variable is the cumulative change in the capital stock ratio from 2007q4 to 2010q4. The constant and the industry dummies are omitted. Robust heteroskedastic standard errors in parentheses. Asterisks, ${ }^{*}, * *$, and $* * *$, denote statistical significance at the $10 \%$, $5 \%$, and $1 \%$ levels.

I now investigate how the pre-crisis change in the leverage ratio is associated with the other dependent variables, namely the total debt ratio, intangible investment ratio, liquid asset ratio, and acquisitions ratio. For ease of exposition, I show coefficients $\beta_{2}$ and associated $90 \%$ confidence intervals for each dependent variable in Figure B.1. In the upper left panel, I find that the rise in pre-crisis leverage is associated wiht subsequent deleveraging, in line with the view that firms had to restore their leverage ratios to more sustainable levels.

Although I also find that the pre-crisis increase in leverage is associated with declines in intangible investment, liquid assets and acquisitions, they lack statistical support at the $90 \%$ confidence level. The other panels in Figure B.1 highlight the differential responses across firms with different financial vulnerabilities. In particular, I find that the negative association between the pre-crisis boom and the decline in investment and in debt during the GFC is driven by vulnerable firms and other firms, not resilient firms. This is in line the full sample results in previous sections. My results also show that vulnerable firms also cut back on intangible investments, which makes total investment fall further relative to all the other firms in the dataset. 
Figure B.1: Response of investment growth to a change in the leverage ratio (in pp)
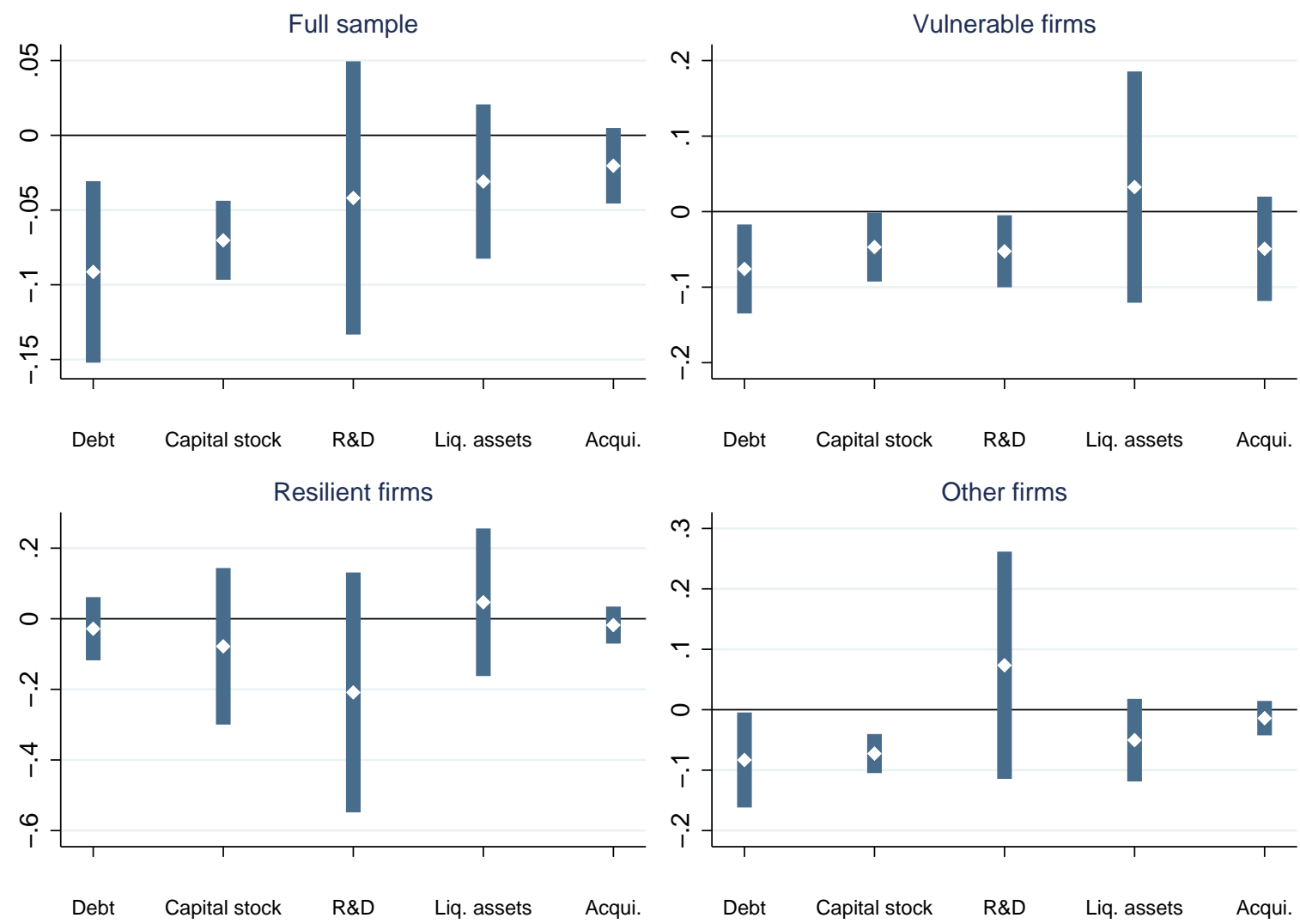

Notes: Point estimates of a regression of the cumulative 2007-10 change in selected variables, shown in the x-axis, on the cumulative 2004-07 change in the leverage ratio. The blue bars refer to the $90 \%$ confidence bands. Coefficients have been standardised to make them comparable across columns.

\section{C: The response of liquid assets}

We have seen that firms that accumulate debt at a faster pace than their assets for a long period of time tend to experience weaker future investment growth. But if investment falls in the aftermath of a debt boom, it is still possible that firms may channel part of the debt raised to increasing liquid asset holdings. The general view in the literature is that financially constrained firms tend to build up cash reserves for precautionary reasons to cushion the impact of future credit supply shocks (Almeida et al. 2004, Bates et al. 2009, Campello et al. 2010, Bacchetta et al. 2019, Joseph et al. 2019, Melcangi 2019, Cunha and Pollet 2020). There is some recent evidence that constrained firms may then increase their liquid assets during episodes of credit supply shocks (Melcangi 2019), or at least keep them higher for longer (Cunha and Pollet 2020). ${ }^{5}$

I use the cumulative change in the liquid asset ratio as the dependent variable in Equation (2) in the main paper with the breakdown of firms into vulnerable, resilient, and other firms. I find that only vulnerable firms seem to decrease their liquid assets following a debt boom

\footnotetext{
${ }^{5}$ Cunha and Pollet (2020) document that financially constrained firms build their cash reserves using internal sources and that they start saving earlier and keep high cash levels longer. Unconstrained firms instead rely on external financing to both invest and build cash reserves, requiring them to save less and allowing them to incur lower costs of carry.
} 
(Figure C.1). In turn, resilient firms tend to increase liquid assets following episodes of rapid accumulation of debt. The difference in the response of liquid assets between resilient firms and vulnerable firms is statistically significant for about three years. Results remain qualitatively robust if I instead use cash to assets as the measure of liquidity, as in Joseph et al. (2019) Figure C.2.

Figure C.1: Impulse responses of net current asset ratio
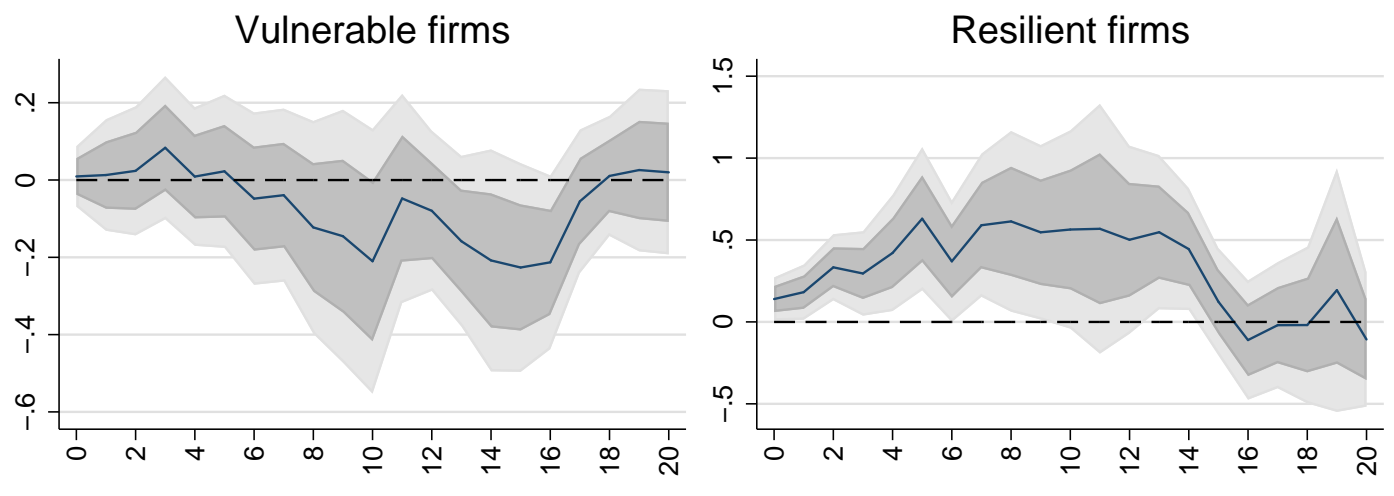

Other firms
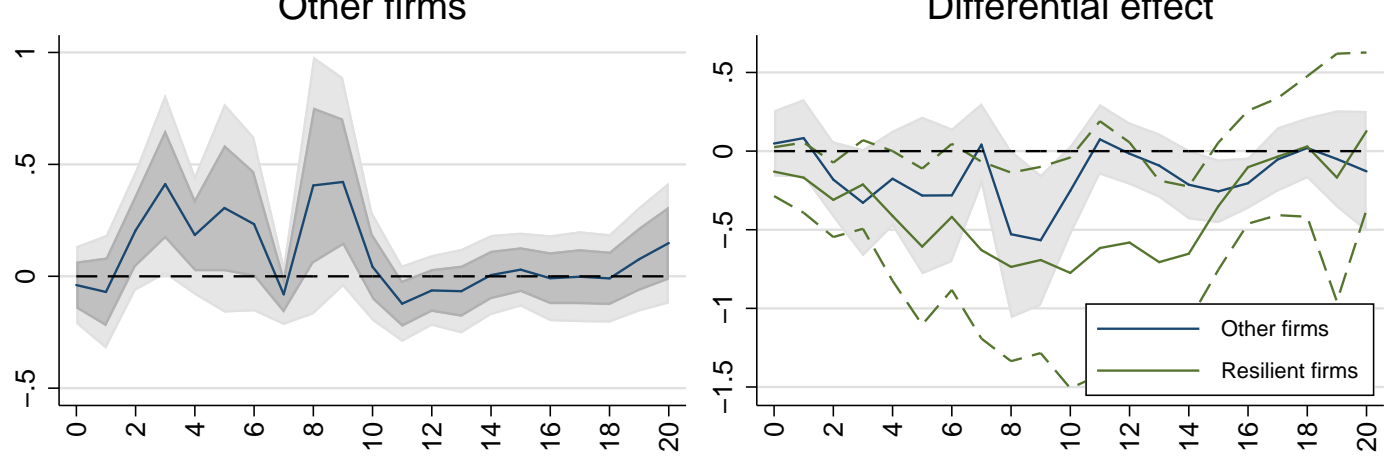

Notes: Cumulative impulse responses of the net current asset ratio to a 10 p.p. increase in corporate debt build-ups up to 20 quarters ahead. Each panel shows the average response and associated $68 \%$ and $90 \%$ confidence bands for vulnerable, resilient, and other firms. The bottom-right panel depicts the difference, with $90 \%$ confidence bands, between the responses of vulnerable and resilient firms (green lines), and between vulnerable and all other firms (blue line and grey area).

Overall, I find some supporting evidence for the view that constrained firms tend to burn through a large portion of their liquid assets during periods of negative credit supply shocks (Campello et al. 2010). The decline in liquid assets of vulnerable firms in the aftermath of debt booms may reflect the need to tap into liquidity to minimise the reduction in investment due to binding credit constraints. In contrast, I find that resilient firms tend to strengthen their liquid asset position following debt booms - presumably for precautionary reasons and to prevent them from becoming constrained (Melcangi 2019). Although this is not conclusive, I conjecture that the fall in investment for vulnerable firms could have been larger, had they increased their liquid assets along the dynamics observed in unconstrained firms. 
Figure C.2: Impulse responses of cash to assets
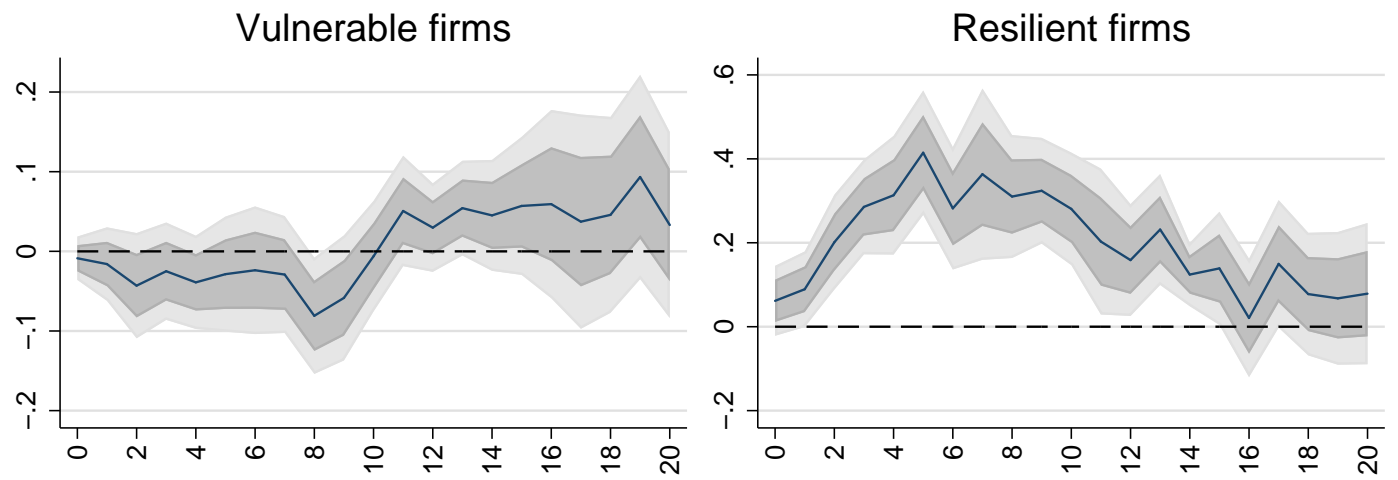

Other firms

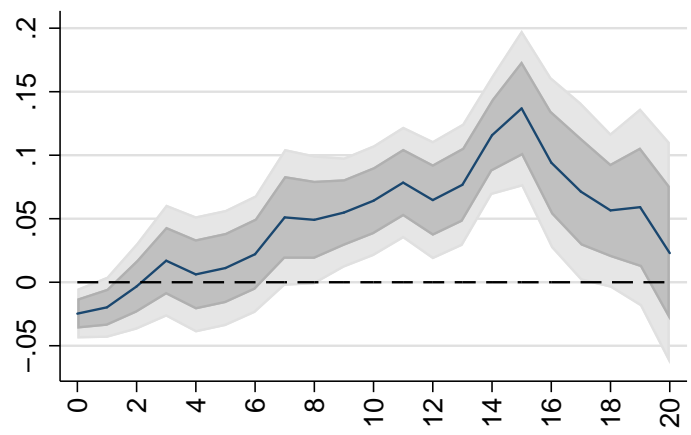

Differential effect

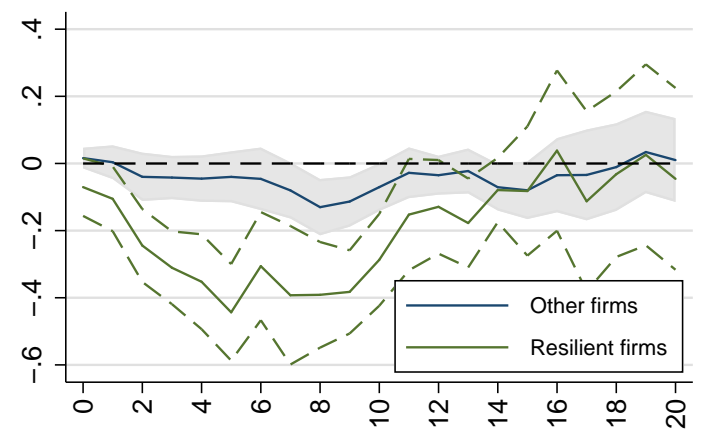

Notes: Cumulative impulse responses of the cash to asset ratio to a 10 p.p. increase in corporate debt build-ups up to 20 quarters ahead. Each panel shows the average response and associated $68 \%$ and $90 \%$ confidence bands for vulnerable, resilient, and other firms. The bottom-right panel depicts the difference, with $90 \%$ confidence bands, between the responses of vulnerable and resilient firms (green lines), and between vulnerable and all other firms (blue line and grey area).

\section{D: Additional figures}

Figure D.1: Impulse responses of corporate bond yields to corporate debt build-ups

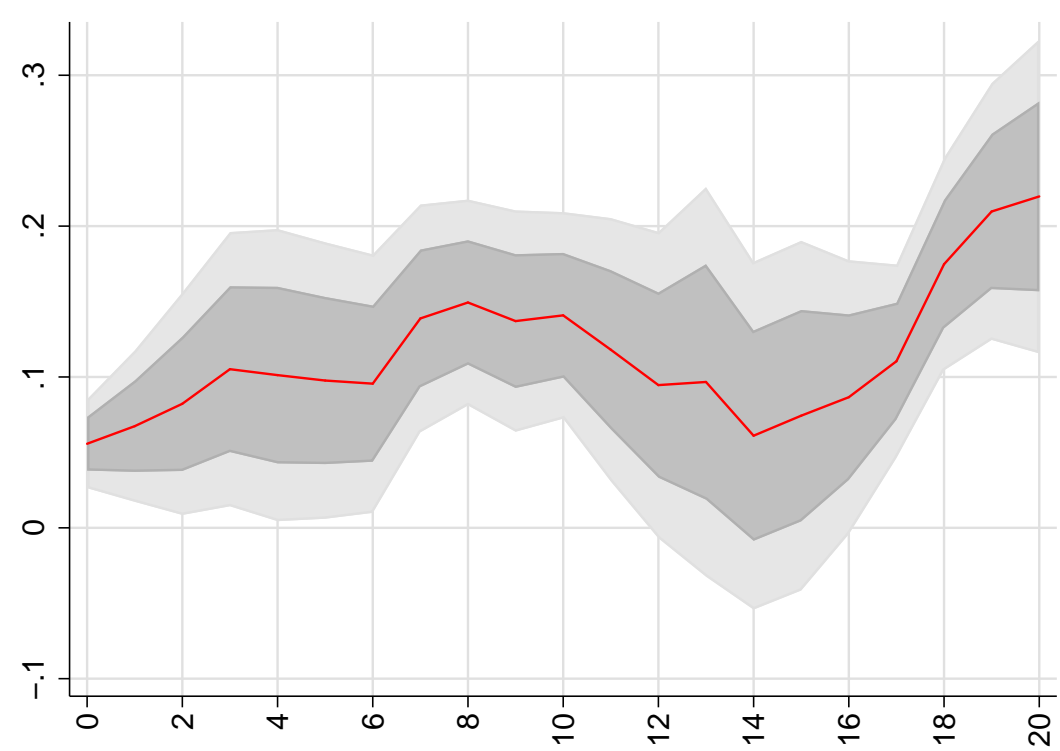

Notes: Cumulative impulse responses of corporate bond yields to a 10 p.p. increase in corporate debt build-ups up to 20 quarters ahead. The dark (light) grey area refers to the $68(90) \%$ confidence bands. 
Figure D.2: Impulse responses of real GDP with aggregate FoF data

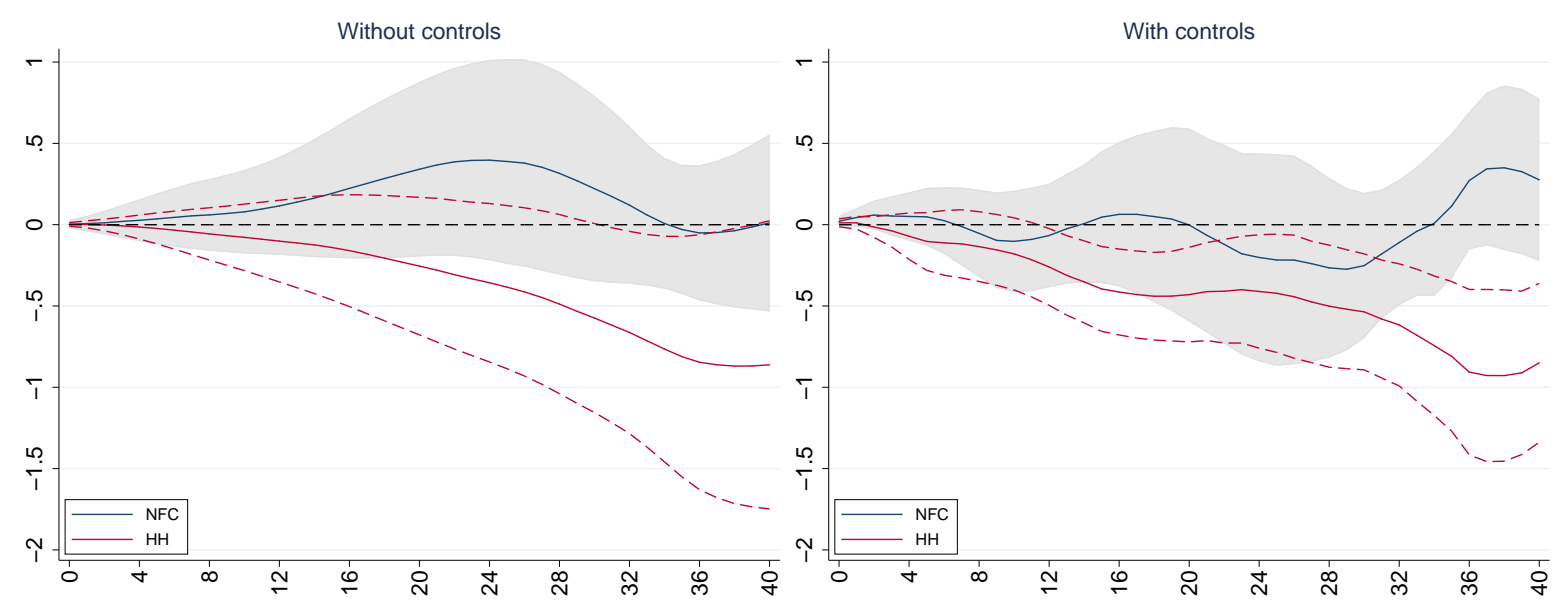

Notes: Cumulative impulse responses to a 1 p.p. increase in debt build-ups in the household and NFC sectors up to 20 quarters ahead. The grey area and dashed red lines refer to the $90 \%$ confidence bands.

Figure D.3: Impulse responses of real GDP with aggregate FoF data excluding the GFC
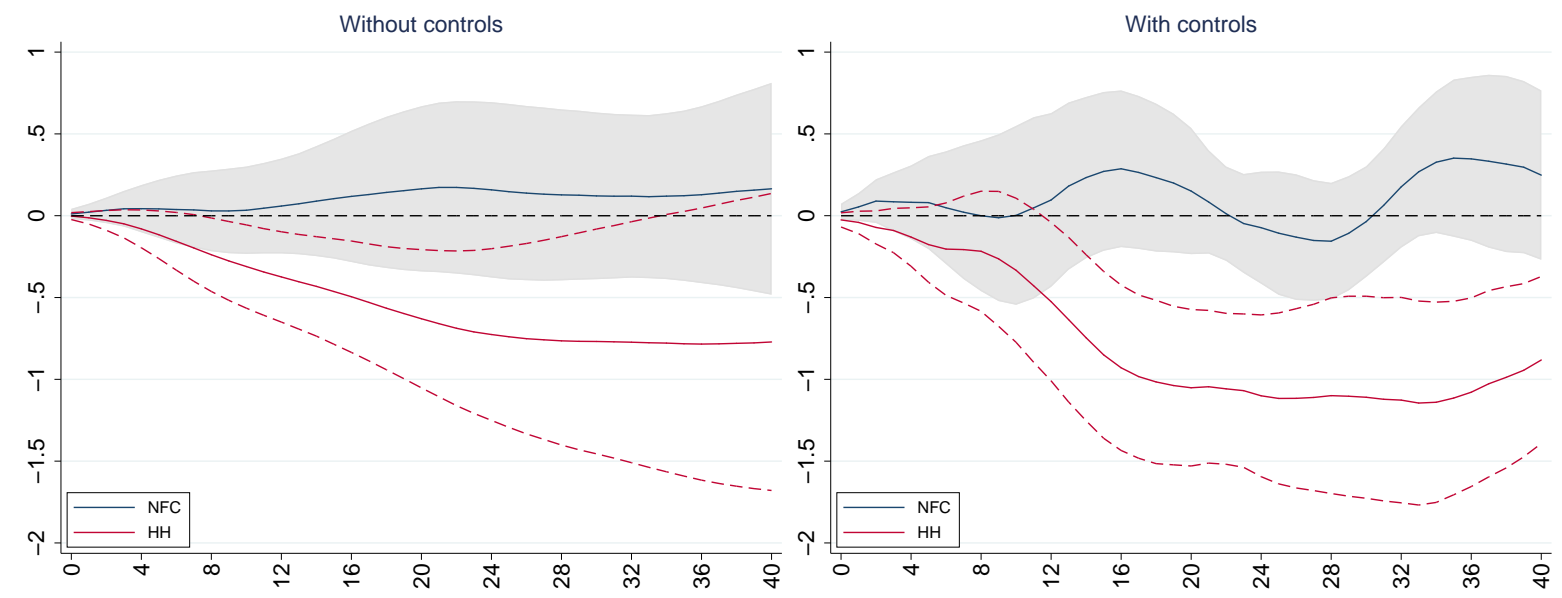

Notes: Cumulative impulse responses to a 1 p.p. increase in debt build-ups in the household and NFC sectors up to 20 quarters ahead. The grey area and dashed red lines refer to the $90 \%$ confidence bands.

Figure D.4: Impulse responses of investment spending: leverage groups
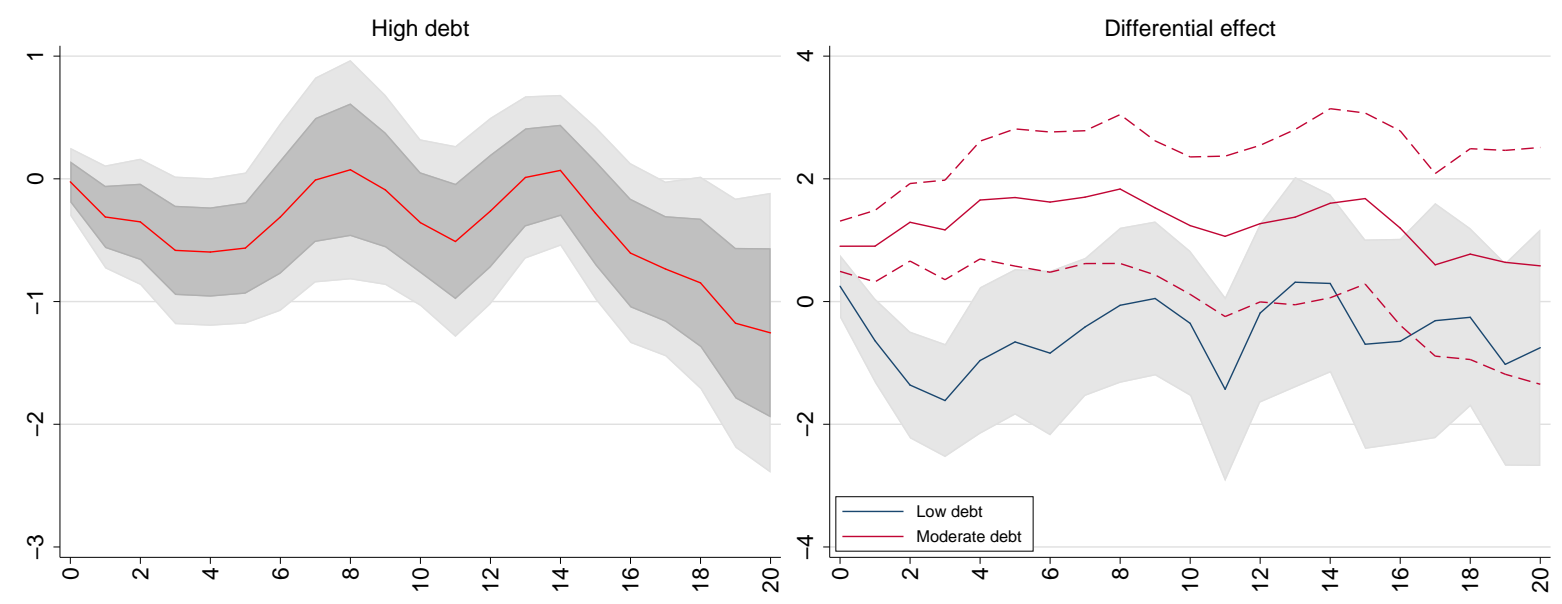

Notes: The left panel shows the cumulative impulse responses of capex for firms with high debt to a 10 p.p. increase in corporate debt build-ups up to 20 quarters ahead. The right panel shows the differences in point estimates, and associated $90 \%$ confidence bands, between the latter group and firms with a low/moderate debt (blue/red lines). 
Figure D.5: Impulse responses of investment spending: liquidity groups
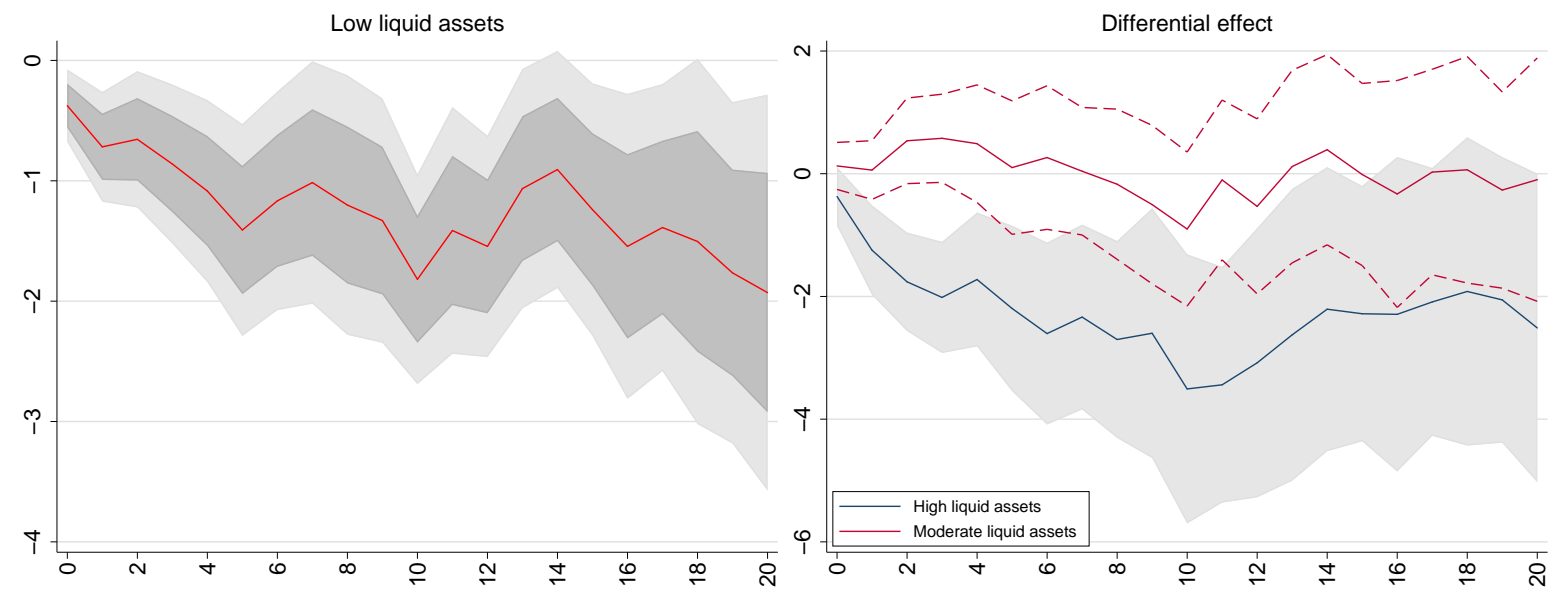

Notes: The left panel shows the cumulative impulse responses of capex for firms with low liquid assets to a 10 p.p. increase in corporate debt build-ups up to 20 quarters ahead. The right panel shows the differences in point estimates, and associated $90 \%$ confidence bands, between the latter group and firms with high/moderate liquidity (blue/red lines).

Figure D.6: Impulse responses of investment spending: debt-to-liquid assets
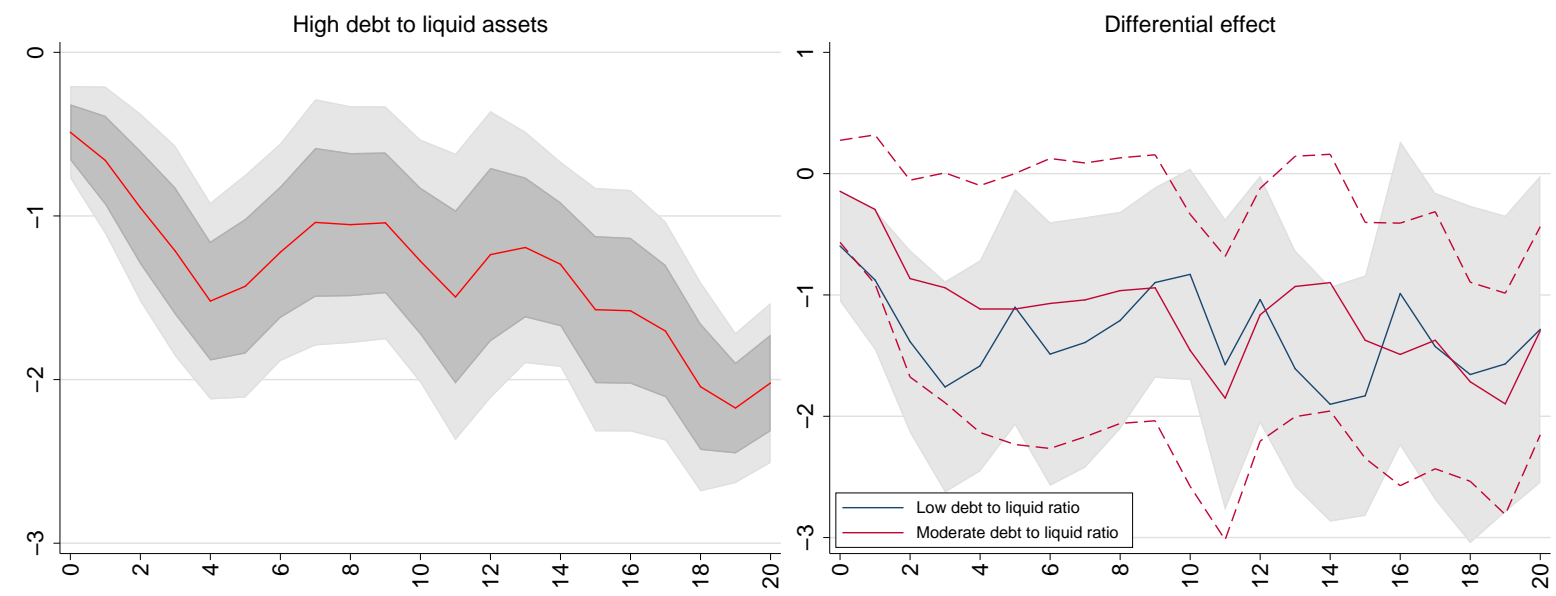

Notes: The left panel shows the cumulative impulse responses of capex for firms with high debt and low liquid assets to a 10 p.p. increase in corporate debt build-ups up to 20 quarters ahead. The dark (light) grey area refers to the 68 (90)\% confidence bands. The right panel shows the differences in point estimates, and associated $90 \%$ confidence bands, between the latter grouping and firms with a low/moderate debt-to-liquid asset ratio (blue/red lines).

Figure D.7: Impulse responses of corporate bond yields: vulnerable firms
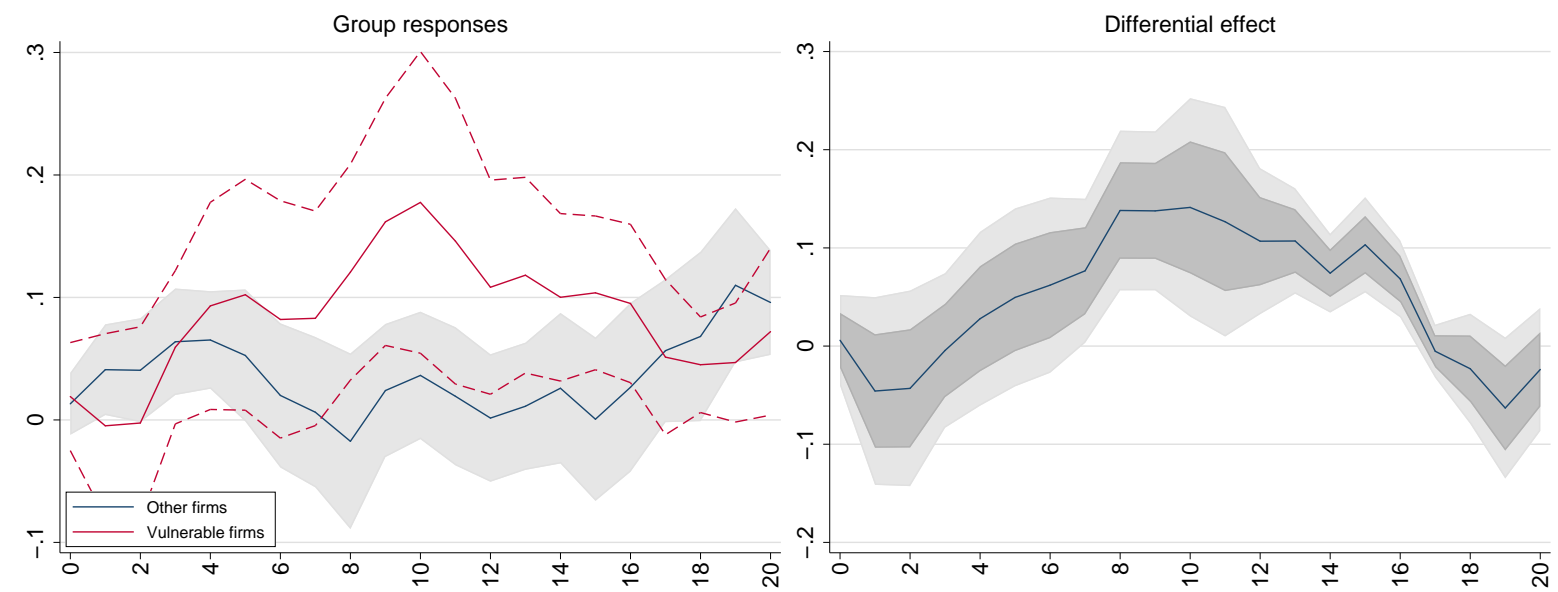

Notes: Cumulative impulse responses of corporate bond yields to a 10 p.p. increase in debt build-ups up to 20 quarters ahead. The right panel shows the difference between vulnerable and other firms. The dark (light) grey area refers to the $68 \%$ and $90 \%$ confidence bands. 
Table D.1: Descriptive statistics for vulnerable firms vs resilient firms (median values)

\begin{tabular}{lccccc}
\hline \hline & Size & Leverage & Liquidity & $\Delta \log ($ capex $)$ & ICR \\
\hline Vulnerable firms & 1508.10 & 0.37 & -0.01 & 3.58 & 2.85 \\
Resilient firms & 67.25 & 0.03 & 0.51 & 10.70 & 25.29 \\
Other firms & 320.13 & 0.24 & 0.18 & 6.02 & 4.03 \\
\hline \hline
\end{tabular}

Notes: Size refers to total real assets in 2009 USD, leverage to the ratio of short-term and long-term debt to total assets, liquidity to the ratio of net current assets to total assets, capex to capital spending, and ICR to the ratio of EBIT to interest expenses.

Figure D.8: Corporate debt build-ups for vulnerable firms vs resilient firms

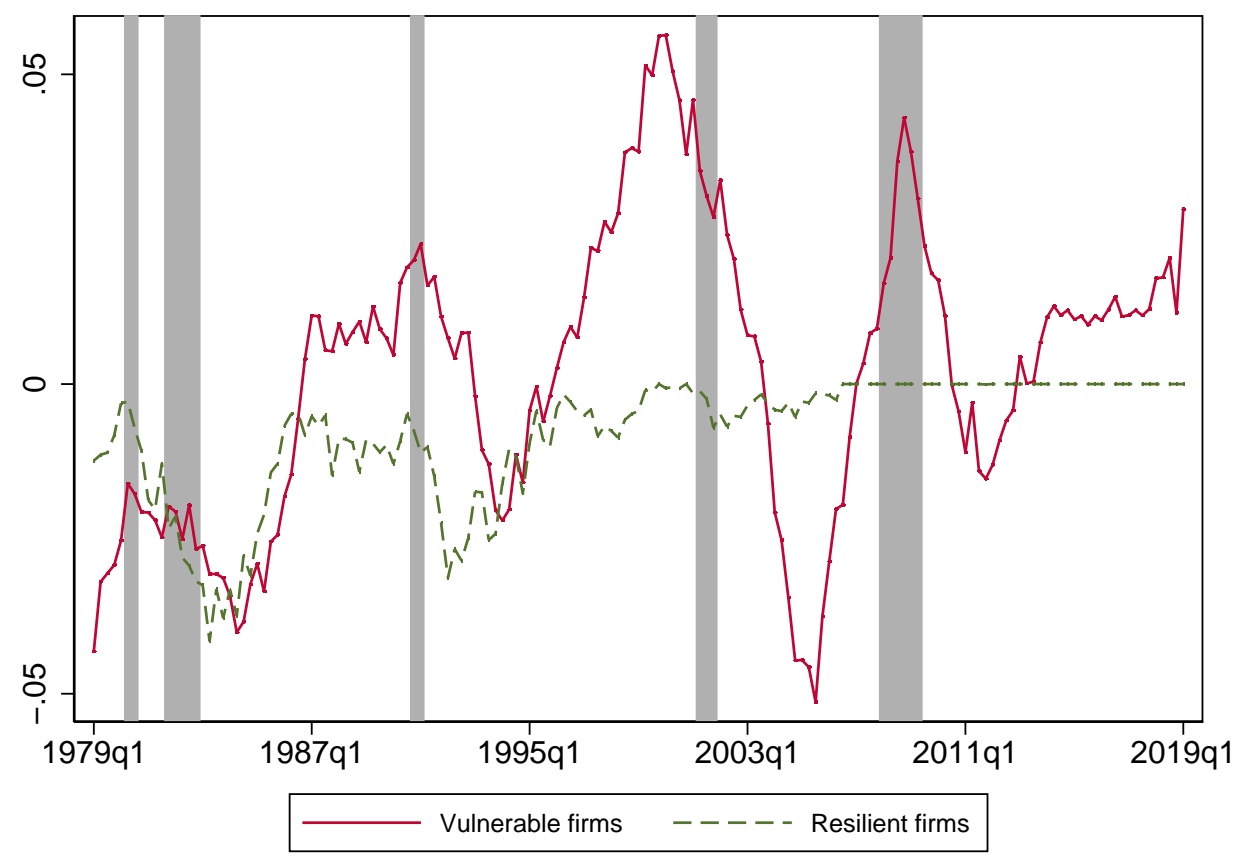

Sources: Compustat, and author's calculations.

Notes: Vulnerable (resilient) firms refer to firms that, at each point in time, belong simultaneously to the top (bottom) tertile of the leverage ratio and to the bottom (top) tertile of the liquid asset ratio. The shaded area indicates recessions as defined by the NBER.

Figure D.9: Financial constraints based on the HM index

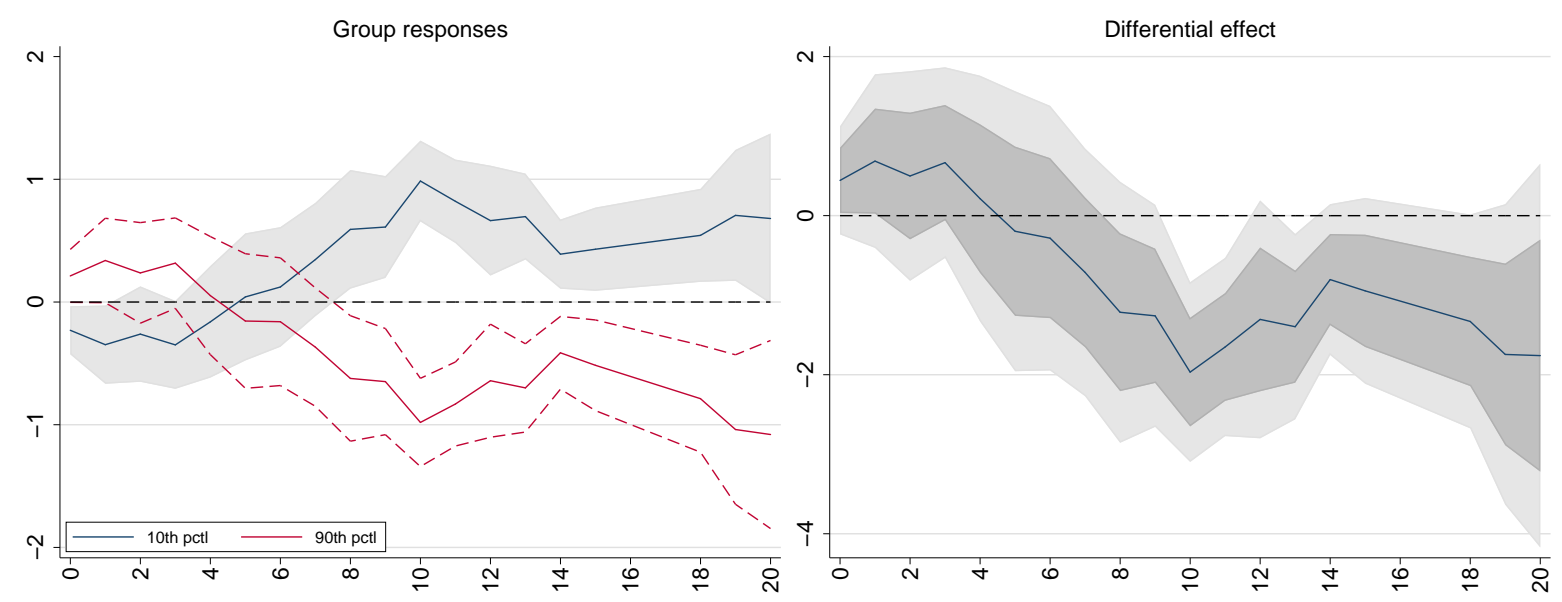

Notes: Cumulative impulse responses of capex to a 10 p.p. increase in corporate debt build-ups up to 20 quarters ahead. The grey area (red lines) refer to the mean response of the $10^{t h}\left(90^{t h}\right)$ percentile of the Hoberg and Maksimovic (2015)'s index and associated $90 \%$ confidence bands. The right panel depicts the difference, and associated $68 \%$ and $90 \%$ confidence bands, between the two impulse responses. 
Figure D.10: Financial constraints based on firm age: young firms $<=10$ years

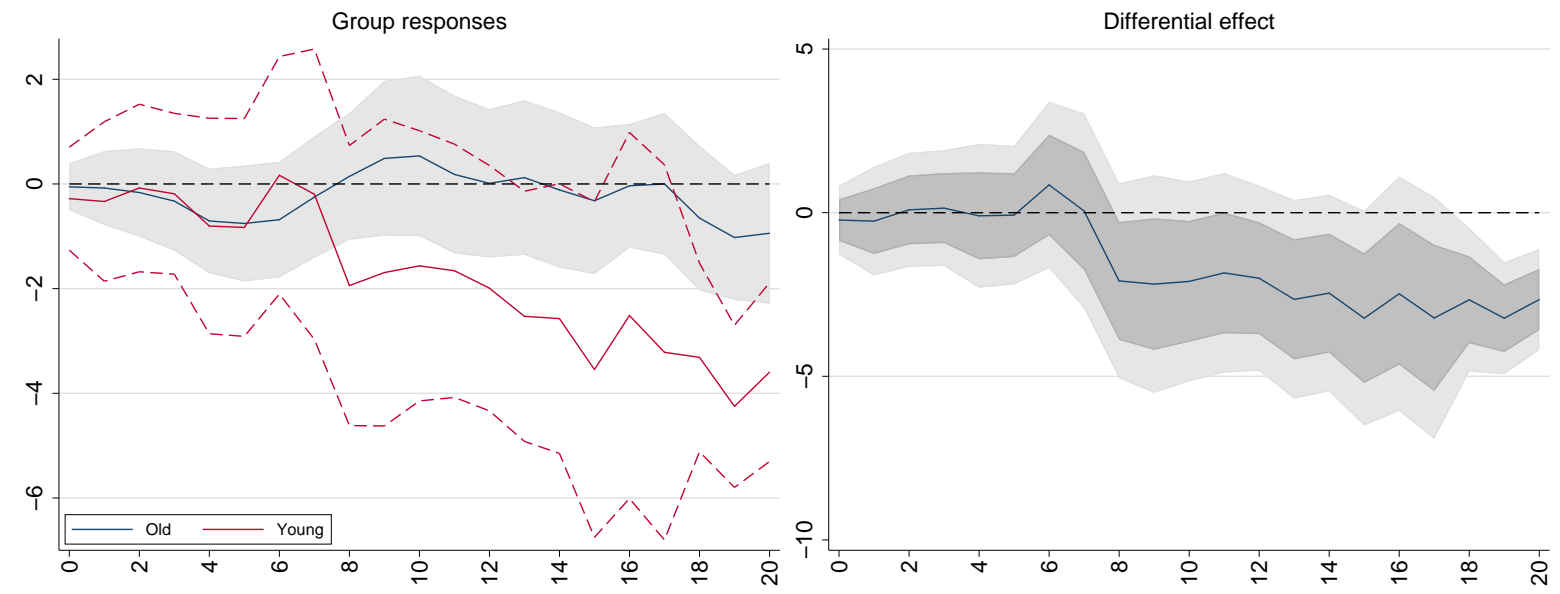

Notes: Cumulative impulse responses of capex to a 10 p.p. increase in corporate debt build-ups up to 20 quarters ahead. The grey area and red lines refer to the response of old and young firms and associated $90 \%$ confidence bands. Young firms are defined as firms that are less or equal than ten years old, and old firms above ten years old. The right panel depicts the difference, and associated $68 \%$ and $90 \%$ confidence bands, between the impulse responses of the young firms and old firms.

Figure D.11: Financial constraints based on firm age: young firms $<=15$ years
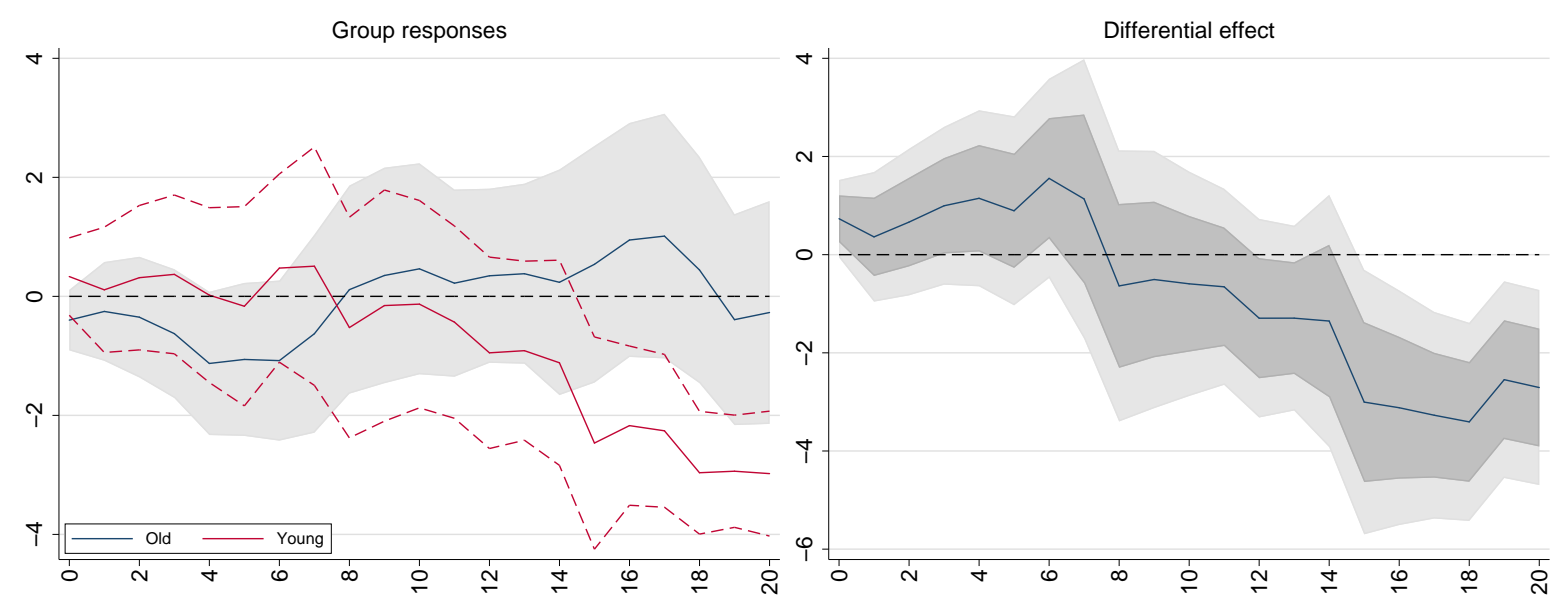

Notes: Cumulative impulse responses of capex to a 10 p.p. increase in corporate debt build-ups up to 20 quarters ahead. The grey area and red lines refer to the response of old and young firms and associated $90 \%$ confidence bands. Young firms are defined as firms that are less or equal than 15 years old, and old firms above 15 years old. The right panel depicts the difference, and associated $68 \%$ and $90 \%$ confidence bands, between the impulse responses of the young firms and old firms. 
Figure D.12: Financial constraints based on firm size
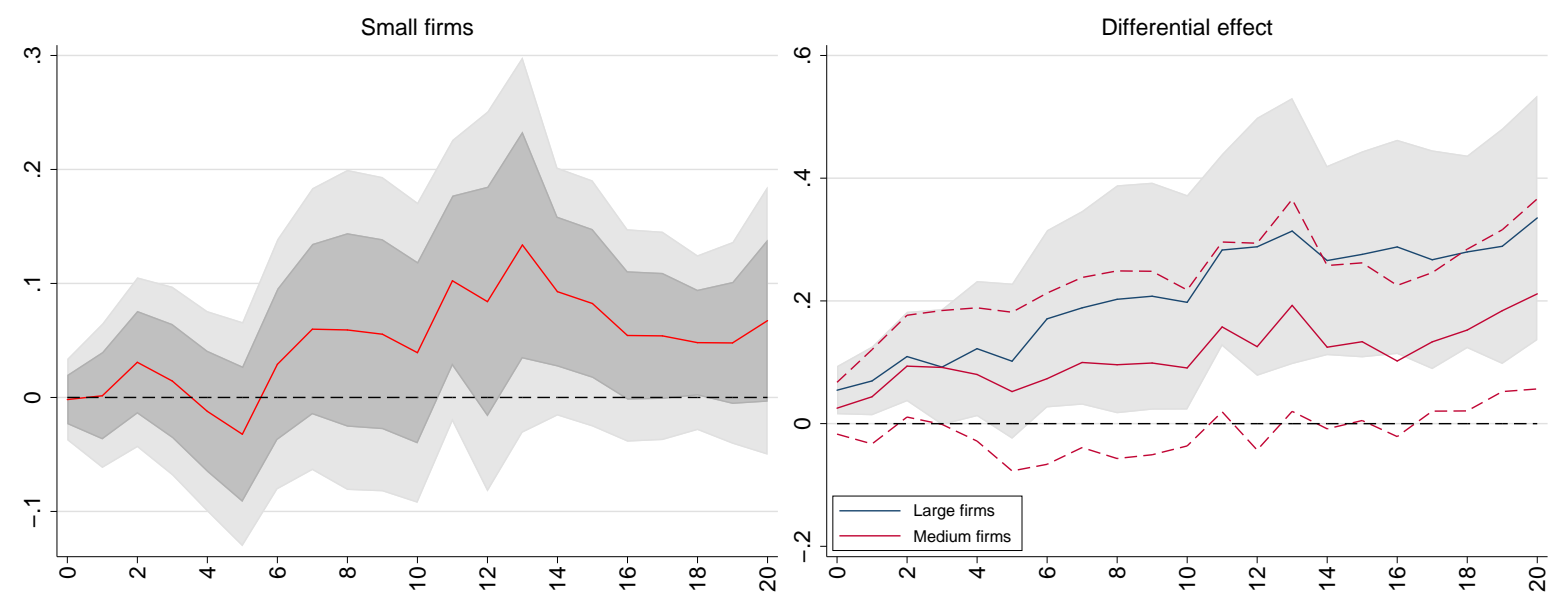

Notes: The left panel shows the cumulative impulse responses of capex for small firms to a 10 p.p. increase in corporate debt build-ups up to 20 quarters ahead. The right panel shows the differences in point estimates, and associated $90 \%$ confidence bands, between small firms and large/medium-sized firms (blue/red lines).

Figure D.13: Impulse responses of intangible investment from Ewens et al. (2019)

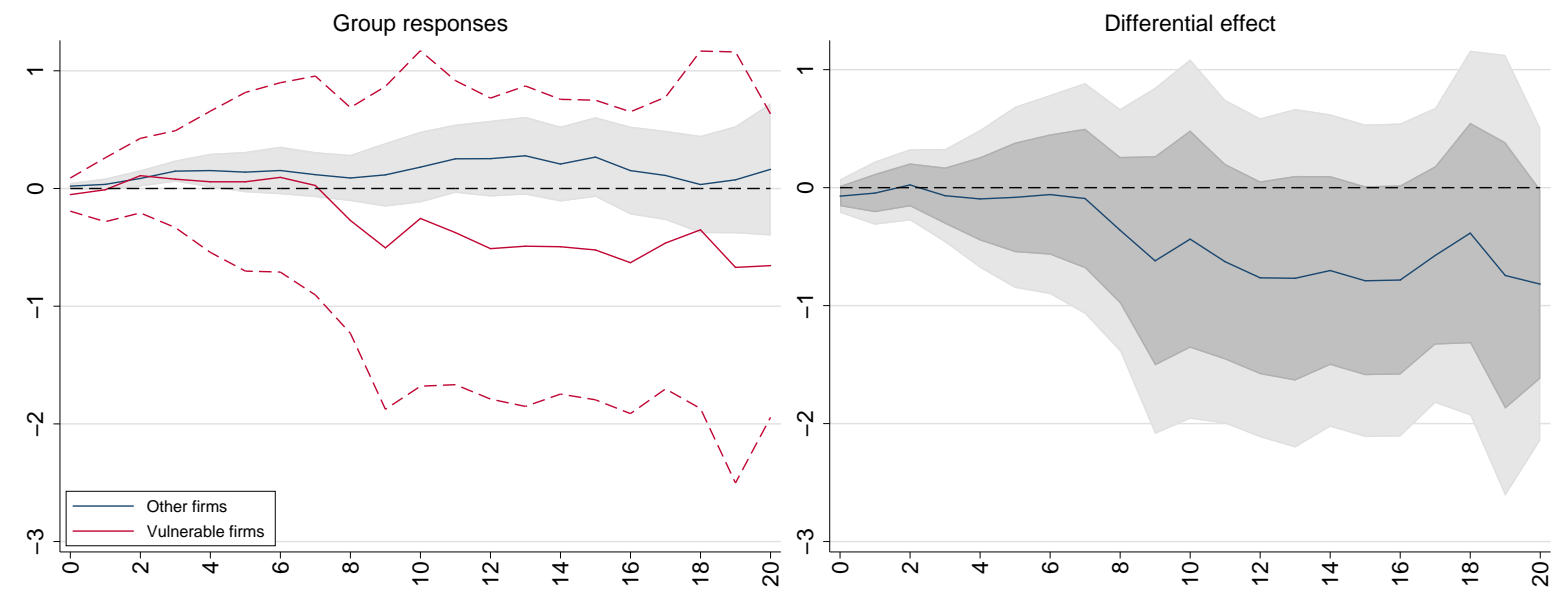

Notes: Cumulative impulse responses of the intangible capital-to-asset ratio from Ewens et al. (2019) to a 10 p.p. increase in corporate debt build-ups up to 20 quarters ahead. The red lines refer to the response of vulnerable firms and associated $90 \%$ confidence bands. The blue line and grey area refer to the response and $90 \%$ confidence bands for other firms. The right panel depicts the difference, and associated $68 \%$ and $90 \%$ confidence bands, between the responses of vulnerable firms and all other firms.

Figure D.14: Impulse responses with investment rate as the dependent variable

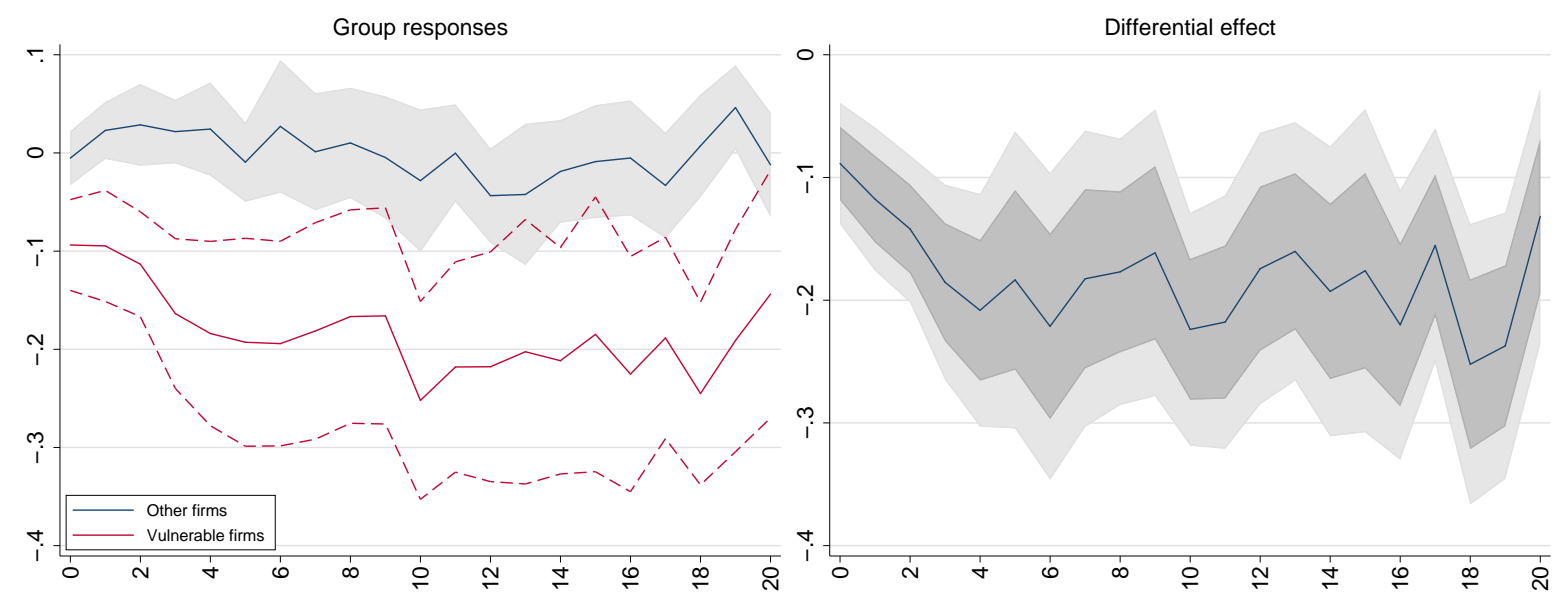

Notes: Cumulative impulse responses of the investment rate to a 10 p.p. increase in corporate debt build-ups up to 20 quarters ahead. The red lines (blue line and grey area) refer to the response of vulnerable (other) firms and associated $90 \%$ confidence bands. The right panel depicts the difference, with the $68 \%$ and $90 \%$ confidence bands, between vulnerable and other firms. 
Figure D.15: Impulse responses with additional firm controls
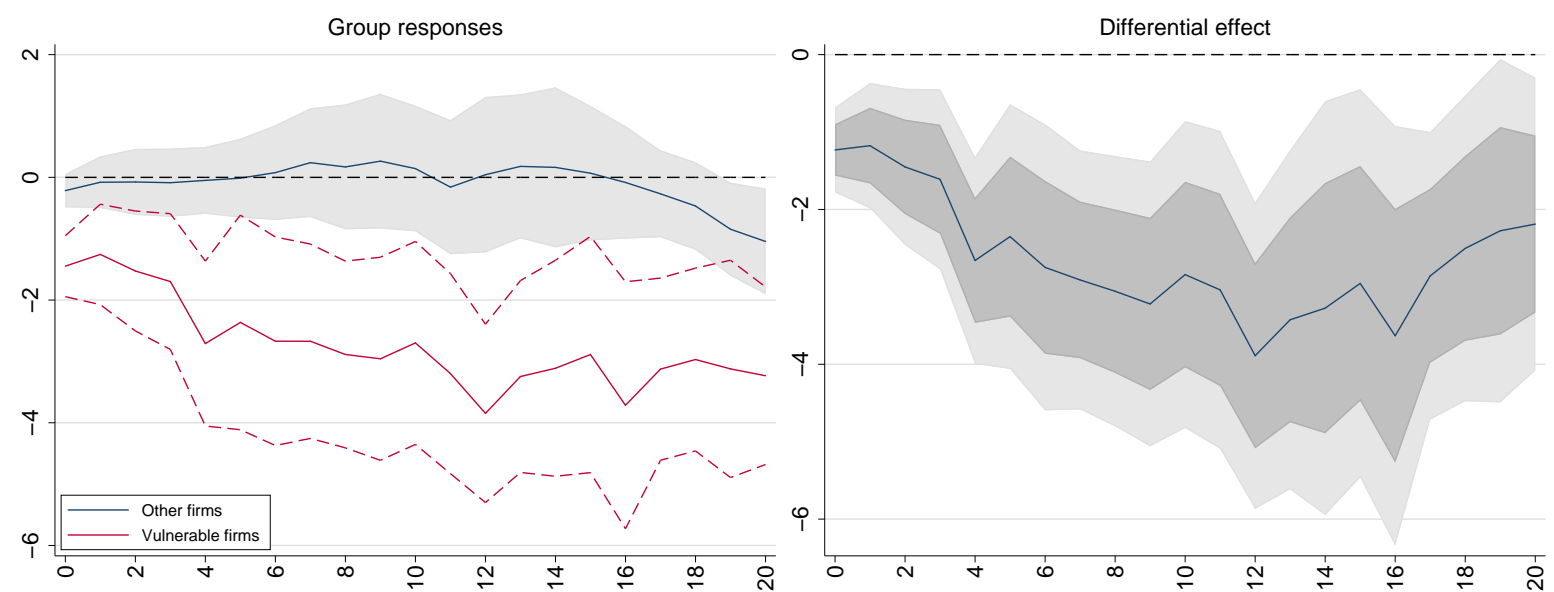

Notes: Cumulative impulse responses of capex to a 10 p.p. increase in corporate debt build-ups up to 20 quarters ahead. The red lines (blue line and grey area) refer to the response of vulnerable (other) firms and associated $90 \%$ confidence bands. The right panel depicts the difference, with the $68 \%$ and $90 \%$ confidence bands, between vulnerable and other firms.

Figure D.16: Impulse responses to debt booms in the net debt-to-asset ratio

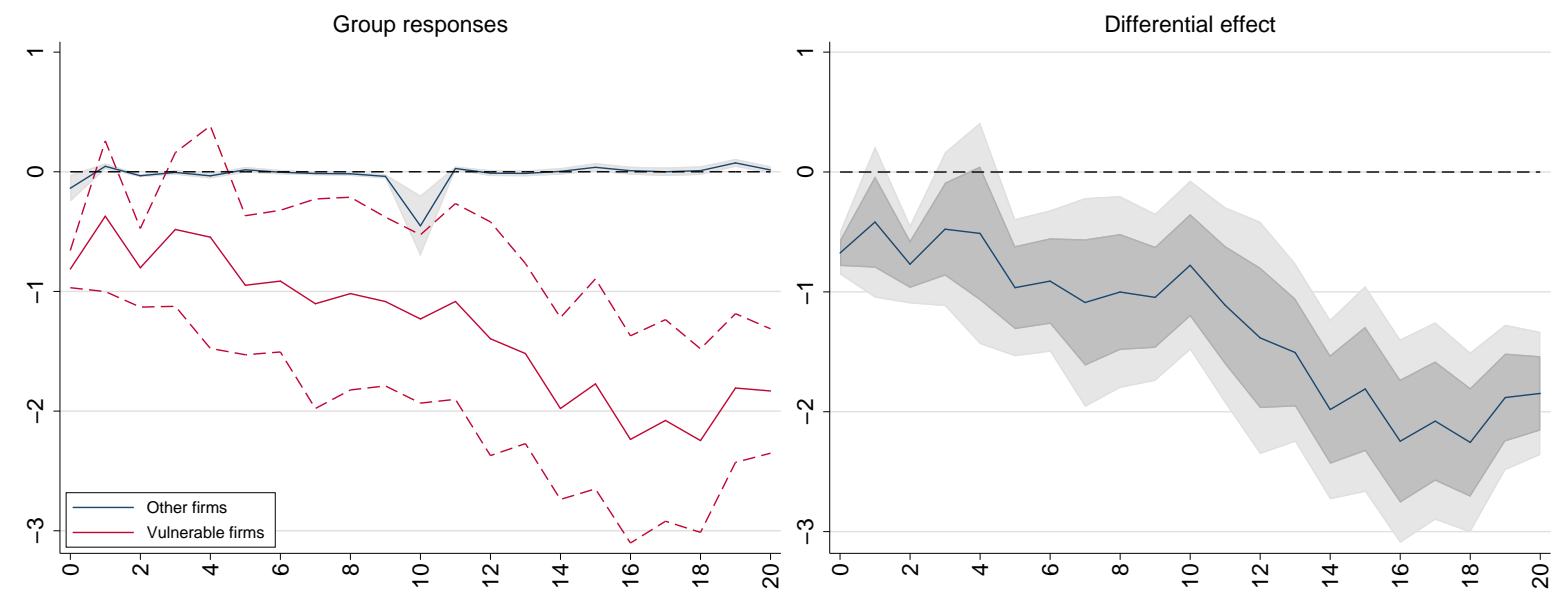

Notes: Cumulative impulse responses of capex to a 10 p.p. increase in corporate debt build-ups up to 20 quarters ahead. The red lines (blue line and grey area) refer to the response of vulnerable (other) firms and associated $90 \%$ confidence bands. The right panel depicts the difference, with the $68 \%$ and $90 \%$ confidence bands, between vulnerable and other firms.

Figure D.17: Impulse responses to debt booms over the past five years

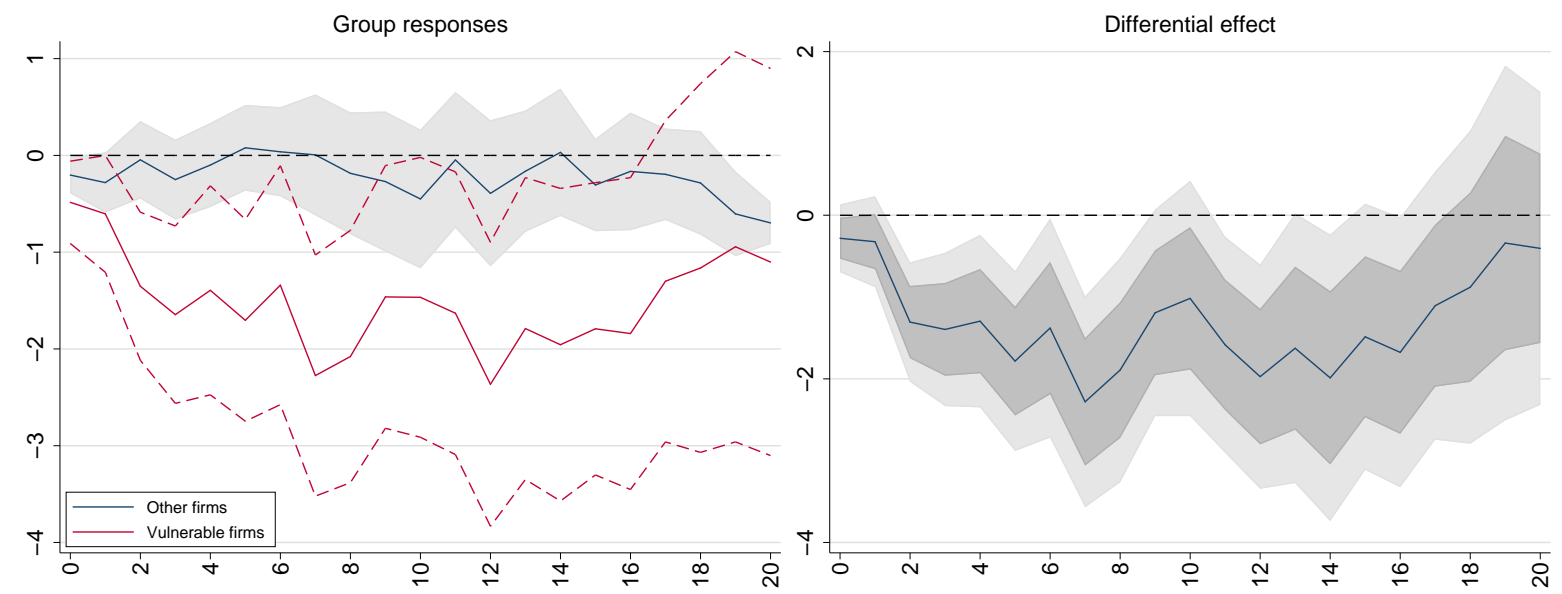

Notes: Cumulative impulse responses of capex to a 10 p.p. increase in corporate debt build-ups up to 20 quarters ahead. The red lines (blue line and grey area) refer to the response of vulnerable (other) firms and associated $90 \%$ confidence bands. The right panel depicts the difference, with the $68 \%$ and $90 \%$ confidence bands, between vulnerable and other firms. 
Figure D.18: Impulse responses with gross current assets as the proxy for liquid assets

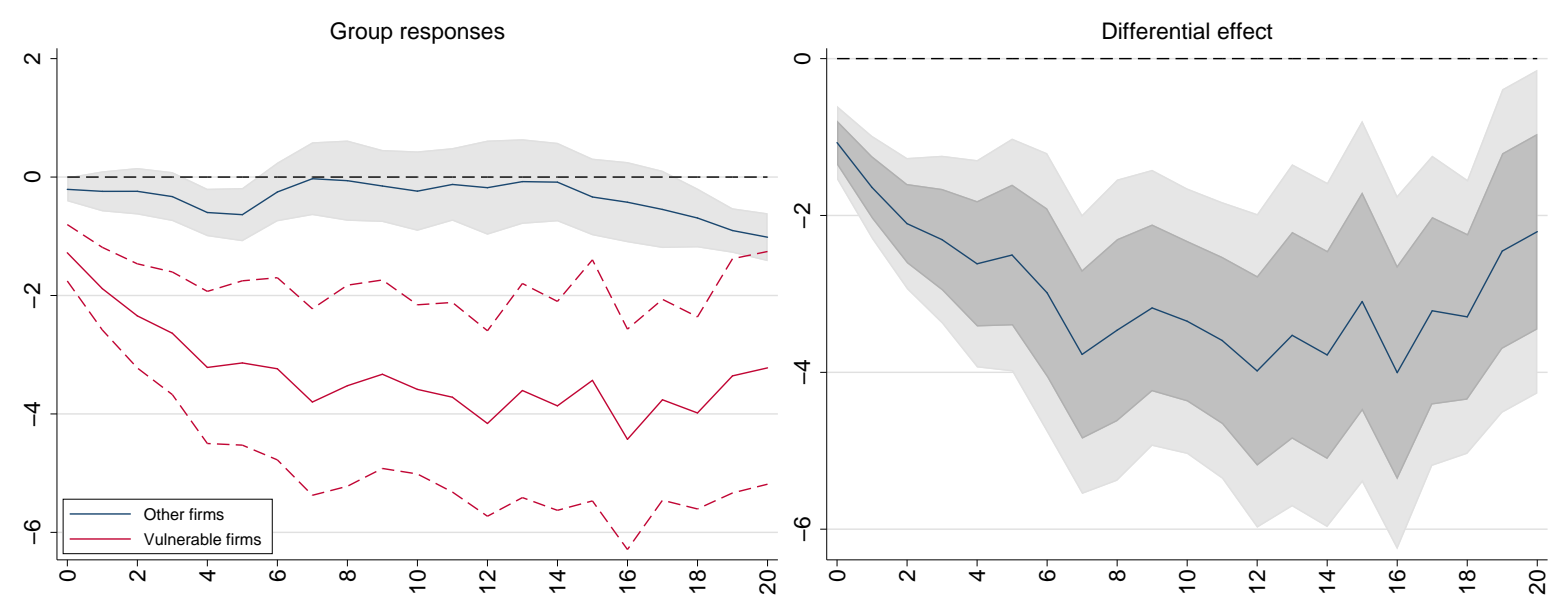

Notes: Cumulative impulse responses of capex to a 10 p.p. increase in corporate debt build-ups up to 20 quarters ahead. The red lines (blue line and grey area) refer to the response of vulnerable (other) firms and associated $90 \%$ confidence bands. The right panel depicts the difference, with the $68 \%$ and $90 \%$ confidence bands, between vulnerable and other firms.

Figure D.19: Impulse responses of vulnerable firms with cash as the proxy for liquid assets
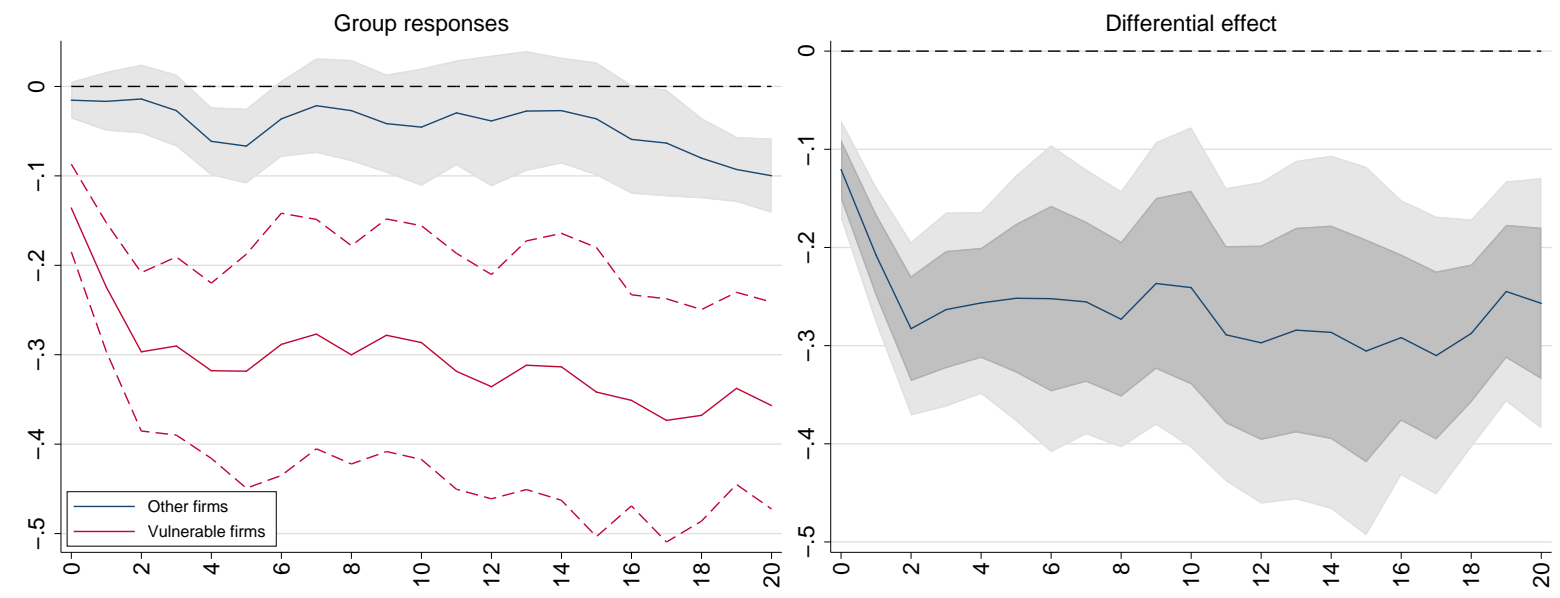

Notes: Cumulative impulse responses of capex to a 10 p.p. increase in corporate debt build-ups up to 20 quarters ahead. The red lines (blue line and grey area) refer to the response of vulnerable (other) firms and associated $90 \%$ confidence bands. The right panel depicts the difference, with the $68 \%$ and $90 \%$ confidence bands, between vulnerable and other firms.

Figure D.20: Impulse responses of vulnerable firms: restrict to ICR $<2$

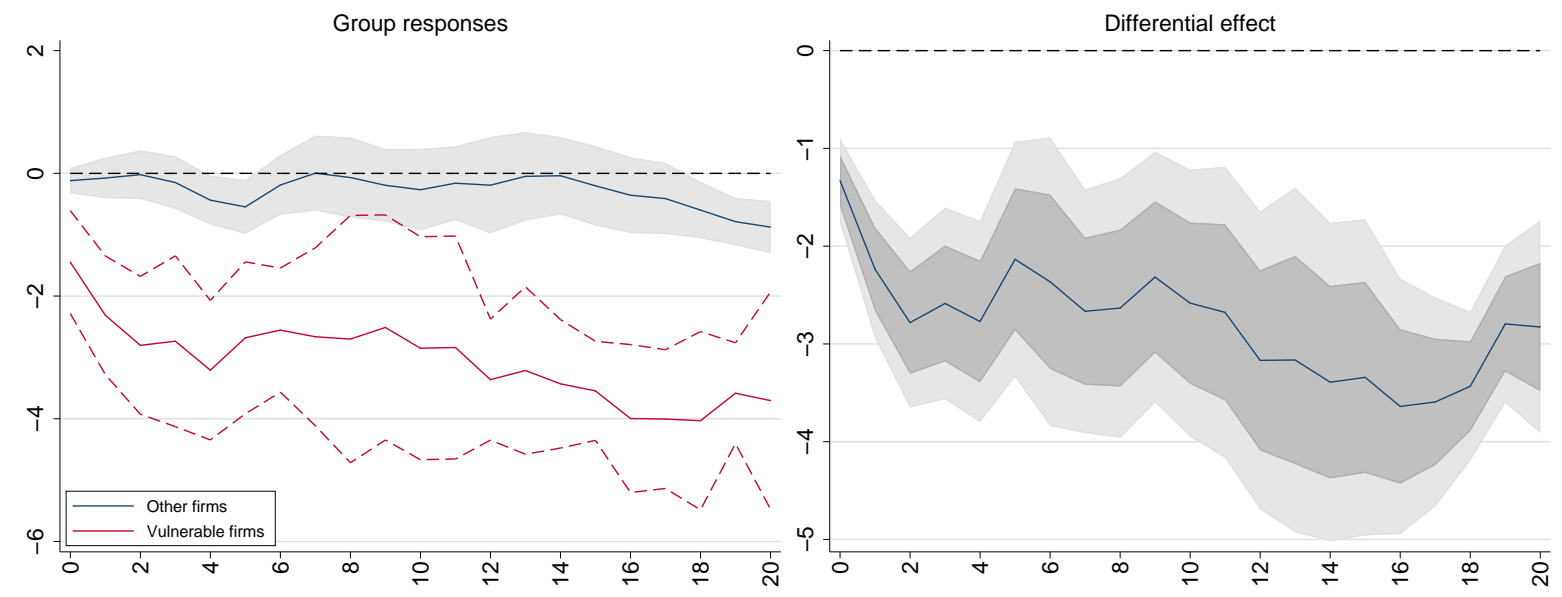

Notes: Cumulative impulse responses of capex to a 10 p.p. increase in corporate debt build-ups up to 20 quarters ahead. The red lines (blue line and grey area) refer to the response of vulnerable (other) firms and associated $90 \%$ confidence bands. The right panel depicts the difference, with the $68 \%$ and $90 \%$ confidence bands, between vulnerable and other firms. 
Figure D.21: Impulse responses with industry-specific shocks
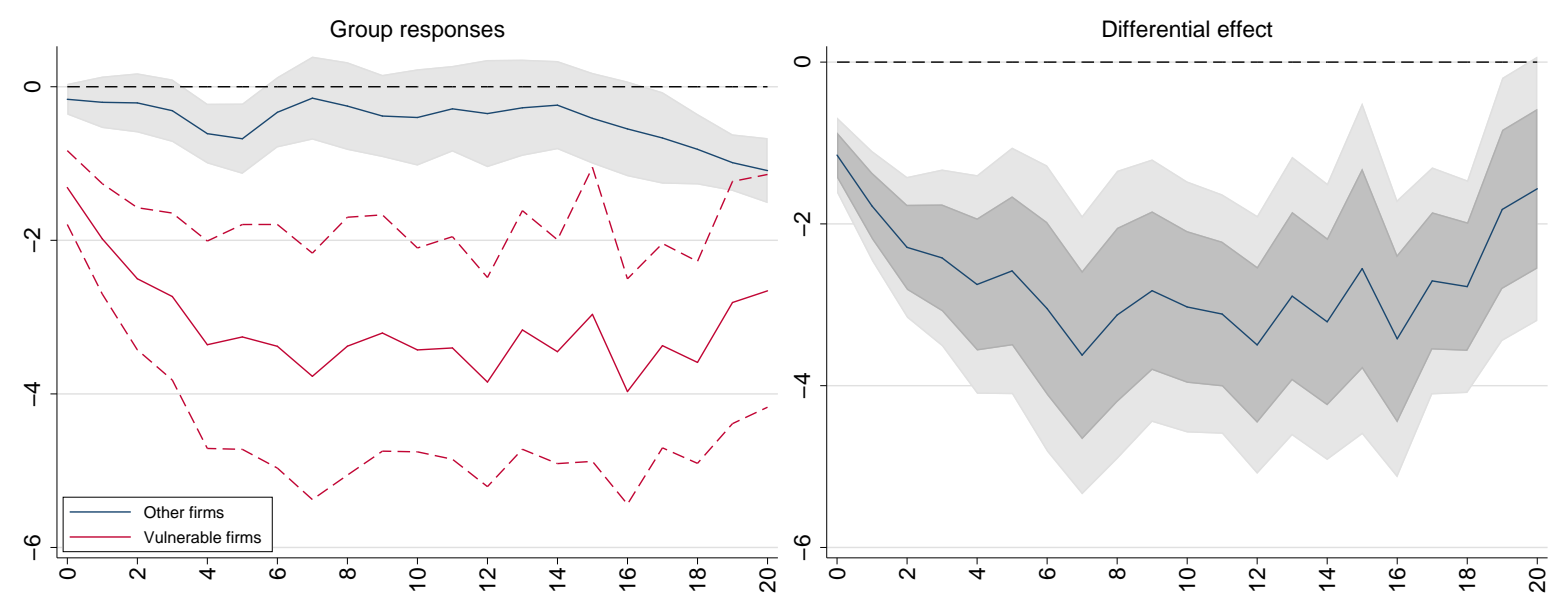

Notes: Cumulative impulse responses of capex to a 10 p.p. increase in corporate debt build-ups up to 20 quarters ahead. The red lines (blue line and grey area) refer to the response of vulnerable (other) firms and associated $90 \%$ confidence bands. The right panel depicts the difference, with the $68 \%$ and $90 \%$ confidence bands, between vulnerable and other firms.

Figure D.22: Impulse responses of vulnerable firms: definition within each industry
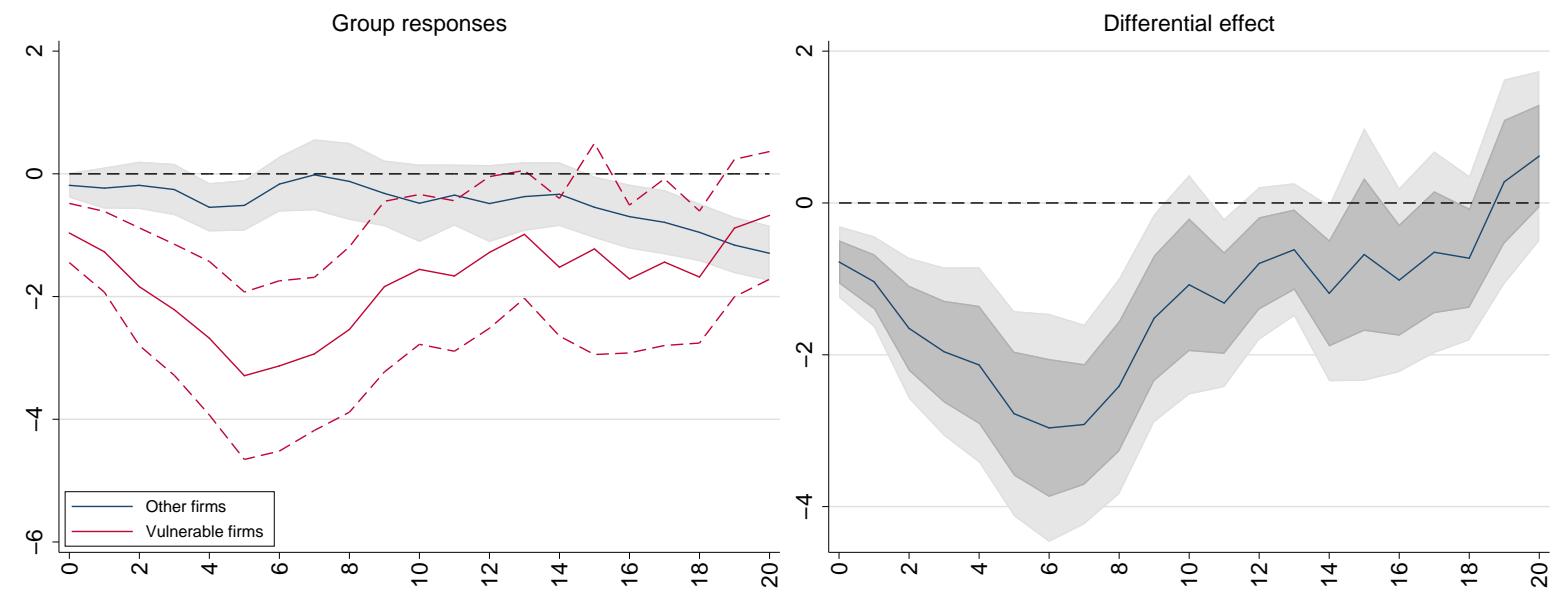

Notes: Cumulative impulse responses of capex to a 10 p.p. increase in corporate debt build-ups up to 20 quarters ahead. The red lines (blue line and grey area) refer to the response of vulnerable (other) firms and associated $90 \%$ confidence bands. The right panel depicts the difference, with the $68 \%$ and $90 \%$ confidence bands, between vulnerable and other firms.

Figure D.23: Impulse responses in the pre-GFC period

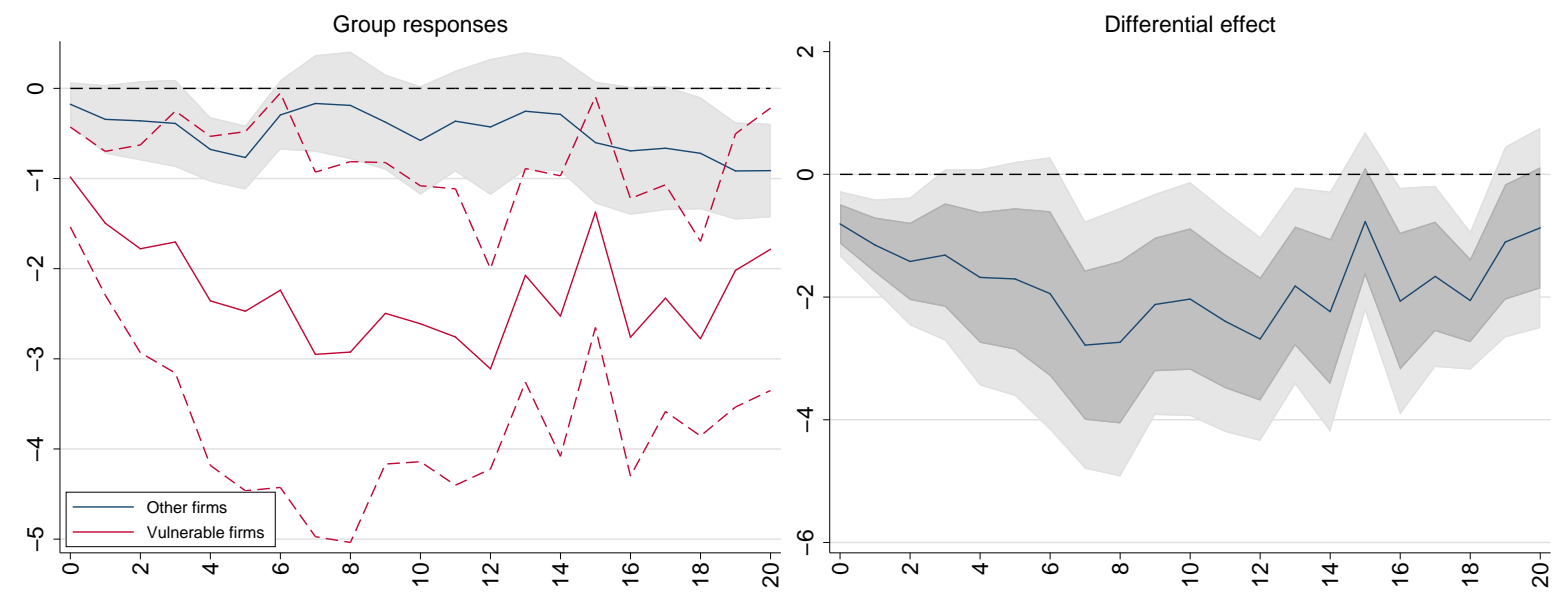

Notes: Cumulative impulse responses of capex to a 10 p.p. increase in corporate debt build-ups up to 20 quarters ahead. The red lines (blue line and grey area) refer to the response of vulnerable (other) firms and associated $90 \%$ confidence bands. The right panel depicts the difference, with the $68 \%$ and $90 \%$ confidence bands, between vulnerable and other firms. 
Figure D.24: Impulse responses in expansions and recessions

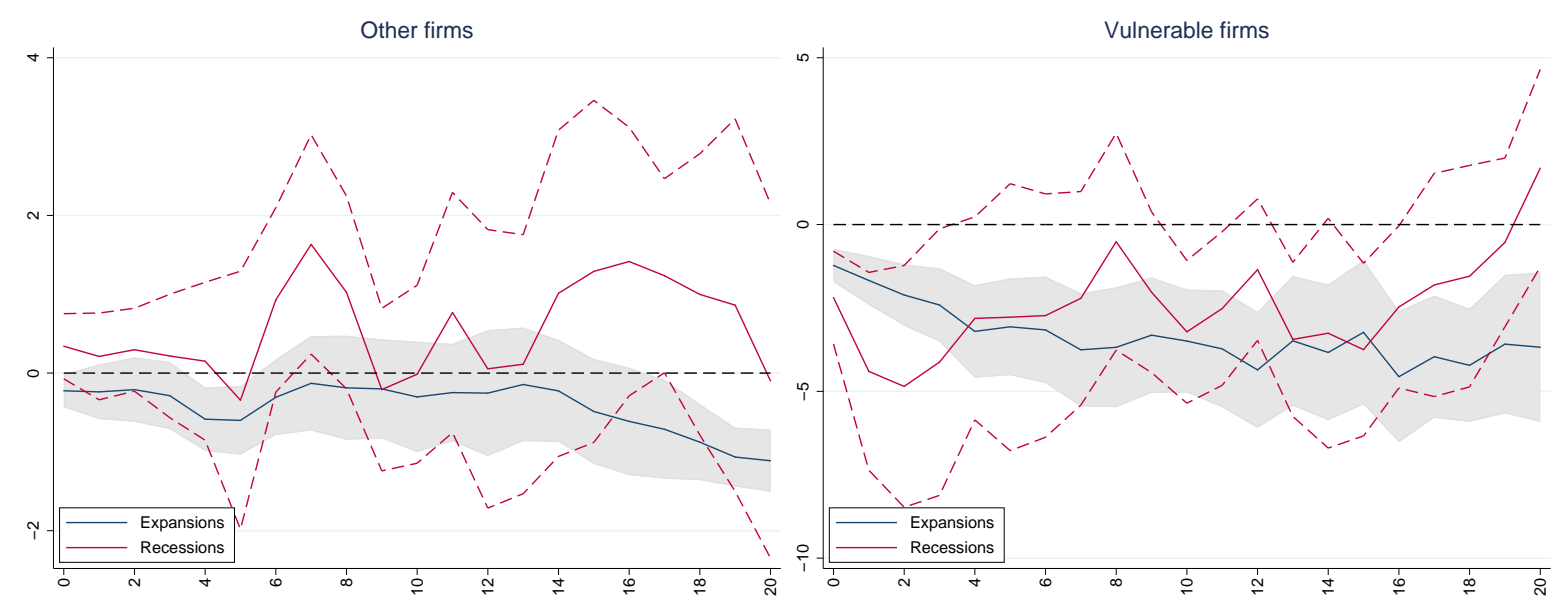

Notes: Cumulative impulse responses of capex to a 10 p.p. increase in corporate debt build-ups up to 20 quarters ahead. The dashed red lines and grey area refer to the $90 \%$ confidence bands for the response in recessions and expansions.

Figure D.25: Difference in impulse responses between vulnerable firms and other firms in expansions and recessions

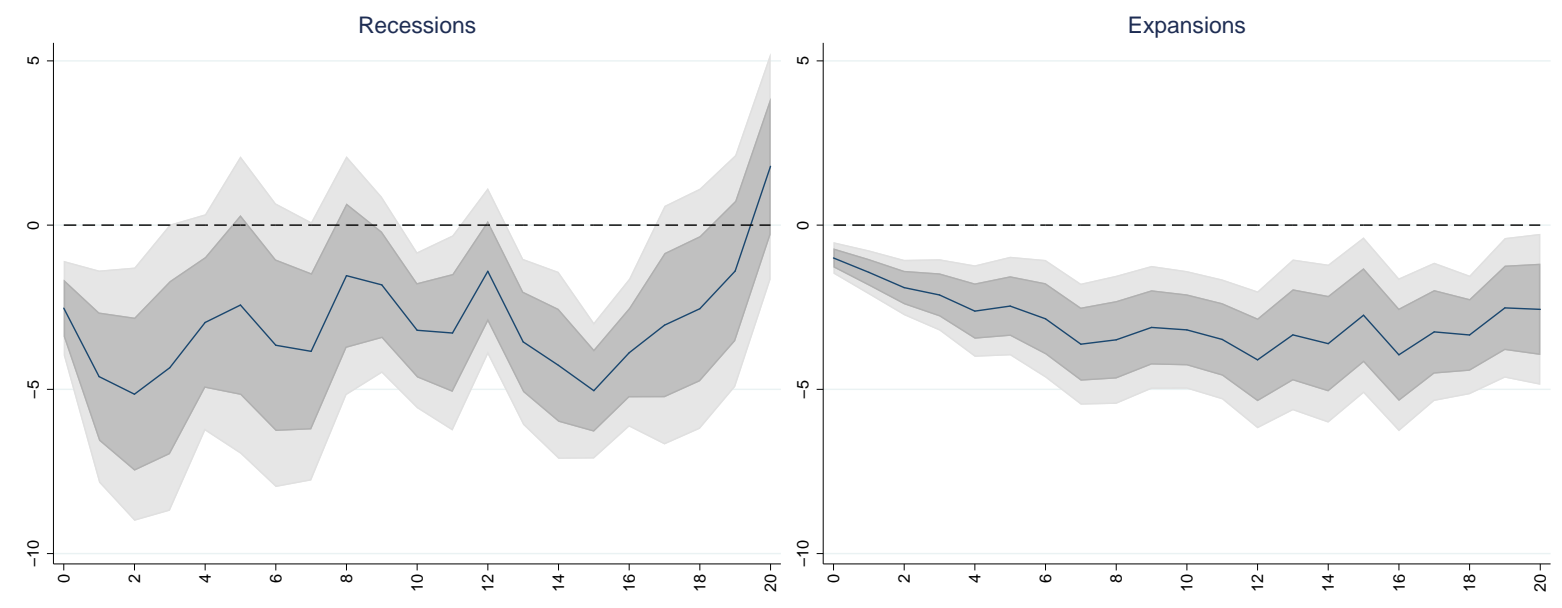

Notes: The figure shows the difference in cumulative impulse responses of capex between vulnerable firms and other firms to a 10 p.p. increase in corporate debt build-ups up to 20 quarters ahead in recessions (left panel) and expansions (right panel). The dark (light) grey area refers to the $68 \%$ and $90 \%$ confidence bands.

Figure D.26: Impulse responses during periods of major tightenings in credit conditions

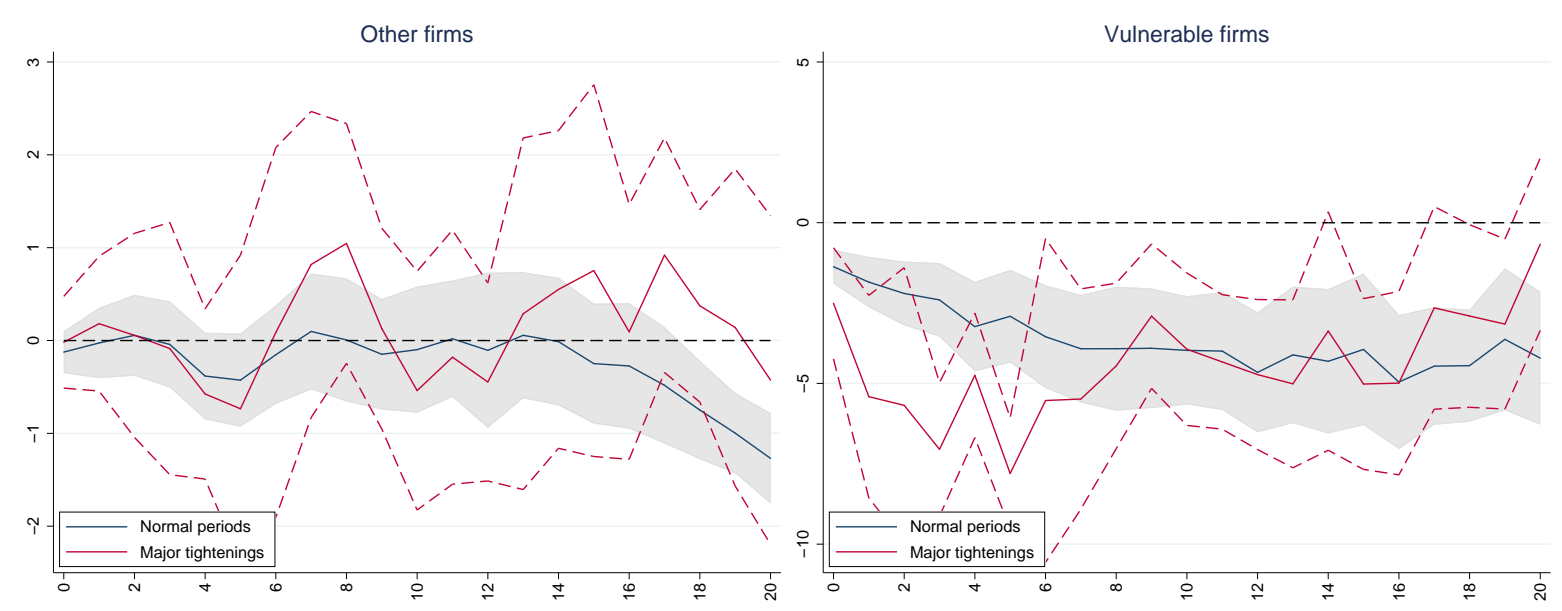

Notes: Cumulative impulse responses of capex to a 10 p.p. increase in corporate debt build-ups up to 20 quarters ahead. The dashed red lines and grey area refer to the $90 \%$ confidence bands for the response during periods of major tightenings in credit conditions and during normal periods. 
Figure D.27: Difference in impulse responses between vulnerable firms and other firms during periods of large tightenings in credit conditions

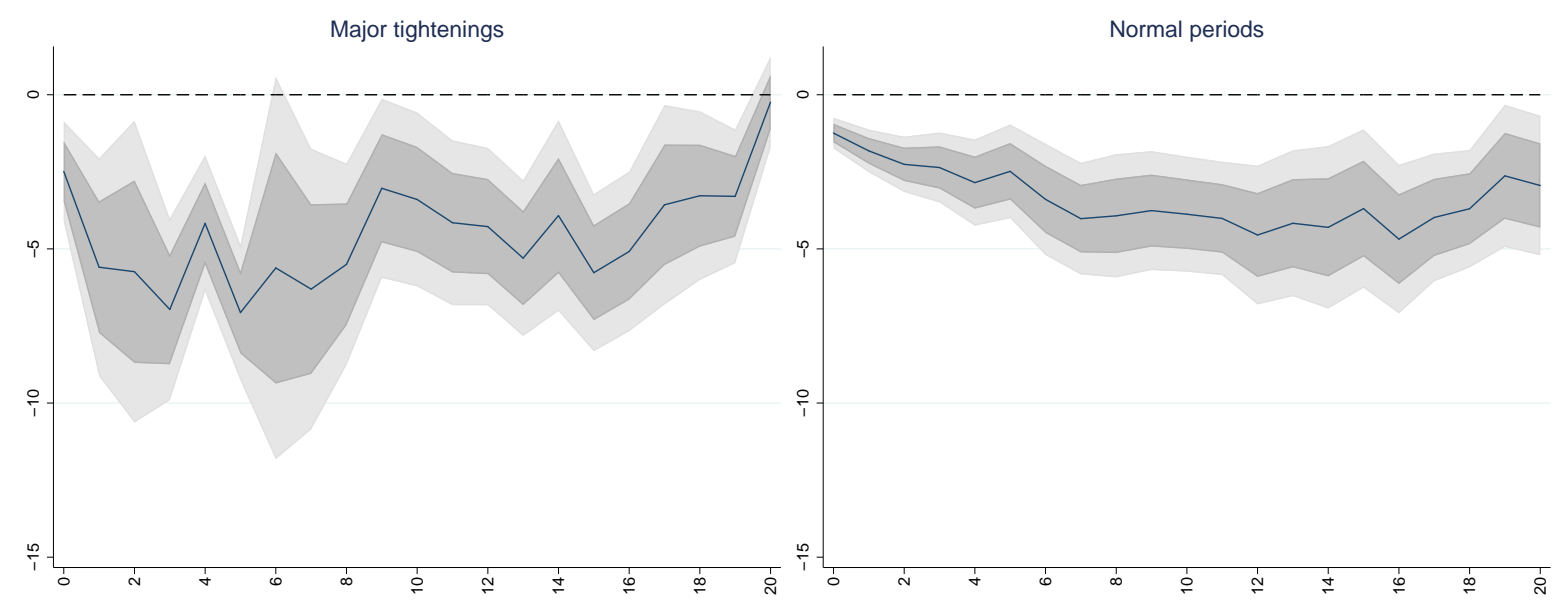

Notes: The figure shows the difference in cumulative impulse responses of capex between vulnerable firms and other firms to a 10 p.p. increase in corporate debt build-ups up to 20 quarters ahead during major tightening periods in credit conditions (left panel) and during normal times (right panel). The dark (light) grey area refers to the $68 \%$ and $90 \%$ confidence bands.

Figure D.28: Impulse responses with a one-lag model

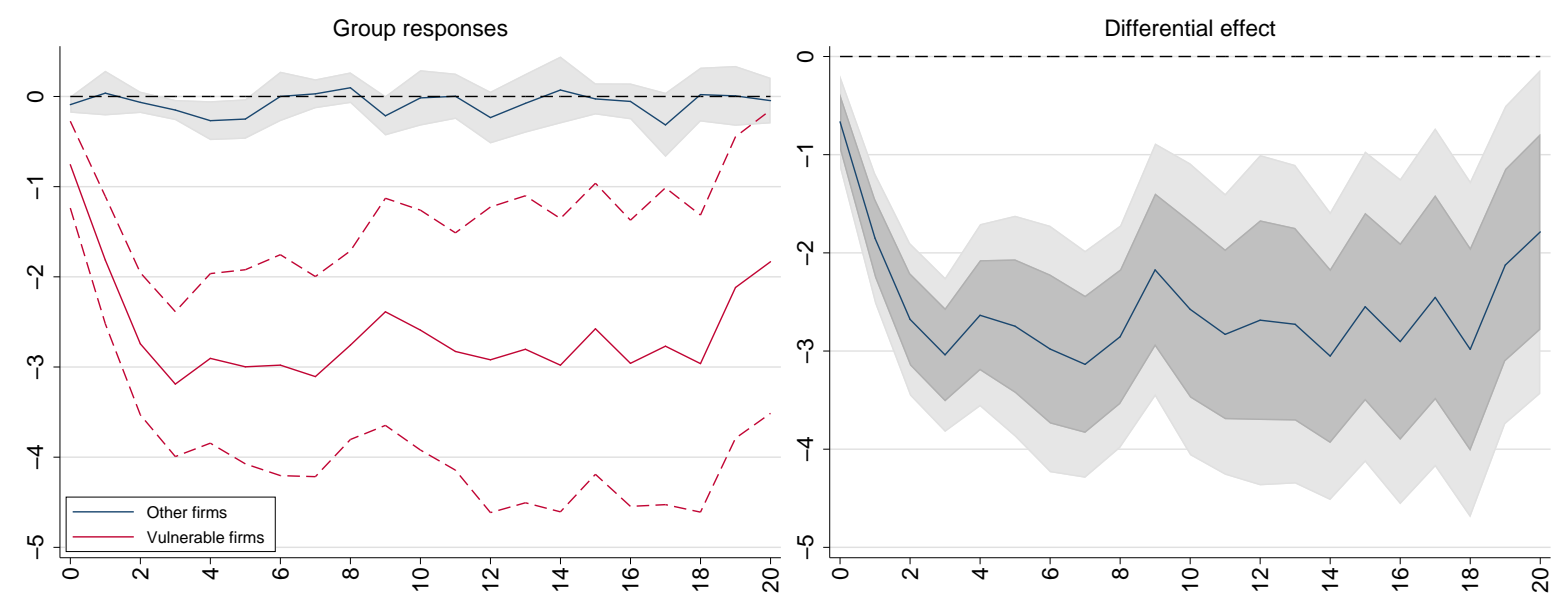

Notes: Cumulative impulse responses of capex to a 10 p.p. increase in corporate debt build-ups up to 20 quarters ahead. The red lines (blue line and grey area) refer to the response of vulnerable (other) firms and associated $90 \%$ confidence bands. The right panel depicts the difference, with the $68 \%$ and $90 \%$ confidence bands, between vulnerable and other firms. 


\section{References}

Almeida, H., Campello, M. and Weisbach, M. S. (2004), 'The cash flow sensitivity of cash', The Journal of Finance 59(4), 1777-1804.

Bacchetta, P., Benhima, K. and Poilly, C. (2019), 'Corporate Cash and Employment', American Economic Journal: Macroeconomics 11(3), 30-66.

Barth, M. J. and Ramey, V. A. (2002), The Cost Channel of Monetary Transmission, in 'NBER Macroeconomics Annual 2001, Volume 16', NBER Chapters, National Bureau of Economic Research, Inc, pp. 199-256.

Bates, T. W., Kahle, K. M. and Stulz, R. M. (2009), 'Why Do U.S. Firms Hold So Much More Cash than They Used To?', The Journal of Finance 64(5), 1985-2021.

Blickle, K. S. and Santos, J. A. C. (2020), The Costs of Corporate Debt Overhang, Available at https://ssrn.com/abstract $=3708502$, SSRN.

Brunnermeier, M. and Krishnamurthy, A. (2020), 'Corporate Debt Overhang and Credit Policy', Brookings Papers on Economic Activity (forthcoming).

Buera, F. and Karmakar, S. (2019), Real effects of financial distress: the role of heterogeneity, Bank of England working papers 814, Bank of England.

Campello, M., Graham, J. R. and Harvey, C. R. (2010), 'The real effects of financial constraints: Evidence from a financial crisis', Journal of Financial Economics 97(3), 470-487.

Cunha, I. and Pollet, J. (2020), 'Why Do Firms Hold Cash? Evidence from Demographic Demand Shifts', Review of Financial Studies 33(9), 4102-4138.

Dedola, L. and Lippi, F. (2005), 'The monetary transmission mechanism: Evidence from the industries of five OECD countries', European Economic Review 49(6), 1543-1569.

Dell'Ariccia, G., Igan, D., Laeven, L. and Tong, H. (2016), 'Credit booms and macrofinancial stability', Economic Policy 31(86), 299-355.

Durante, E., Ferrando, A. and Vermeulen, P. (2020), Monetary policy, investment and firm heterogeneity, Working Paper Series 2390, European Central Bank.

Ewens, M., Peters, R. H. and Wang, S. (2019), Measuring Intangible Capital with Market Prices, NBER Working Papers 25960, National Bureau of Economic Research, Inc.

Hoberg, G. and Maksimovic, V. (2015), 'Redefining Financial Constraints: A Text-Based Analysis', The Review of Financial Studies 28(5), 1312-1352.

Joseph, A., Kneer, C., van Horen, N. and Saleheen, J. (2019), All you need is cash: corporate cash holdings and investment after the financial crisis, Bank of England working papers 843, Bank of England.

Kalemli-Ozcan, S., Laeven, L. and Moreno, D. (2019), Debt overhang, rollover risk, and corporate investment: evidence from the European crisis, Working Paper Series 2241, European Central Bank. 
Melcangi, D. (2019), Firms' Precautionary Savings and Employment during a Credit Crisis, Staff Reports 904, Federal Reserve Bank of New York. 